\title{
واقع تصفح واستخدام المواقع الإكترونية من قبل طلبة قسم الصحافة والإعلام في جامعة البتراء
}

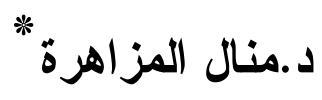

مقدمة: - مقا

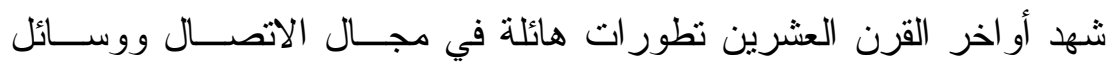

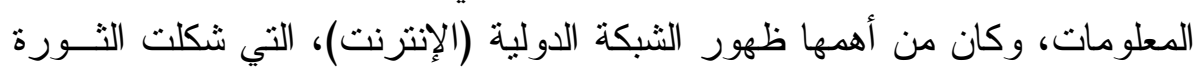

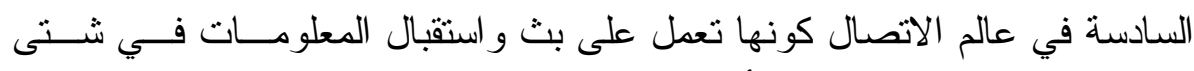

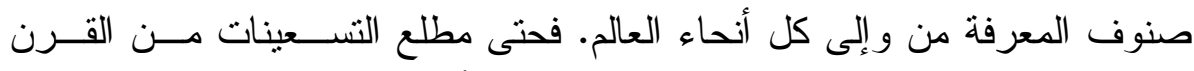

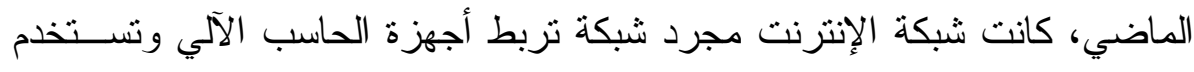

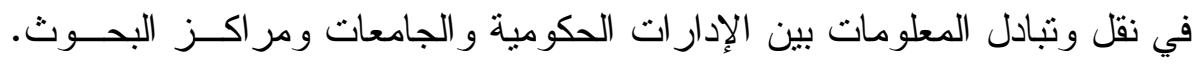

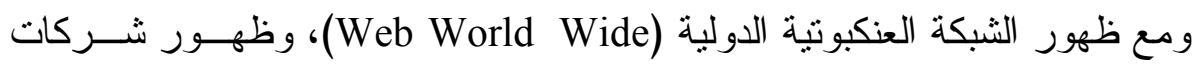

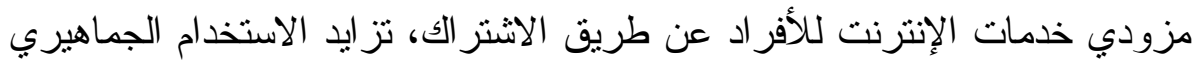

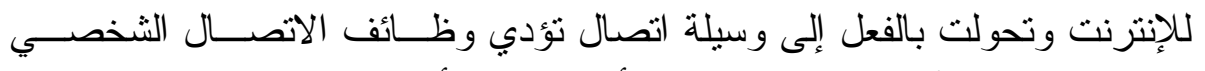

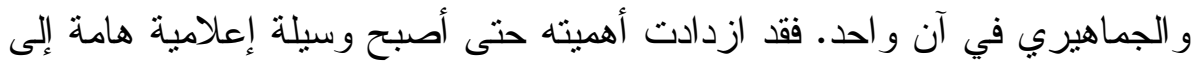

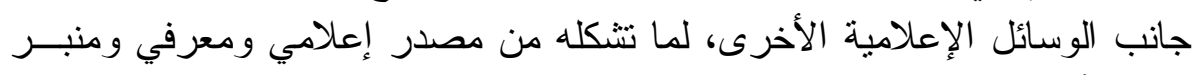

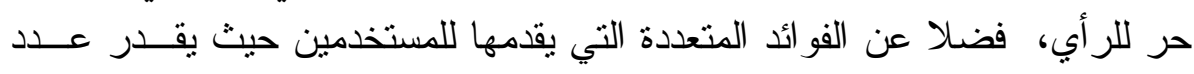

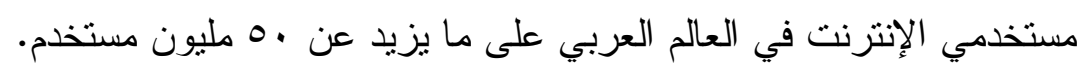

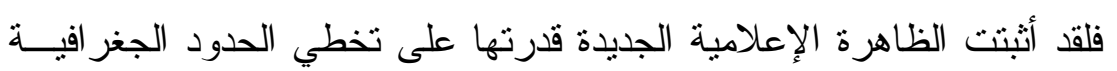

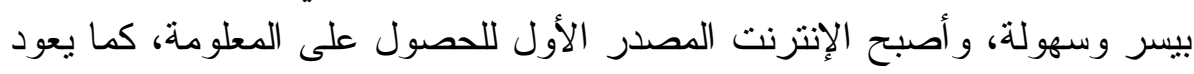

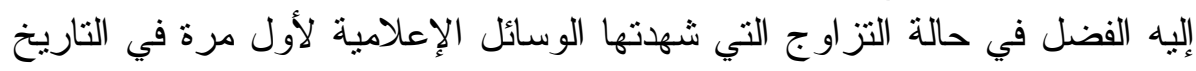

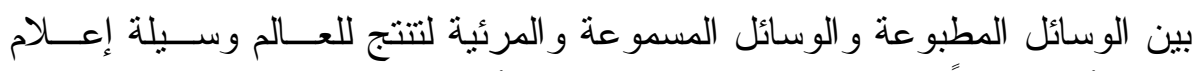

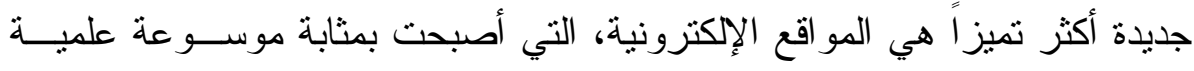

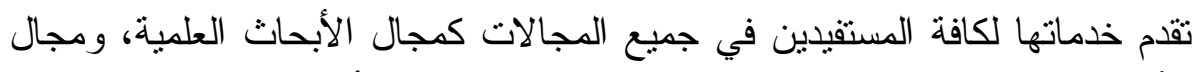

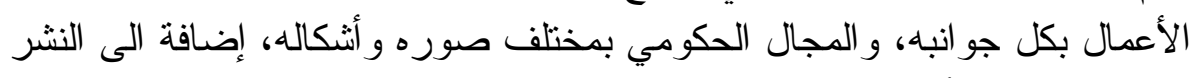

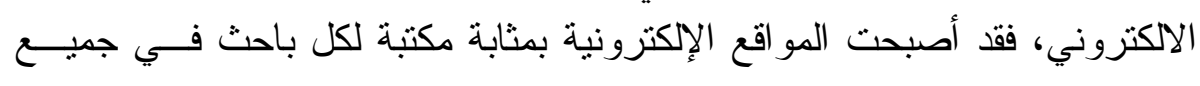

* أستاذ مساعد قسم الصحافة والإعلام كلية الآداب والعلوم جامعة البترا. 


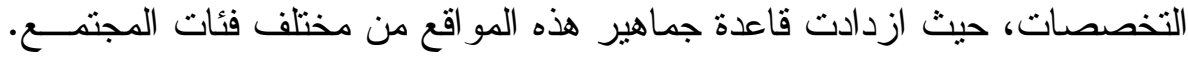

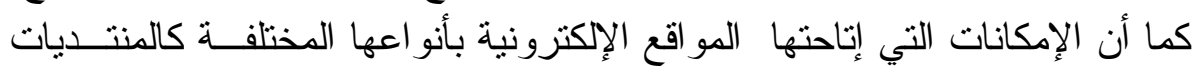

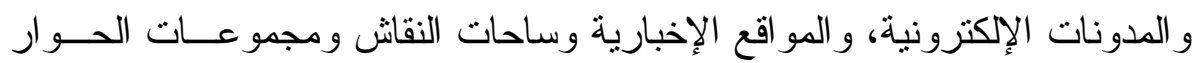

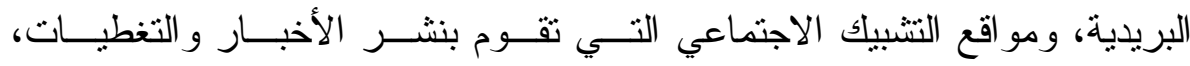
و التحليلات و الآر اء و الموضو عات المختلفة وتبادل المعلومات بين مرتاديها شكلت

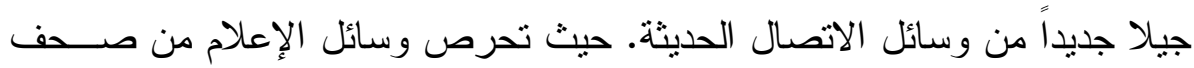

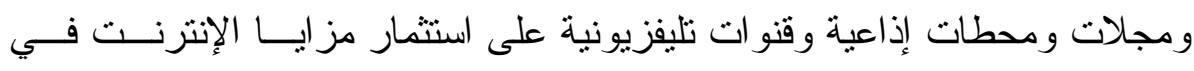

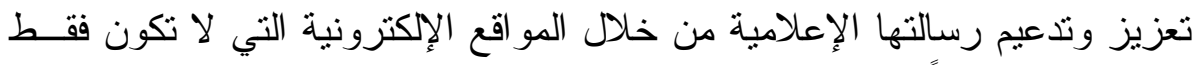

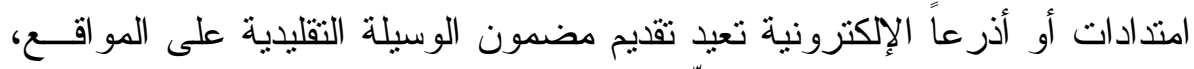

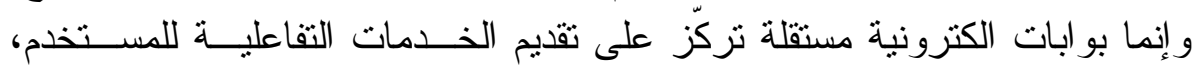

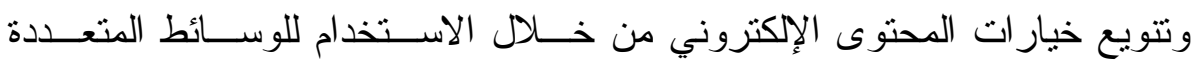
كالنص، و الصور ، و الصوت، و الفيديو ، والرسوم متحركة، إضــــافة

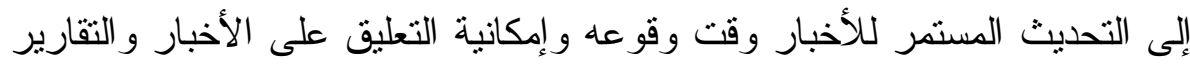
المنشورة.

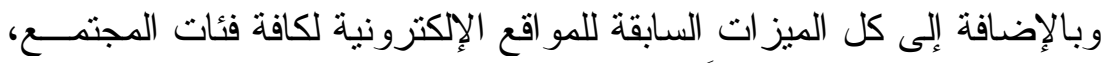

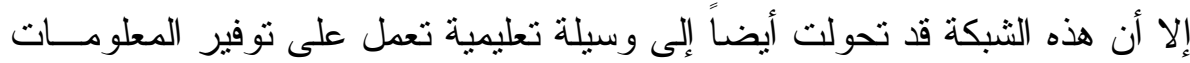

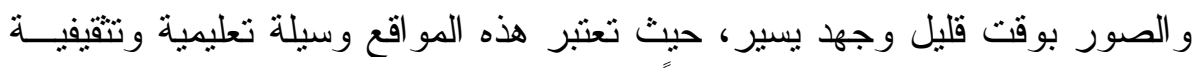

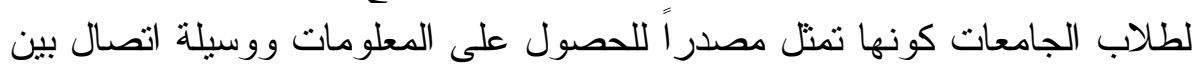

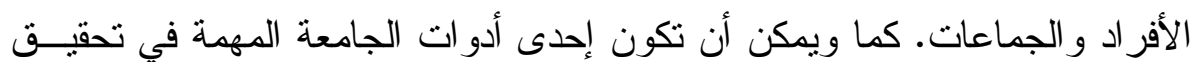

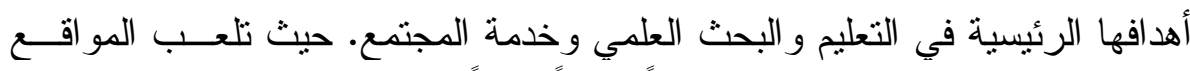

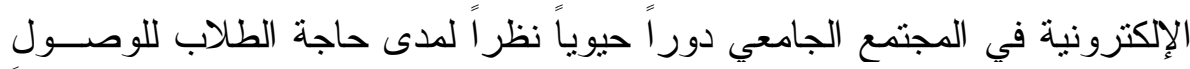

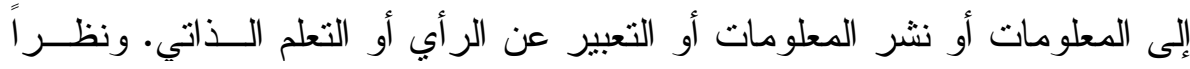

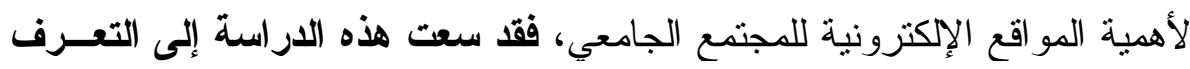

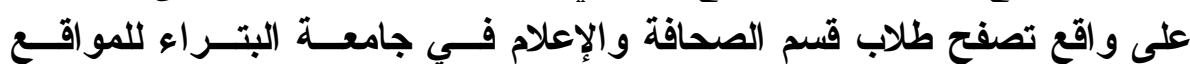

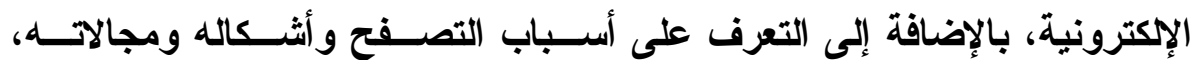

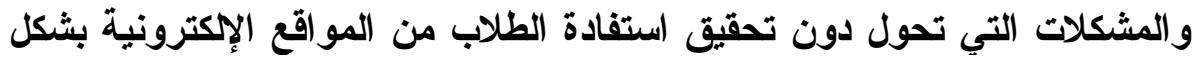

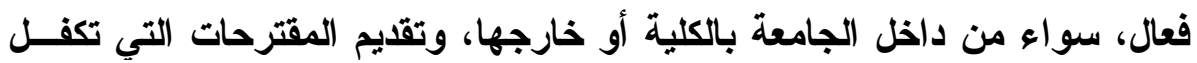
رفع نسبة التصفح وزيادة فعاليته. 


\section{أولاً: مشكلة الدر اسة:}

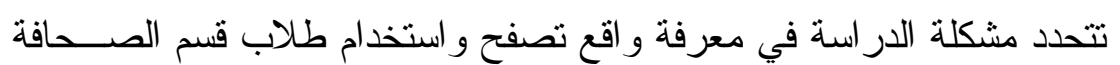

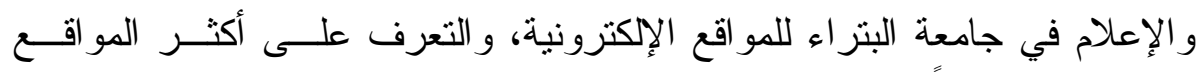

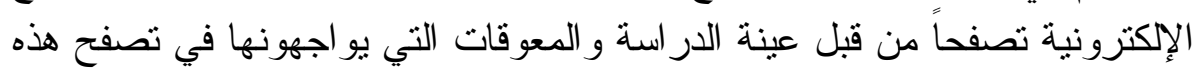
المو اقع من مختبر ات الجامعة.

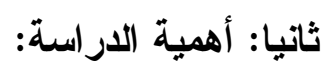

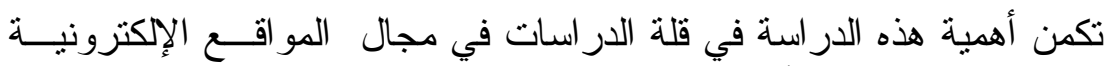

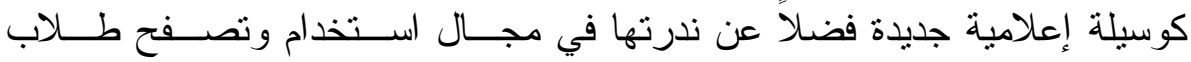

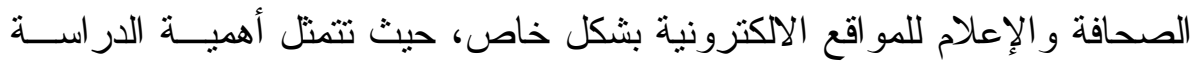
الحالية في عدة محاور وهي كما يلي:

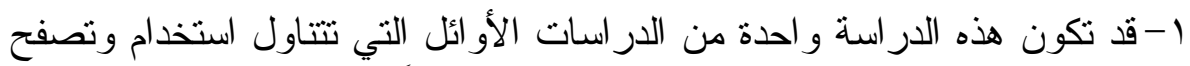

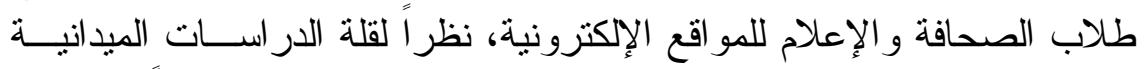

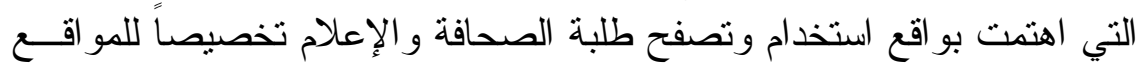

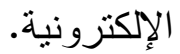

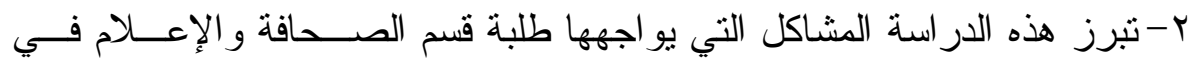

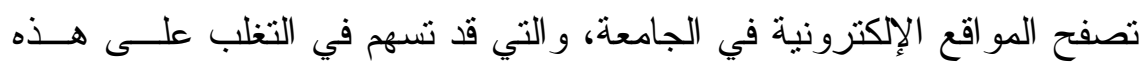

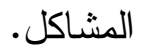

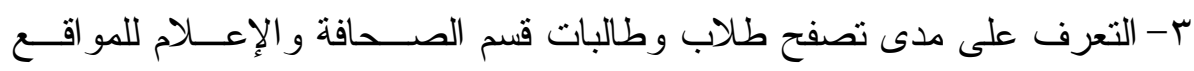
الإلكترونية وطبيعة هذا التصفح.

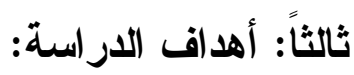

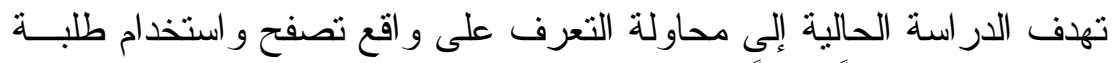

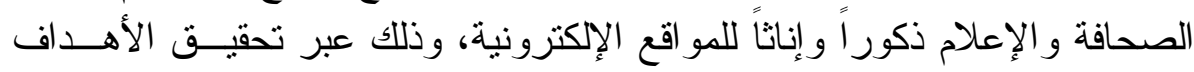

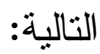
1- التعرف على دو افع تصفح المو اقع الإلكترونية. r- التعرف على أي المو اقع الإلكترونية أكثر تصفحاً.

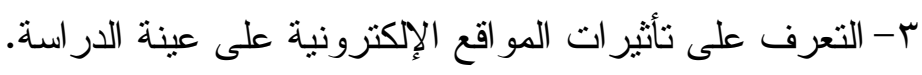




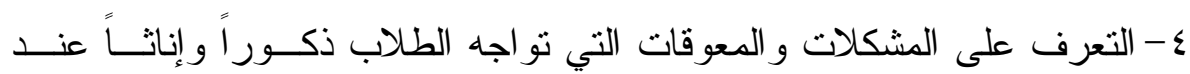

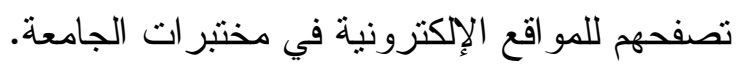

رابعاً: الدر اسات السابقة:

يعتبر الإنترنت و المو اقع الإككترونية من المو اضيع التي لاقت اهتماماً كبيــراً

من قبل الباحثين، فقد تتوعت وتعددت الدراسات التي تعلقت بهذه الوسيلة الاتصالية

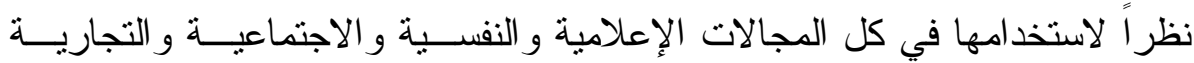

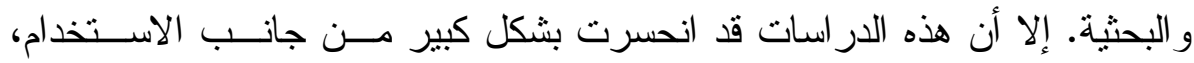

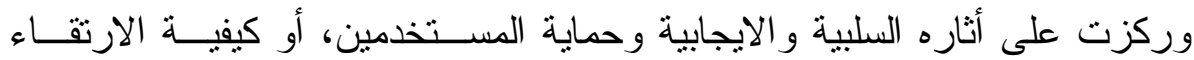
بفعالية الاستخدام. فمن وجهة نظر الباحثين في علم المكتبات و المعلومــات يعتبــر

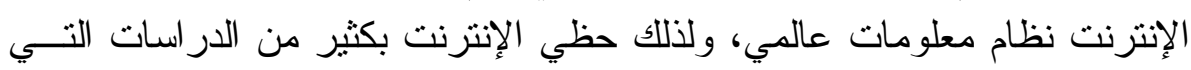

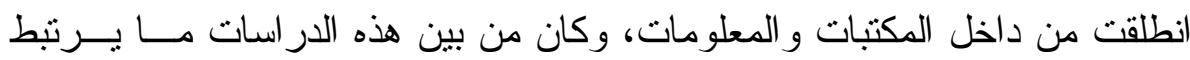

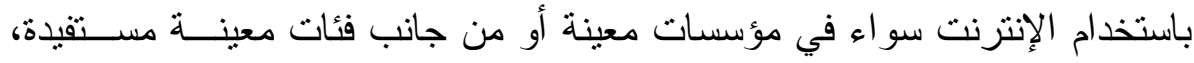

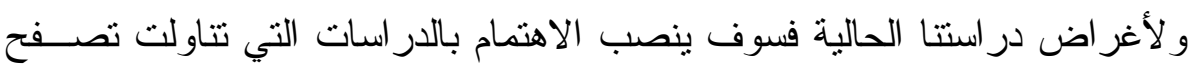
الإنترنت في الجامعات على المستوى العربي و المستوى الأجنبي.

$$
\text { أ) الار اسات العربية: - الإنزية }
$$

- دراسة ميساء رشيد حول استخدامات الشباب الجامعي للصحافة الإكترونيـة

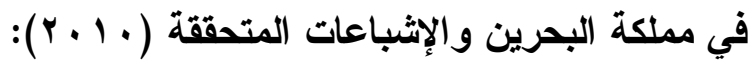

هدفت هذه الدر اسة إلى معرفة مدى تعرض الثباب الجــامعي فــي مملكـــة

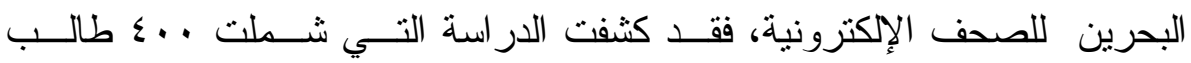

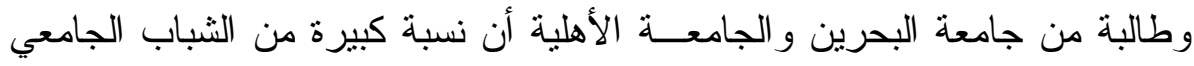

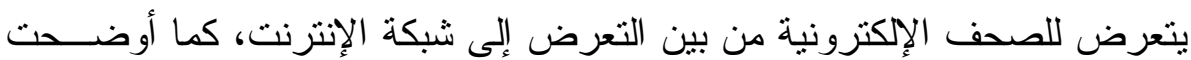

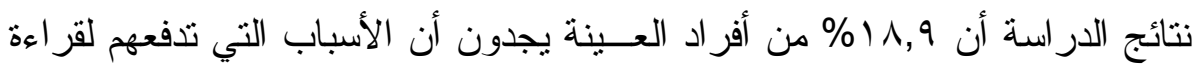

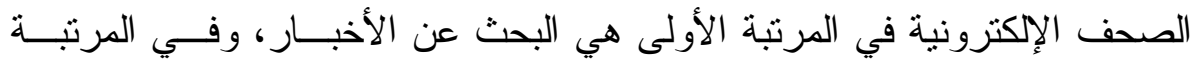

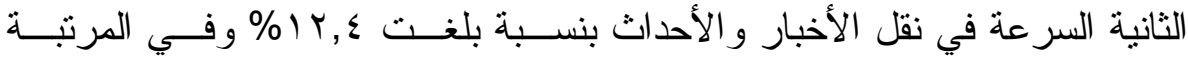

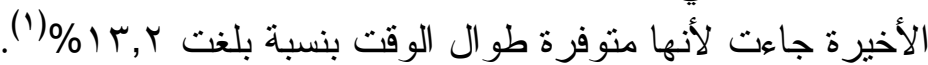
- دراسة أمين أبو وردة حول متابعة طلاب جامعة النجاح في فلسطين للمواقــع

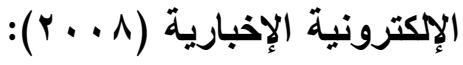




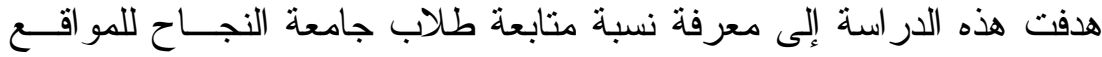
الإلكترونية، حيث بينت نتائج الدر اسة أن المو اقع الإككترونية الفلسطينية تؤثر بشكل فئل

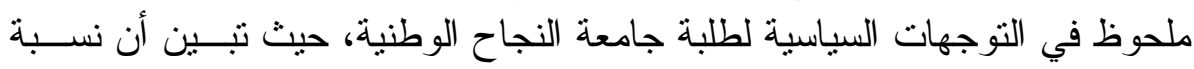

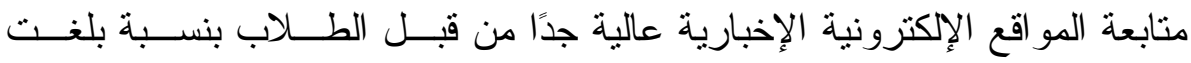

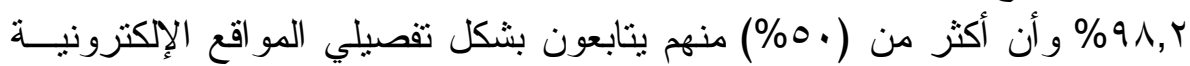

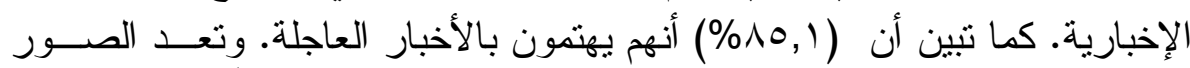

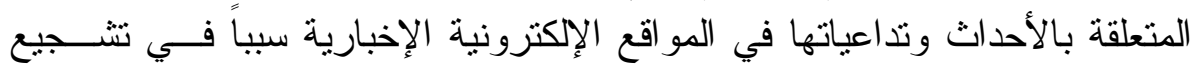

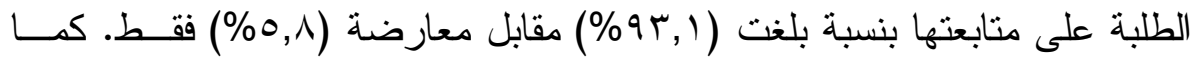

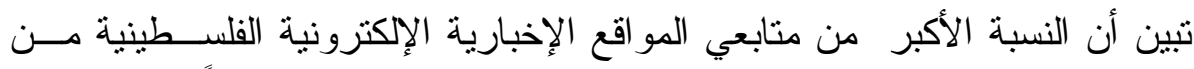

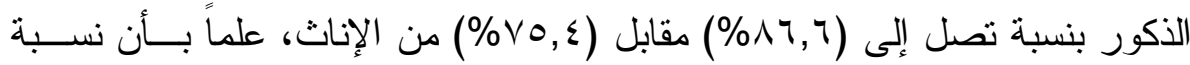

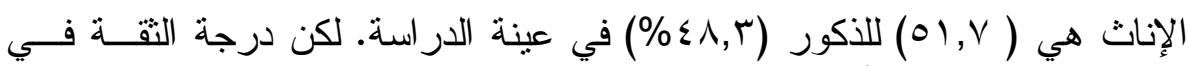

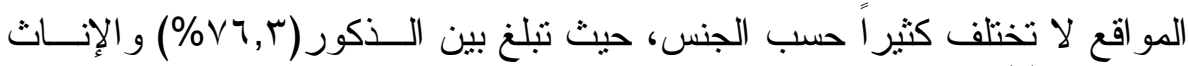
. ${ }^{(r)}(\% \vee \vee, r)$

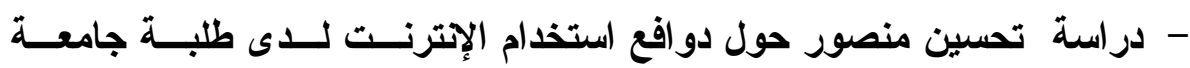

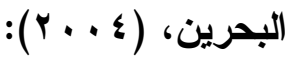

هدفت هذه الدر اسة للكثثف عن دو افع استخدام الإنترنت لدى عينة من طلبــة

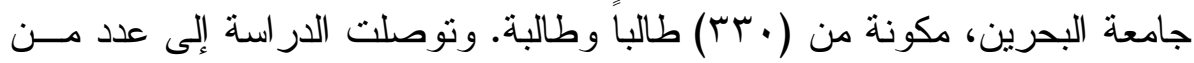

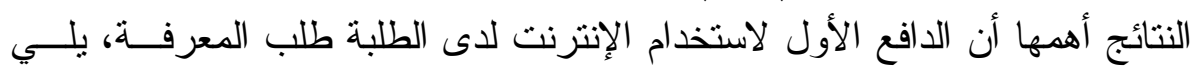

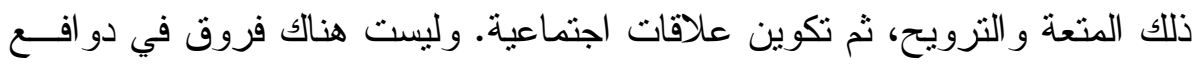

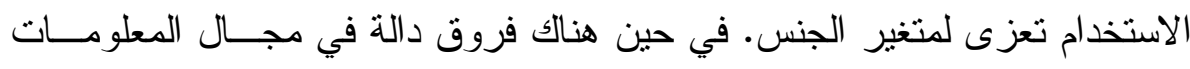

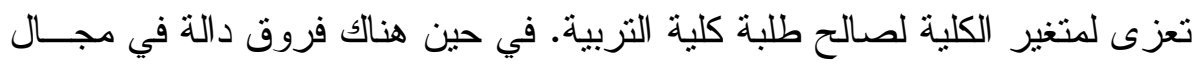

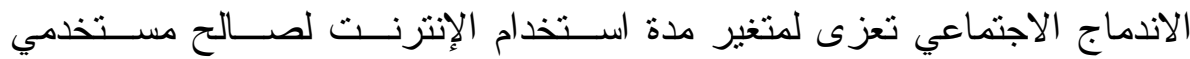

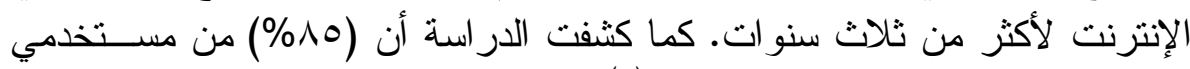
الإنترنت ر اضون عن نتائج استخدامهم (َّ).

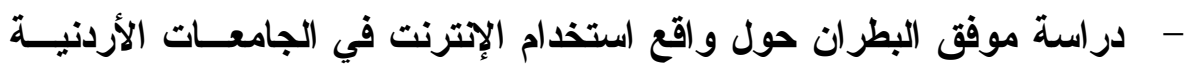

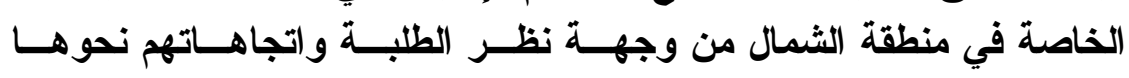
$:(r, r)$

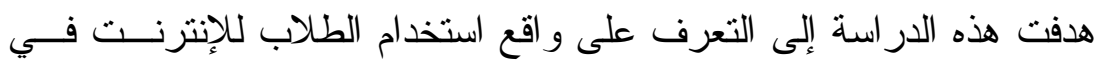

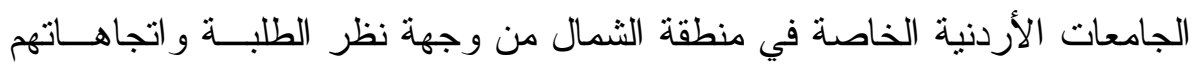


نحوها. وقد استخدم الباحث المنهج الوصفي التحليلي، وتكونت عينة الدراسة مسن التسن جامعة جرث VOr

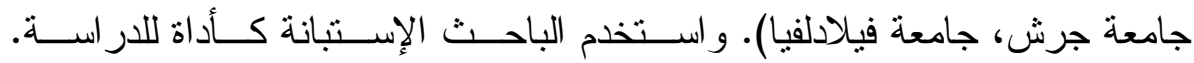

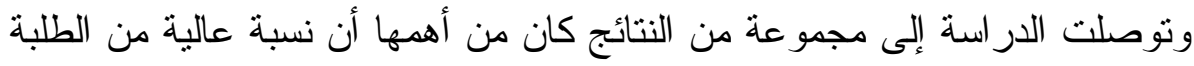

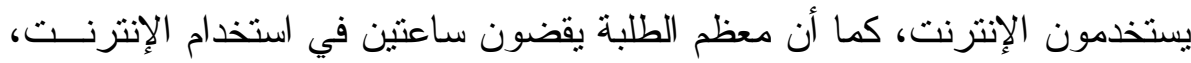

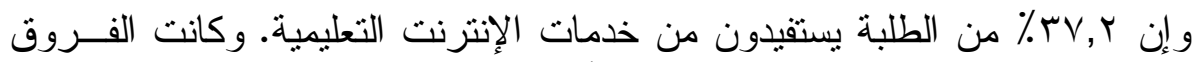

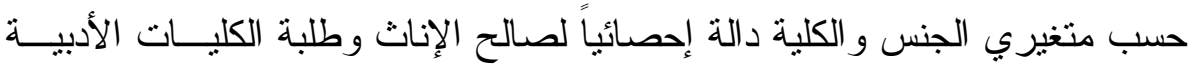

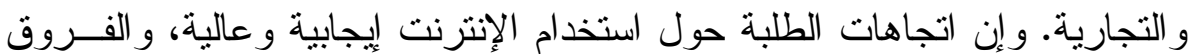

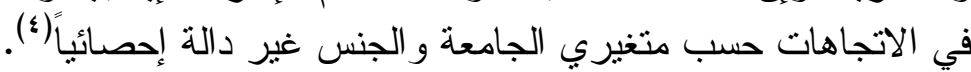

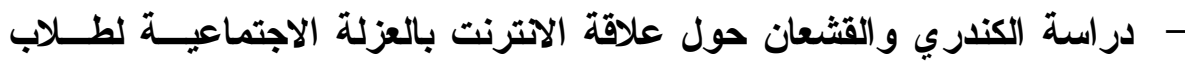

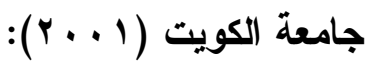

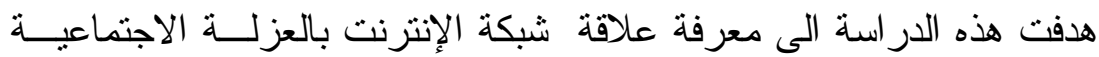

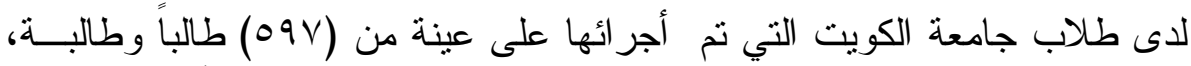

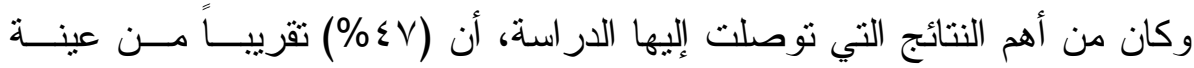

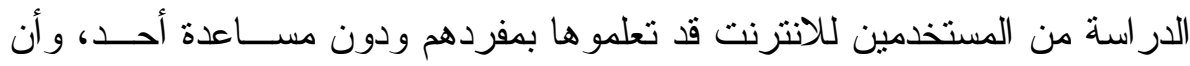

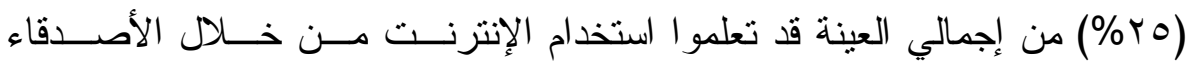

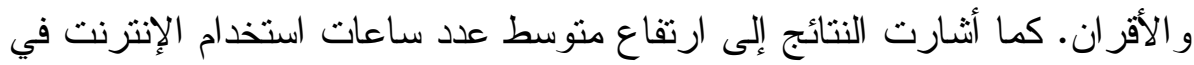

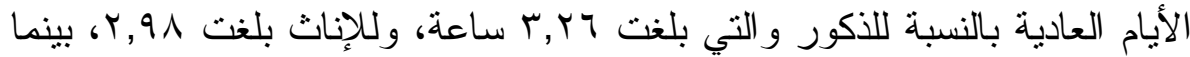

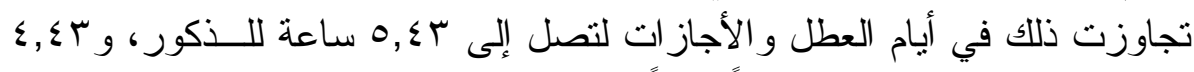

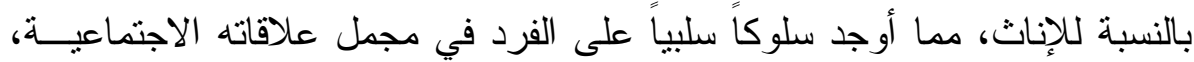

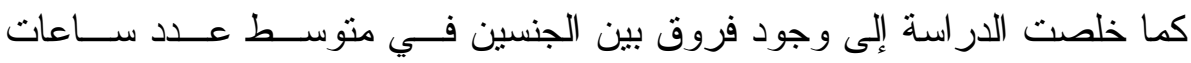

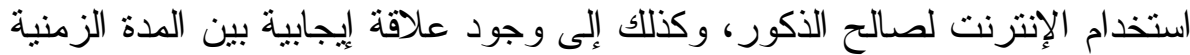
لاستخدام الإنترنت وبين العزلة الاجتماعية (ه).

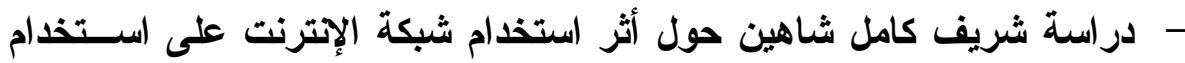

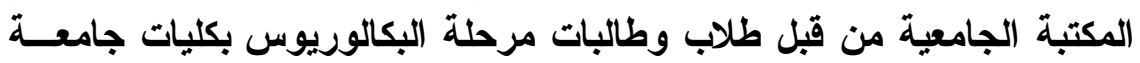

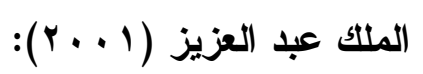

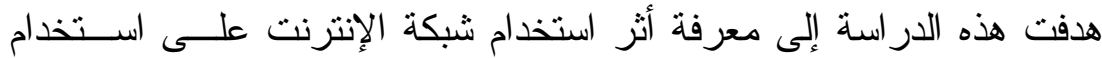

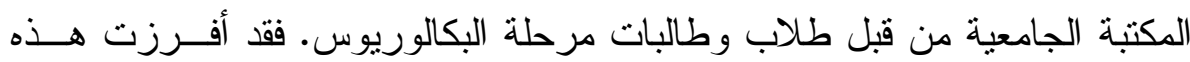

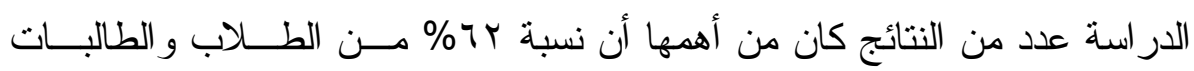




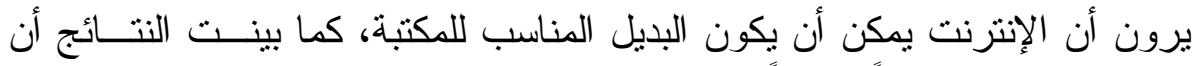

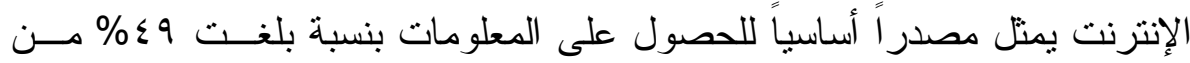

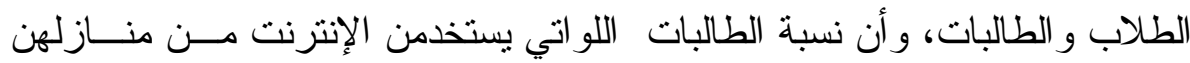

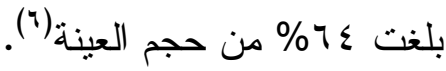

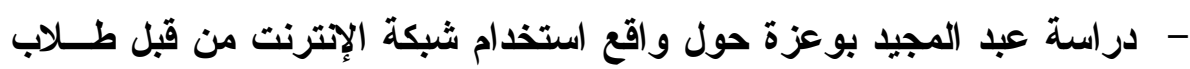

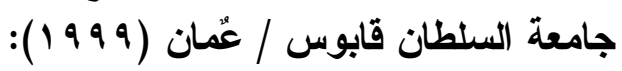

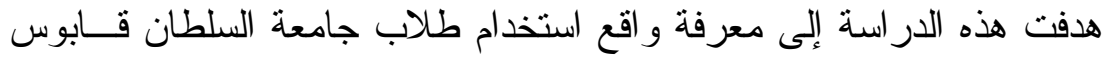

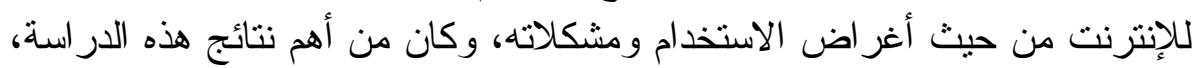

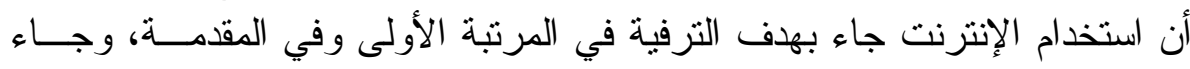

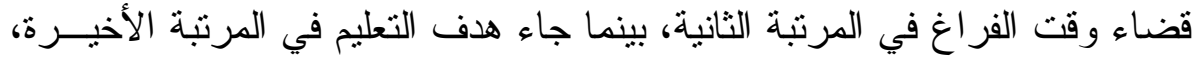

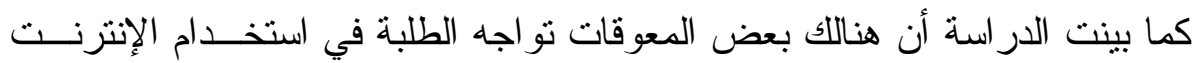

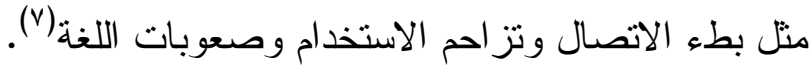

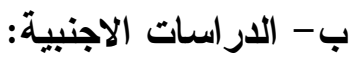

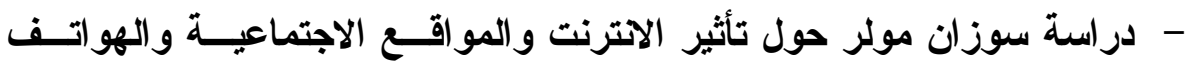

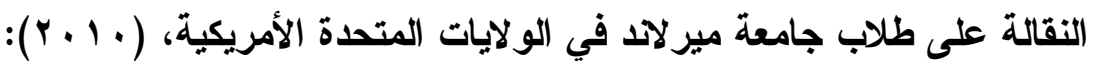

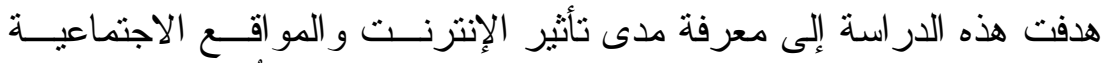

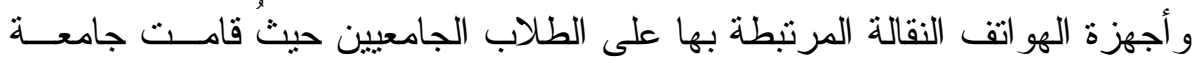

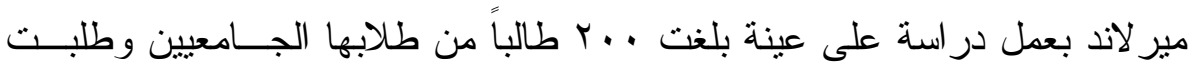

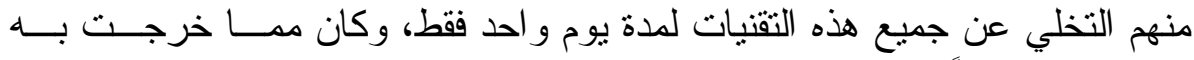

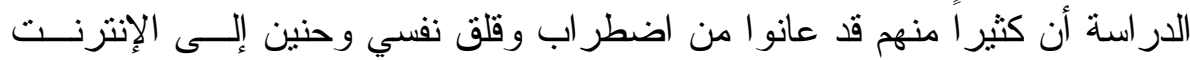

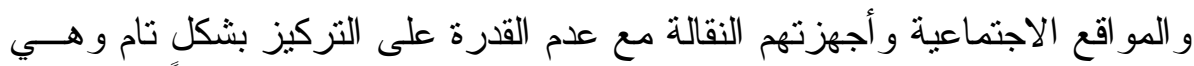

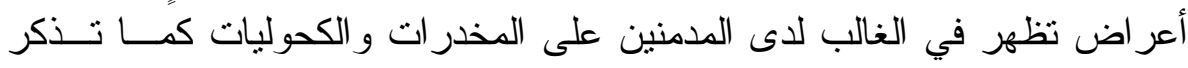

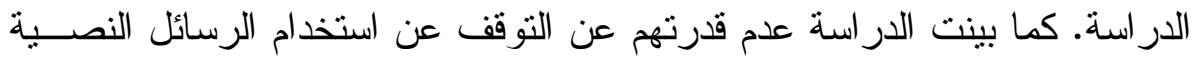

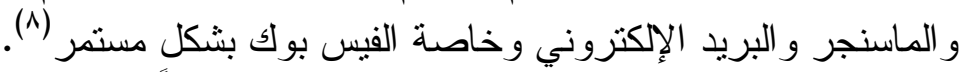

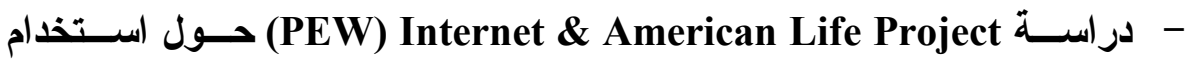

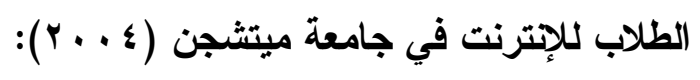

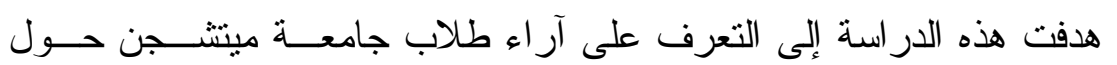

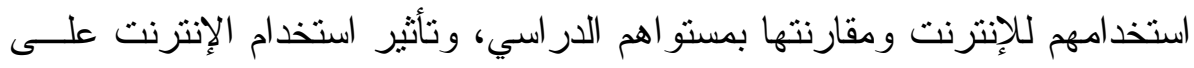




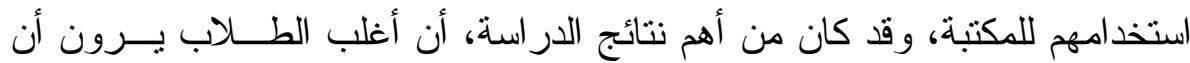

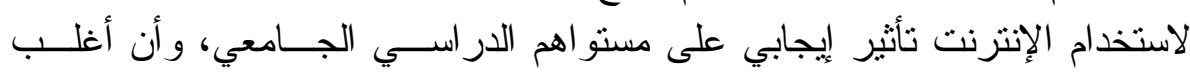

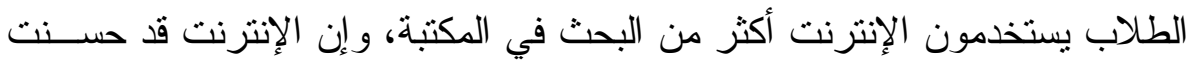

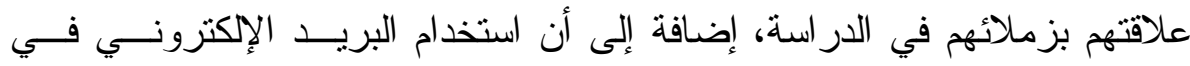

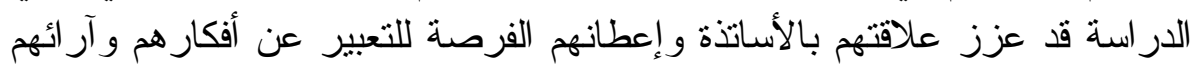

الني وجدو اصعوبة في التعبير عنها في الددرجات (9).

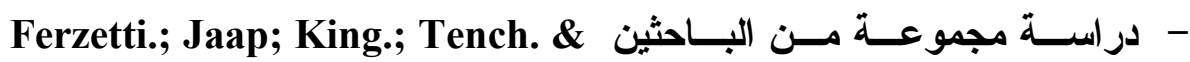
Thomas، حول تأثير استخذام الاتترنت على طلاب جامعة بنســلفاتيا، لعسام

$$
\text { : Y.. }
$$

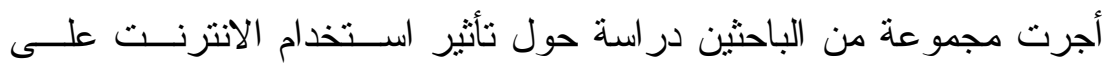

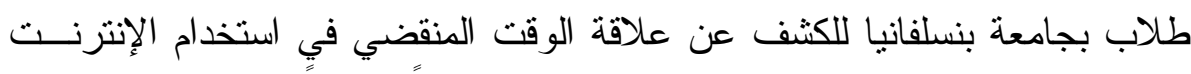

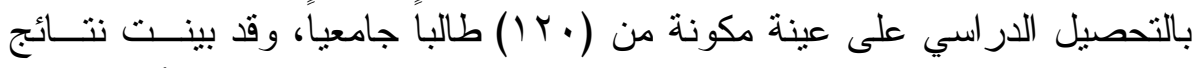

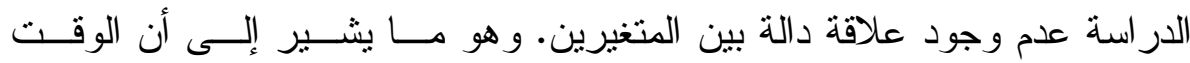

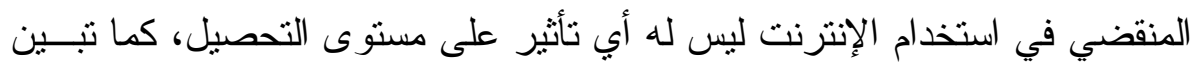

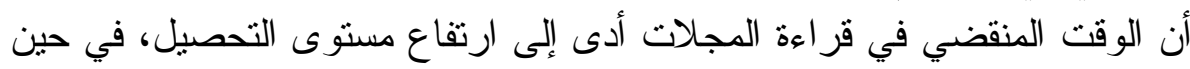

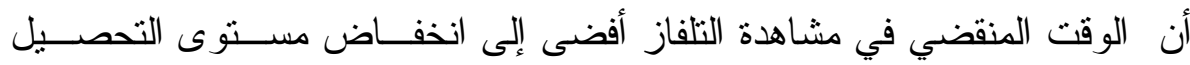

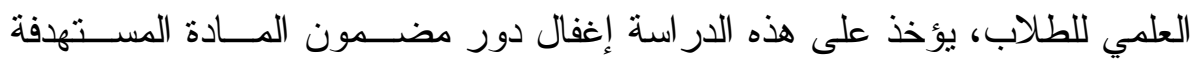

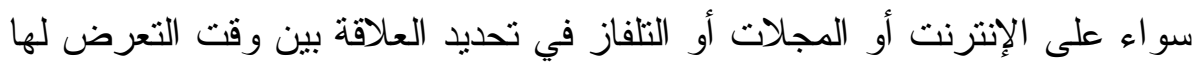

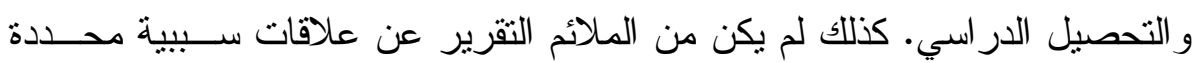

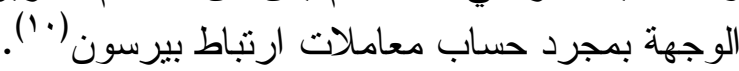

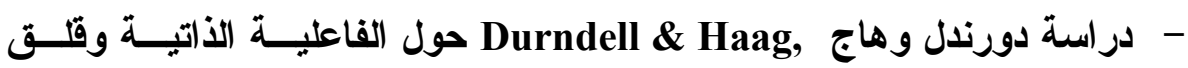

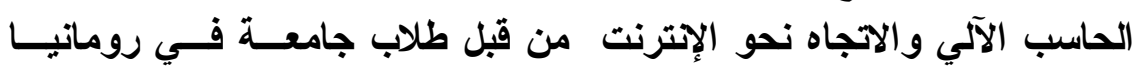

$$
\text { : (r...r) }
$$

هدفت هذه الدراسة إلى معرفة مدى تأثير كل من الفاعلية الذاتية و القلق مسنِ

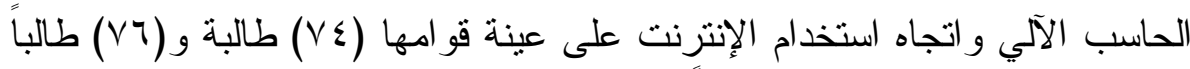

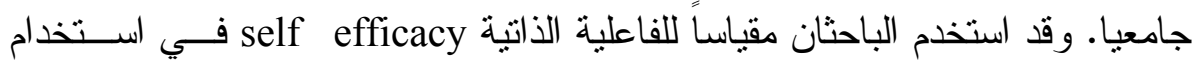

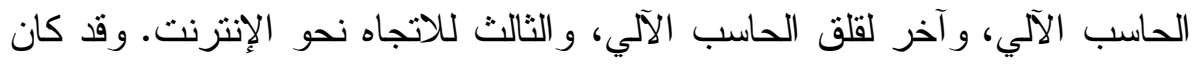

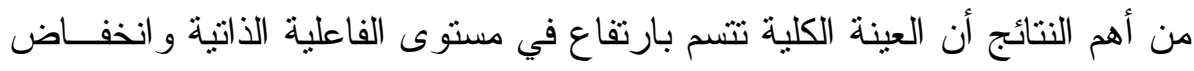
في كل من قلق الحاسب والاتجاه التفضيلي نحو الإنترنت. وأن الذكور أكثر فاعلية 
ذاتية و أقل قلقاً، واتجاهاتهم نحو الإنترنت أكثر إيجابيـة مقارنــة بالإنــاث. كــــا

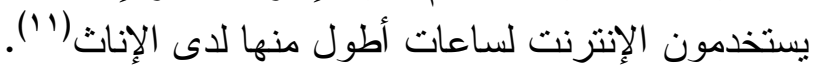

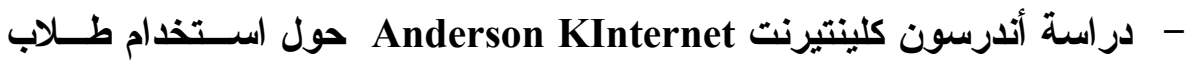

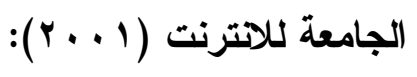

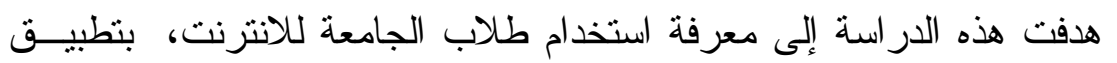

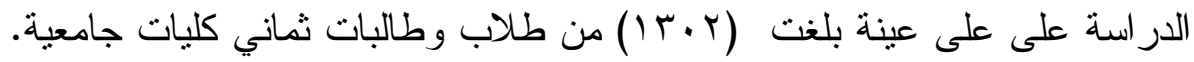

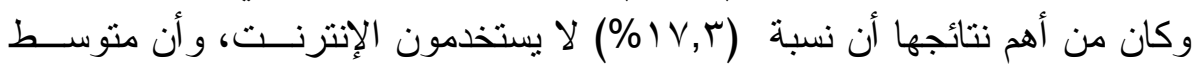

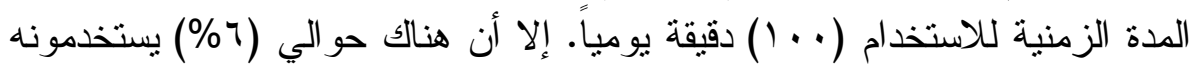

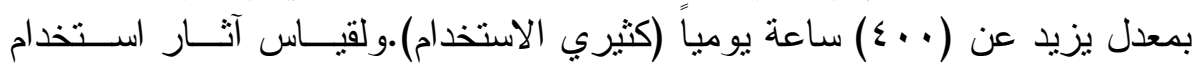

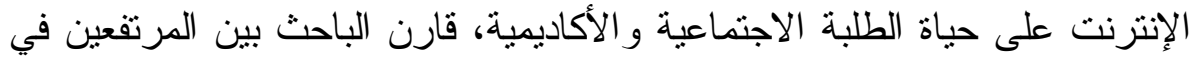

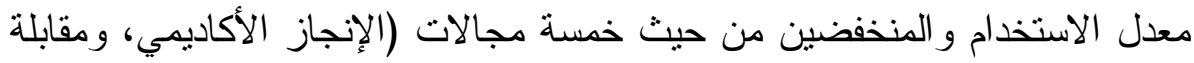

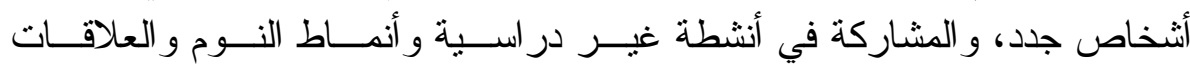

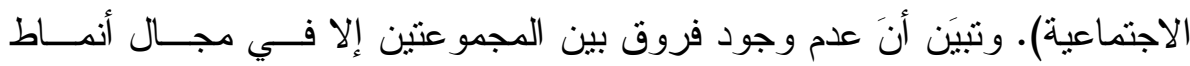

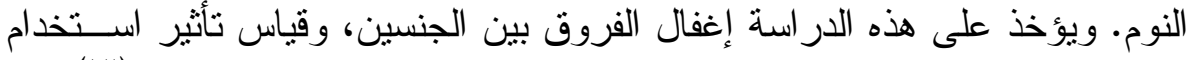

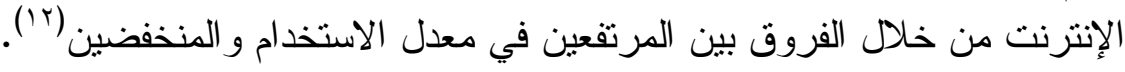

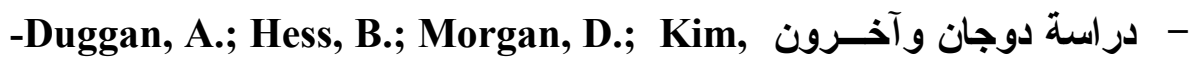
Sول S. \& Wilson

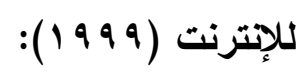

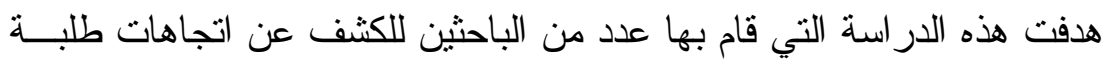

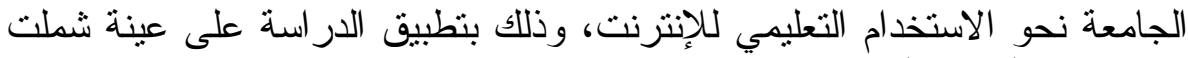

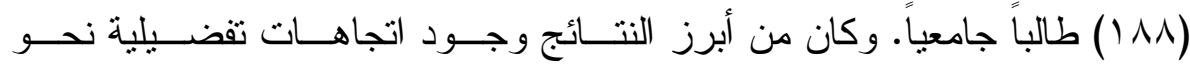

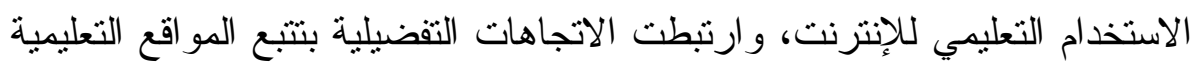

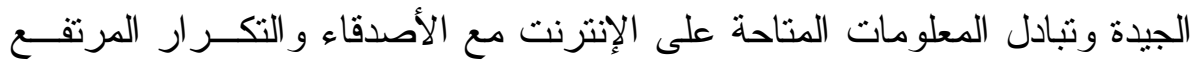

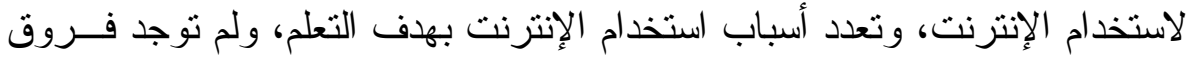

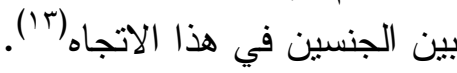

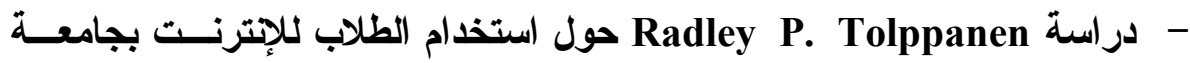

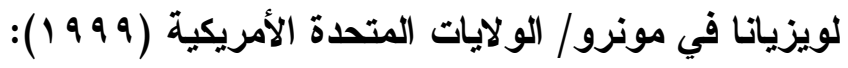




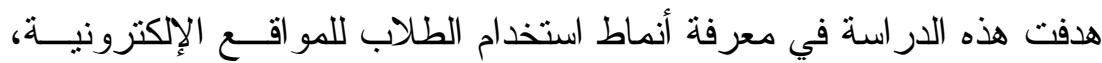

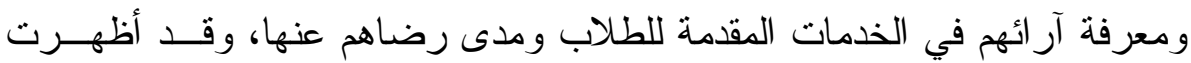

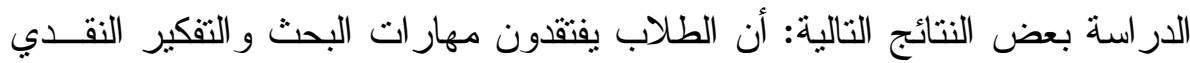

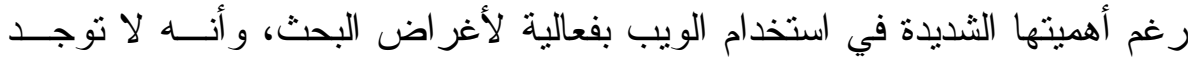

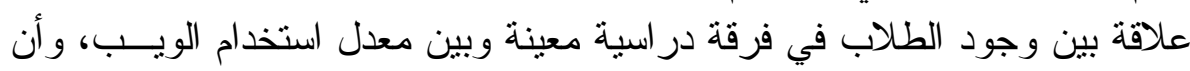

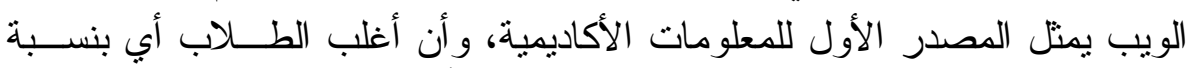

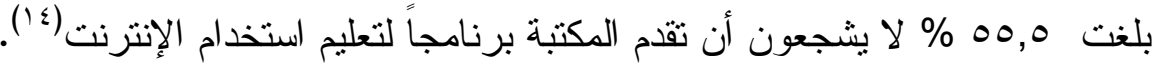
- دراسة تيموثى بيرى Timothy T. Perry وزملائه حول اســتخدام طـلاب

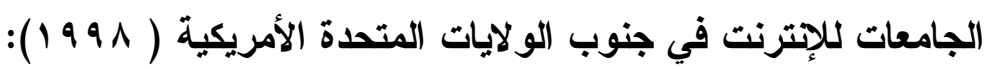

سعت هذه الدر اسة إلى كثف ما إذا كانت هناك اختلافات بين المجموعــات

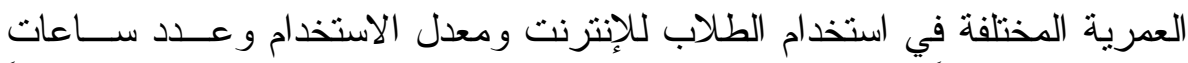

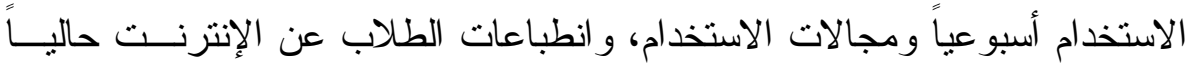

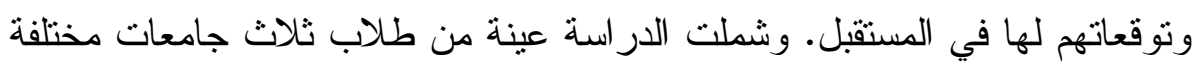

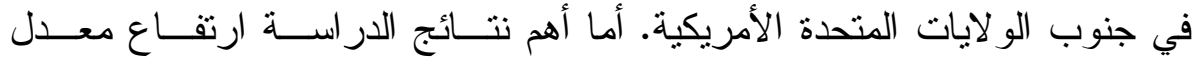

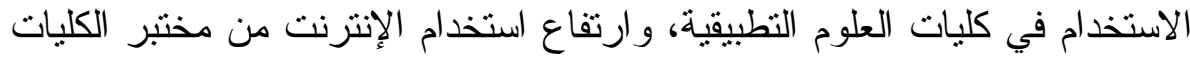

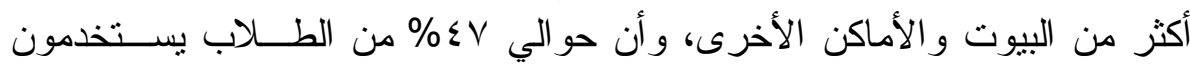

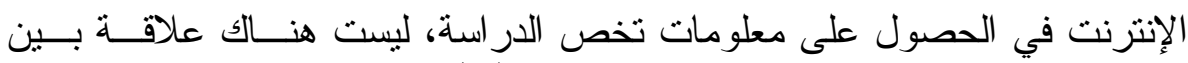

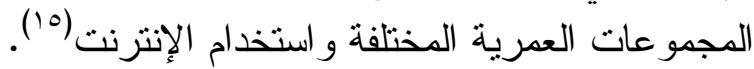

- دراسة فورد وميلر (Ford \& Miller) حول الفروق بين الجنسـين بجامعـة

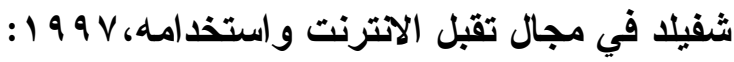

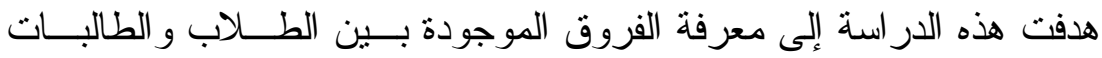

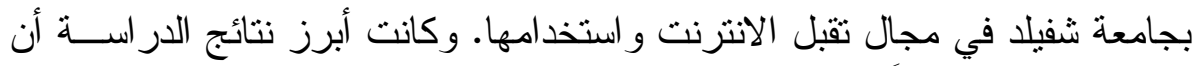

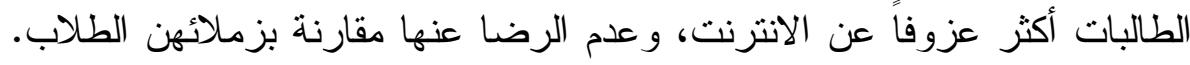

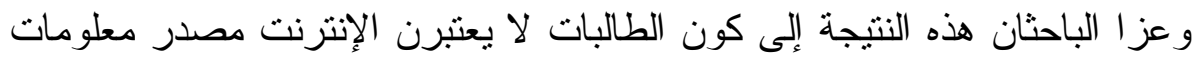

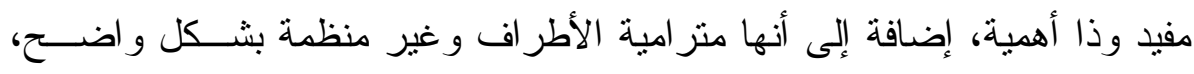

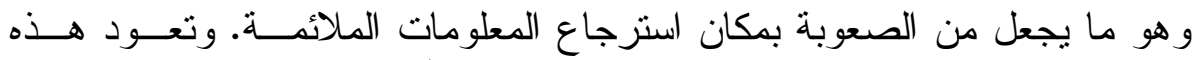

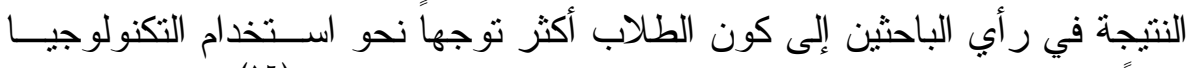

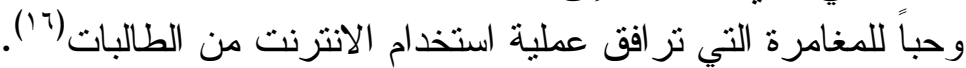


- - دراسة مرفي وباسكوي (Murphy and pascoe) حول اســـذام الطلبـة

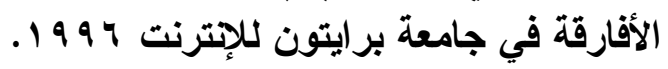

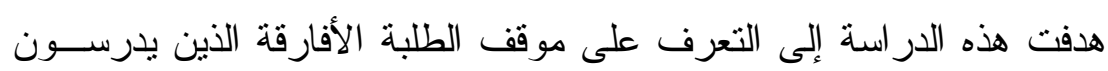

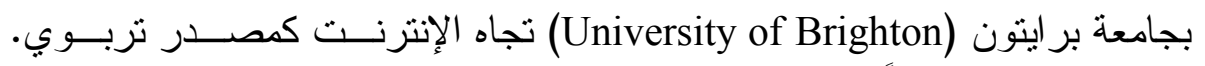

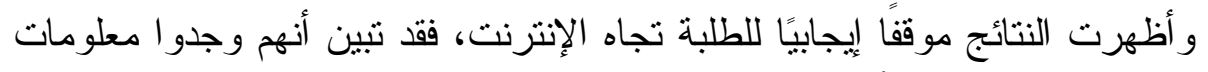

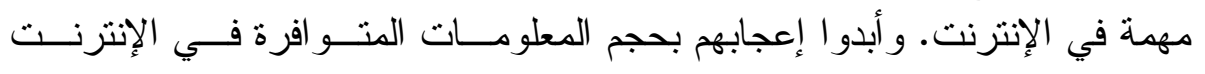

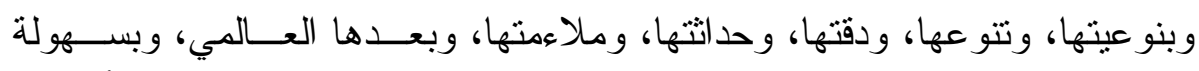

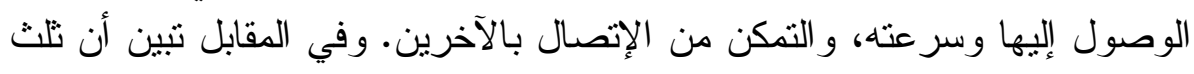

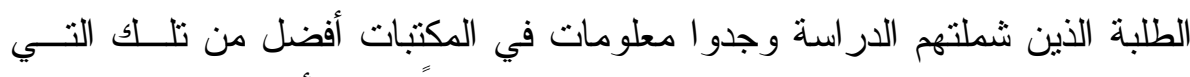

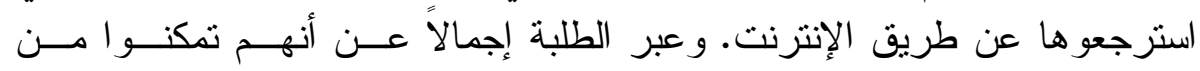

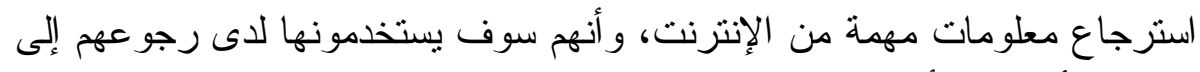

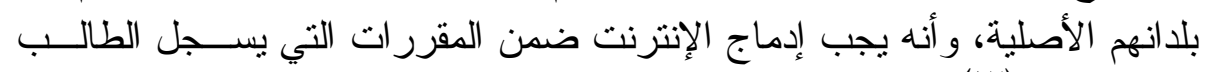
فيها بالجامعة (1V)

\section{- التعليق على الاراسات السابقة:}

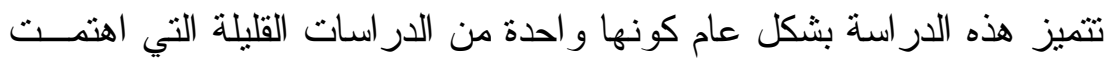

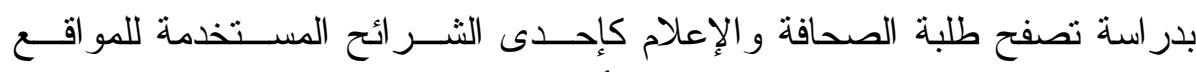

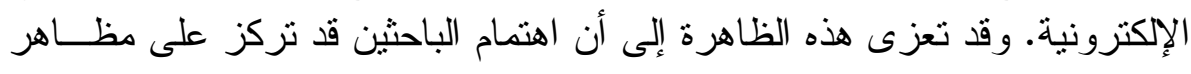

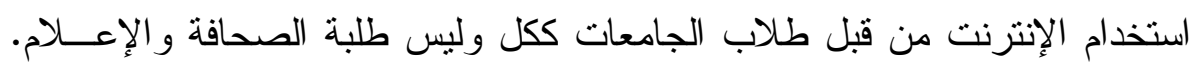

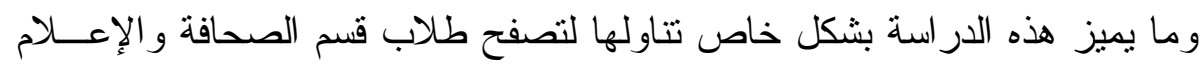
للمو اقع الإكترونية. خامساً: الإطار المنهجي للار اسة: الإنة:

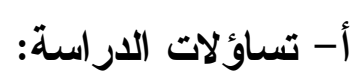

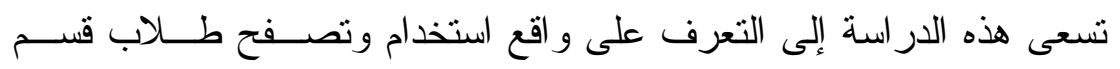

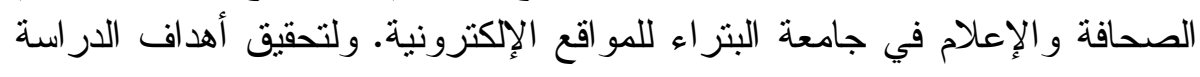

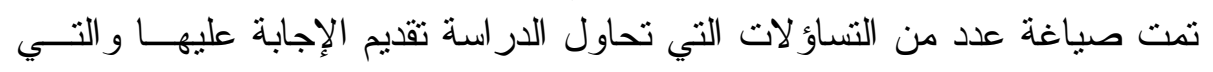

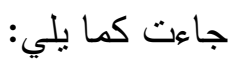


1- ما هي دو افع تصفح و استخدام المو اقع الإلكترونية لدى طلاب قسم الصــافة و الإعلام ذكور أ و إناثًا

r- ما المدة التي يقضيها طلاب الصحافة و الإعلام ذكوراً و إناثاً في تصفح المواقع الإناء الإلكترونية؟

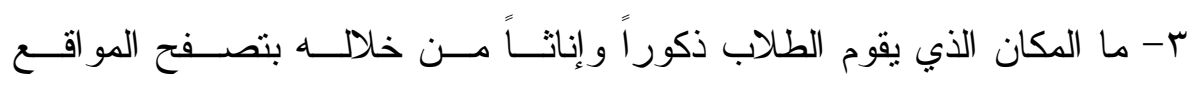
الإلكترونية؟

ع- ما هي المواقع الإلكترونية الأكثر تصفحاً من قبل طلاب الصحافة و الإعــلام ذكوراً و إناثاً

ه-ما مدى اعتبار المو اقعِع الإلكترونية مصدر أ للمعلومات لدى طلاب قسم الصحافة

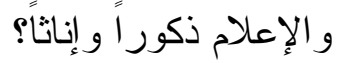

צ- ما مدى نأثير استخدام الطلاب ذكوراً و إناناً المواقع الإلكترونية لفترات طويلة على تحصيلهم الدراسي؟ V- ما مدى نأثير استخدام الطلاب ذكوراً و إناثاً للمواقع الإلكترونية على علاقاتهم الاجتماعية؟

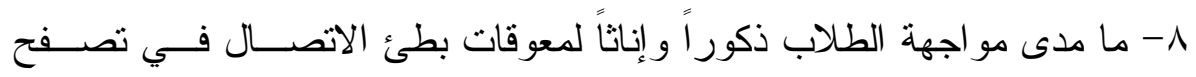

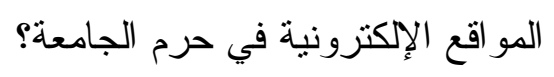

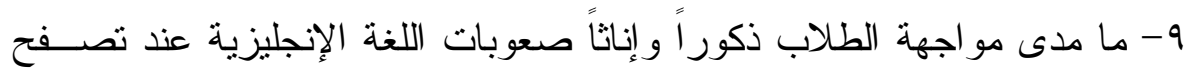

بعض المو اقع الإلكترونيةج

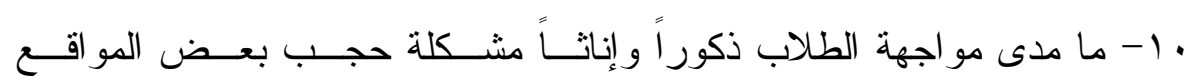

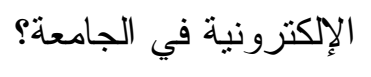

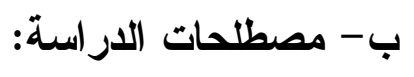

$$
\text { - }
$$

r - استخدام

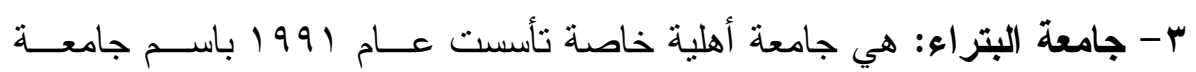

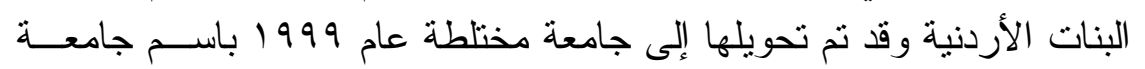

البنراء، وتضم الجامعة خمسة كليات رئيسية هي كلية الصيدلة، العلوم الإدارية 


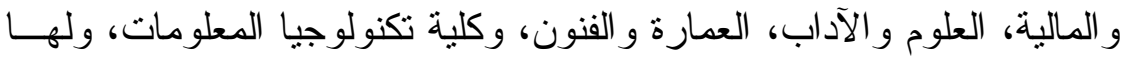

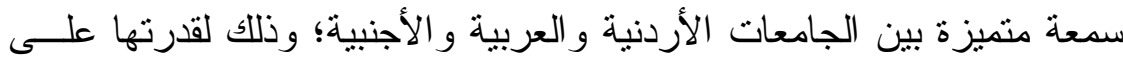

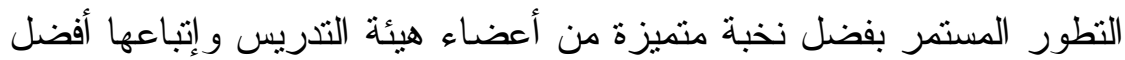

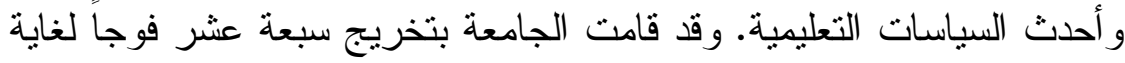

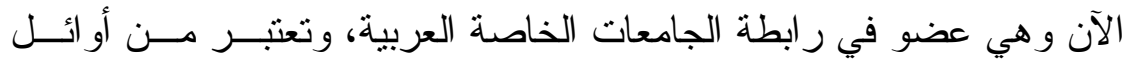

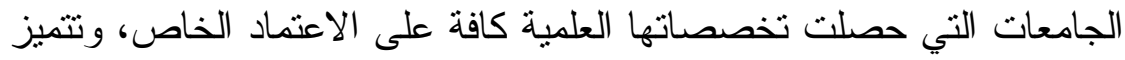

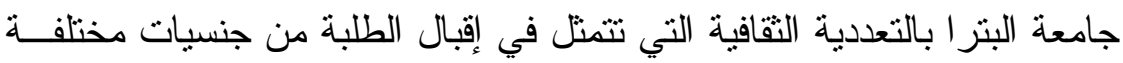
بلغ مجمو عها ثلاثثن جنسية عربية وأجنبية.

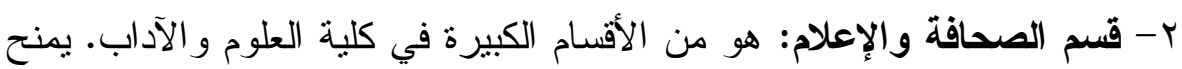

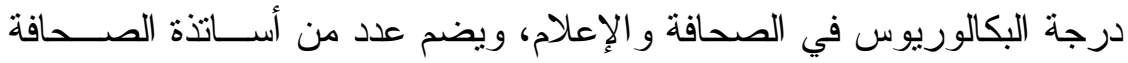

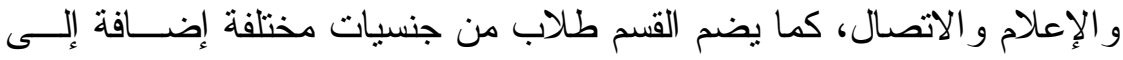
الطلاب من الجنسية الأردنية.

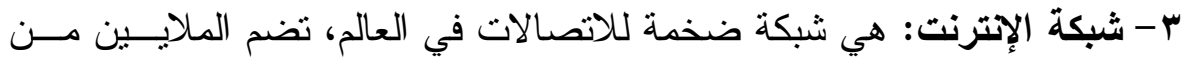

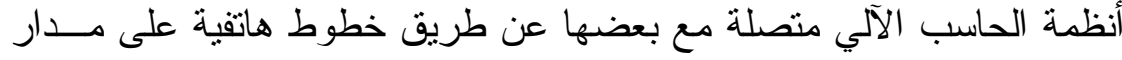

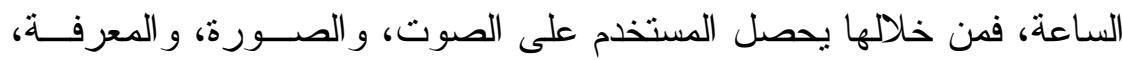

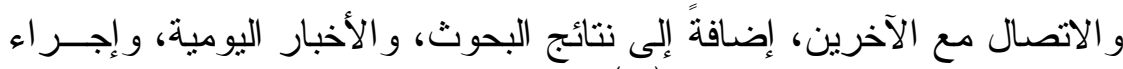

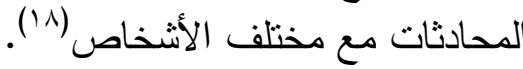

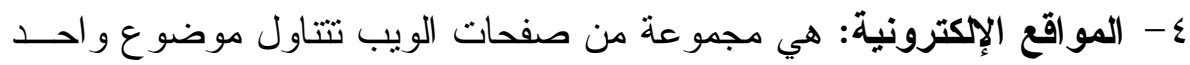

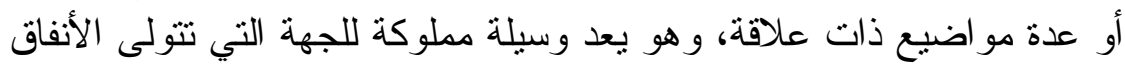

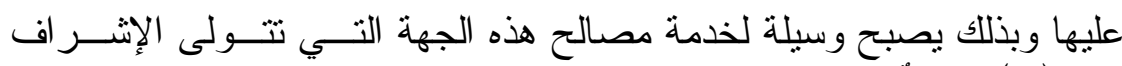

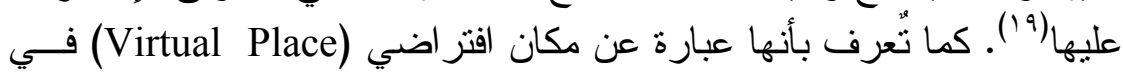

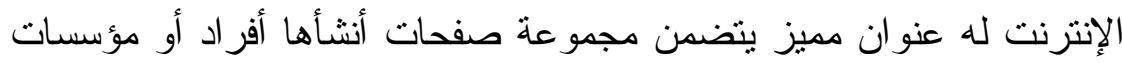
لتكون متاحة عن طريق شبكة الإنترنت (r.).

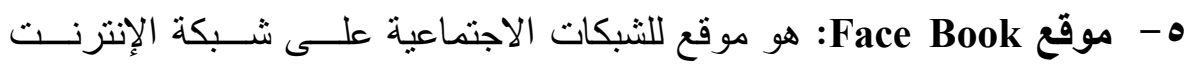

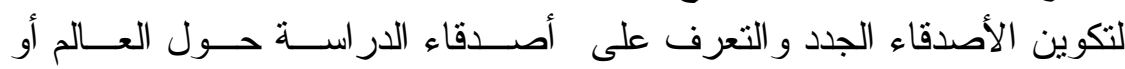

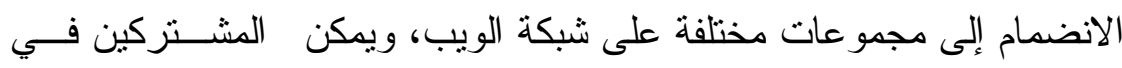

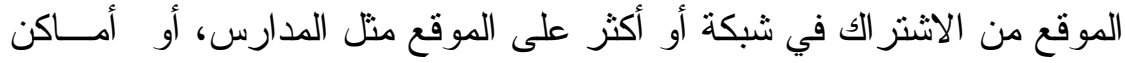

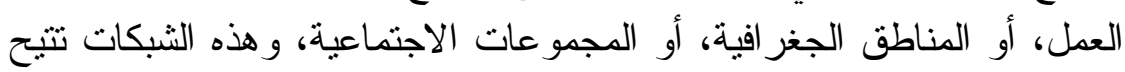




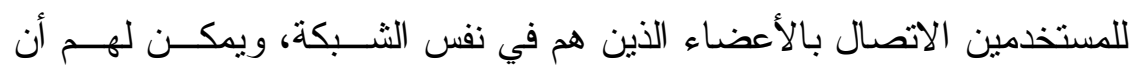

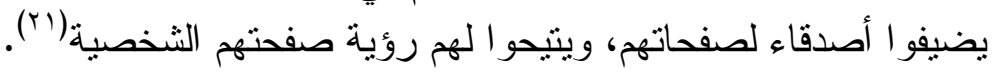

$$
\text { ج- مبررات الاراسة: }
$$

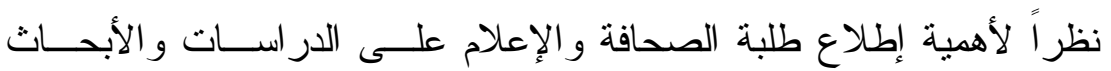

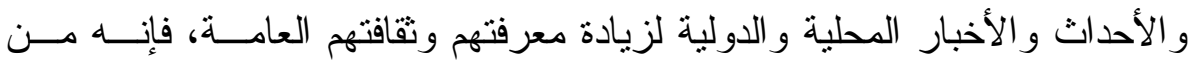

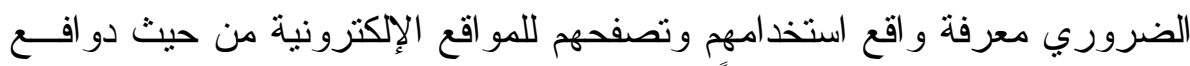

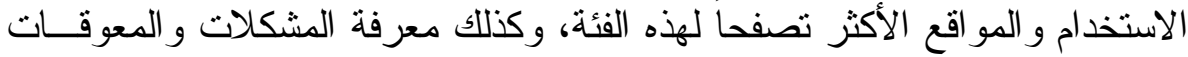

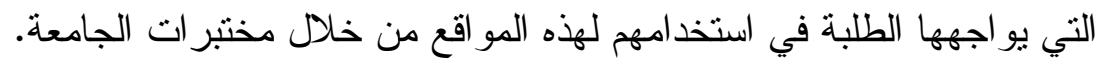
د - الإجراءات المنهجية:

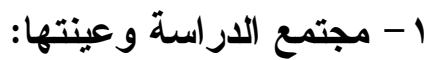

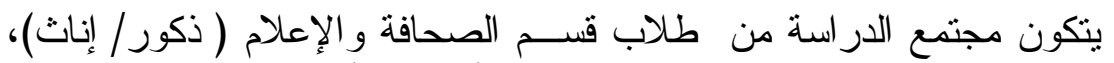

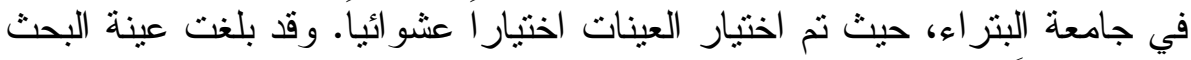

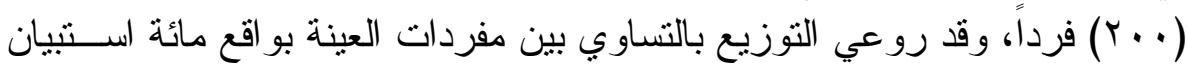

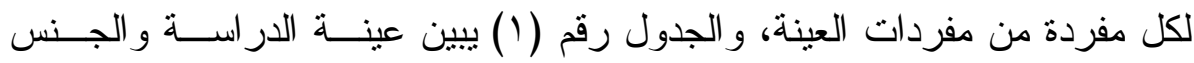

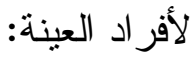

(1) - الجدول رقم

\begin{tabular}{|c|c|c|c|}
\hline النسبة المئوية & التكرار & | الجنس & المفردة \\
\hline$\% 0$. & $1 \ldots$ & ذكر & طلاب \\
\hline$\% \circ$. & $1 \ldots$ & أنثى & طالبات \\
\hline$\% 1 \ldots$ & r... & & المجموع \\
\hline
\end{tabular}

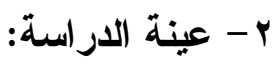

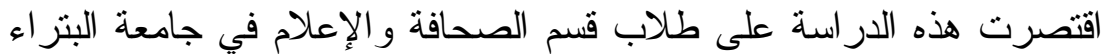

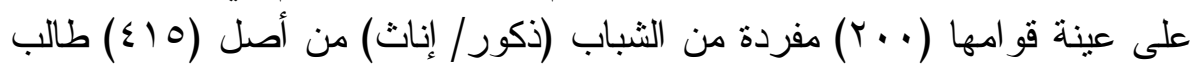

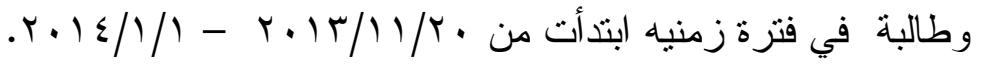




\section{r- أدوات جمع وتحليل البيانات:}

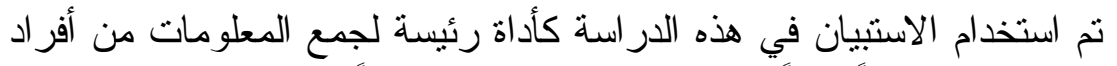

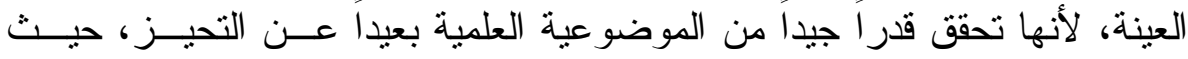

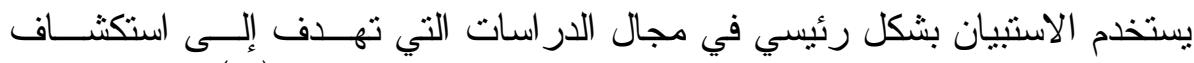

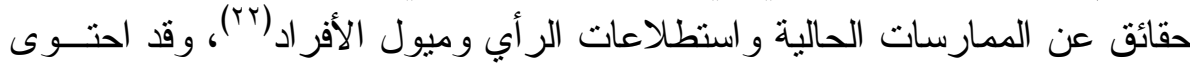

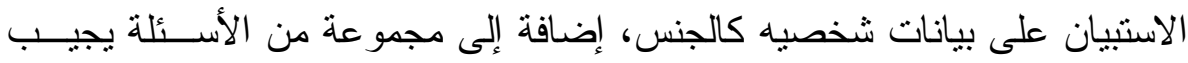
عليها المبحوث و التي تتضمن أسباب ودو افع استخدام المو اقع الإلكترونية.

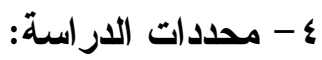

تتحدد نتائج هذه الدر اسة بما يلي:

1- اقتصار هذه الدر اسة على طلاب قسم الصحافة و الإعلام في جامعة البتر اء.

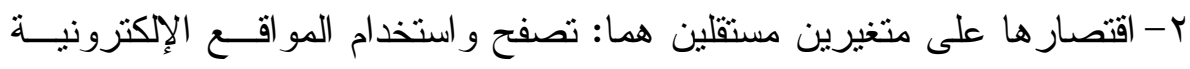

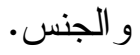

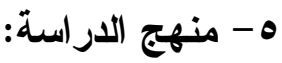

تصنف هذه الدر اسة ضمن البحوث الوصفية الني تستهلف تصوير وتحليـلـل

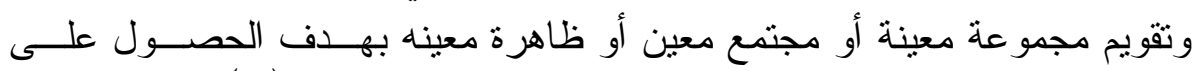

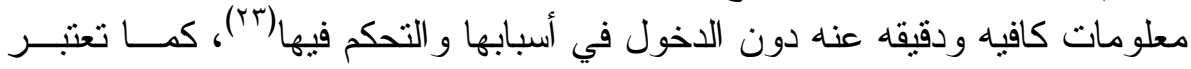

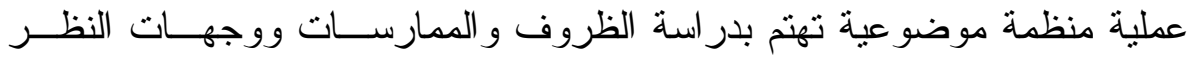

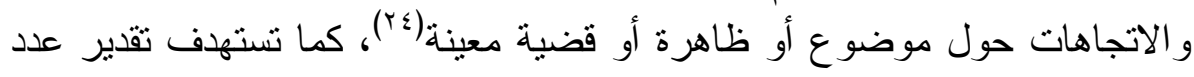

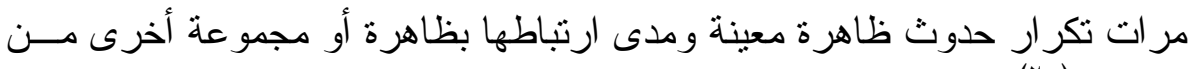

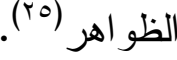

$$
\text { צ- أختبار الصدق و الثبات: }
$$

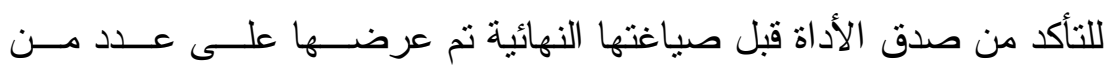

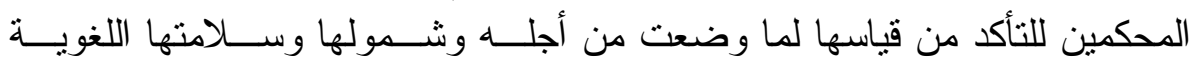

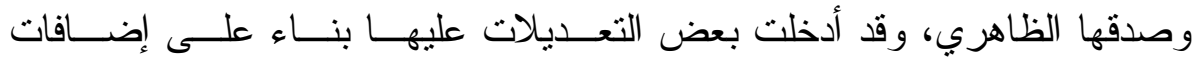

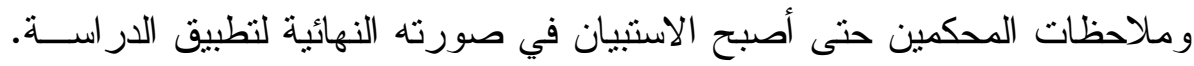


ومن ثم تم توزيع الاستيـــان على طلاب قنــم الصـــافة والإعــلام بحضـور

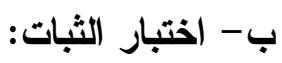

ويقصد بالثبات هو إمكانية نكرار التحليل و الحصول على نتائج ثابتة في كل

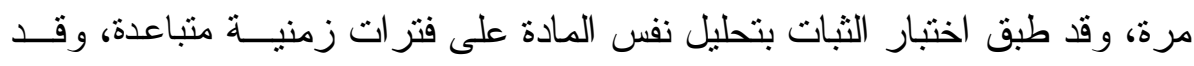

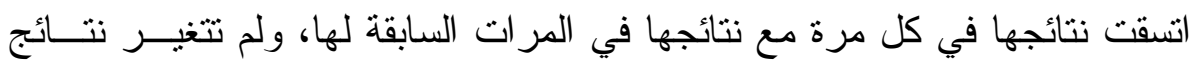

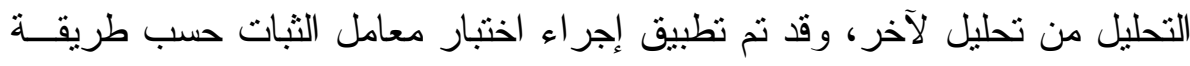
Holsti

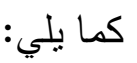

$$
\frac{11 \times r}{r+19}
$$

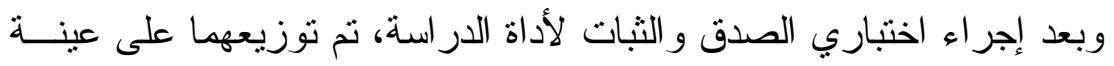

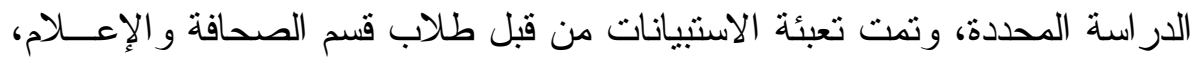

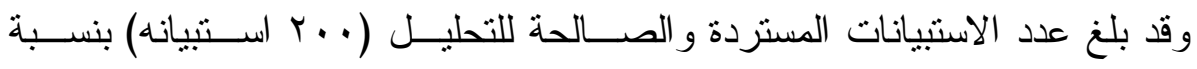
.\%1..

سادساً: عرض النتائج ومناقشتها:

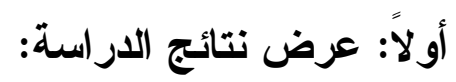

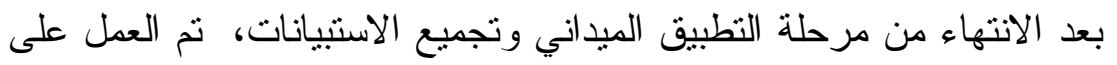

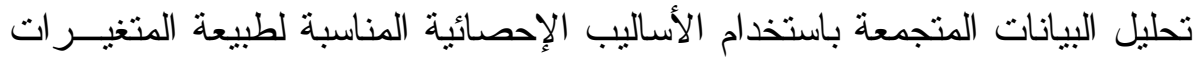

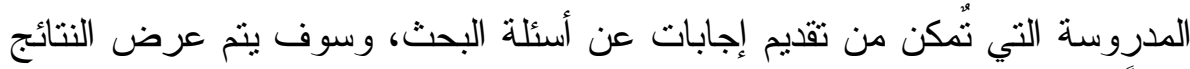

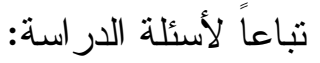


أ) عرض نتائج الدراسة حول استخدام طلاب قسم الصحافة والإعــلام

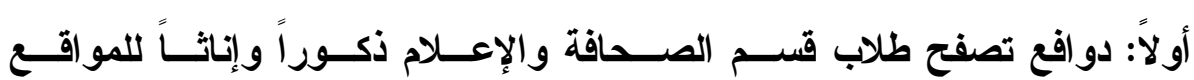

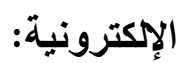

\begin{tabular}{|c|c|c|c|c|}
\hline \multicolumn{5}{|c|}{ الجدول رقم (r) } \\
\hline المئوية & المجموع & الإنكراث & الذكور & 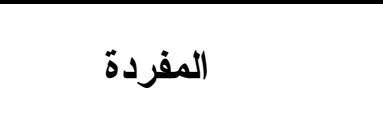 \\
\hline$\%$ ro & $\checkmark$. & rA & rr & التسلية وقضاء وقت فراغ \\
\hline$\% \curlyvee \wedge$ & 07 & rr & $r \varepsilon$ & التعليم و الدر اسة \\
\hline$\%$ \%r & $\leqslant 7$ & r & Tr & الدردشة ومر اسلة الآخرين \\
\hline$\% \backslash \leqslant$ & rA & $\mathrm{v}$ & r) & متابعة الأخبار و الإعلانات \\
\hline$\%$ & $r .$. & $1 \ldots$ & $1 \ldots$ & المجموع \\
\hline
\end{tabular}

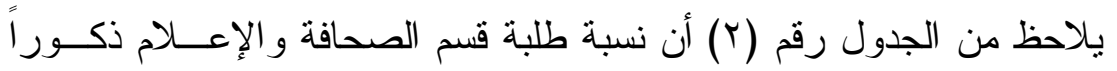

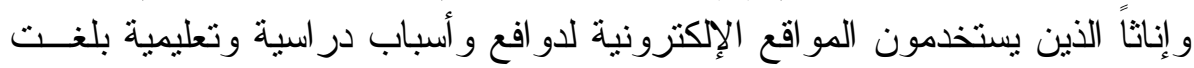

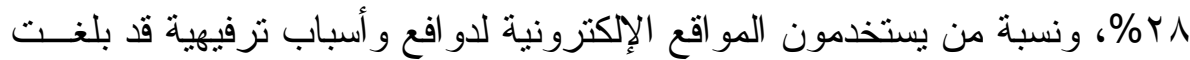

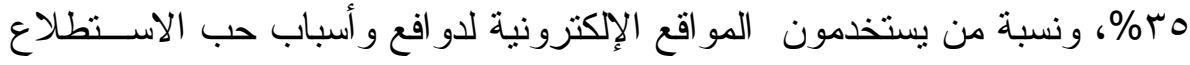

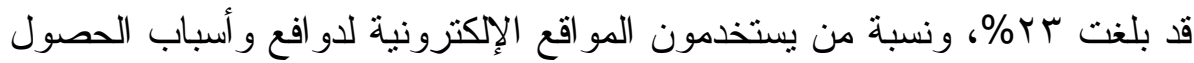

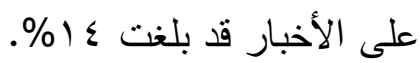

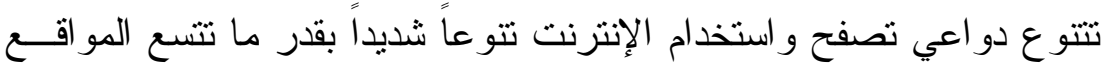

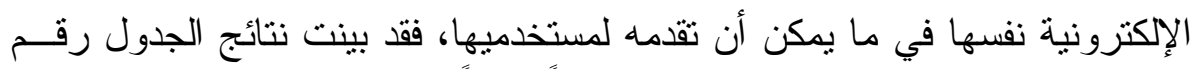

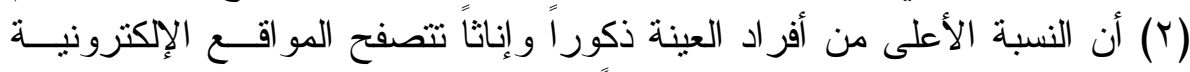

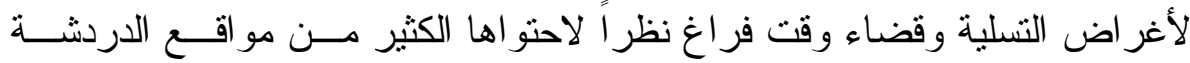

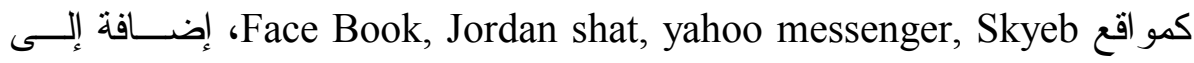

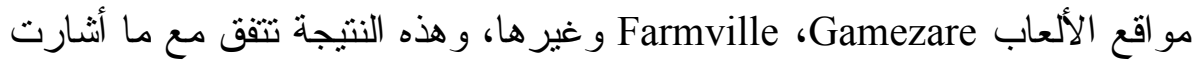

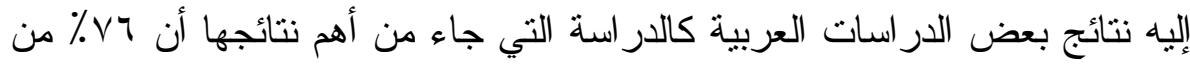

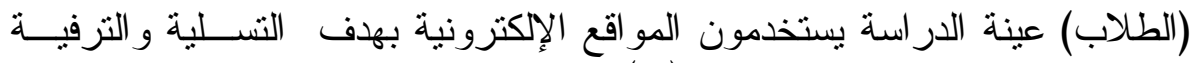

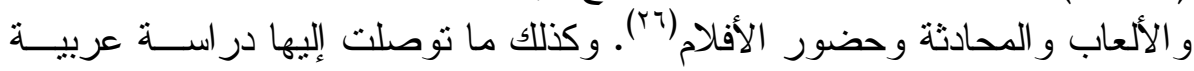

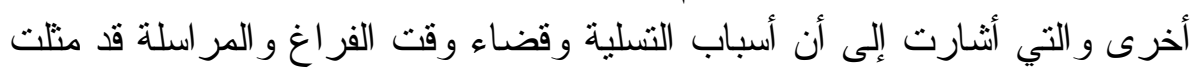


9\% من أسباب استخدام الثباب المصري للإنترنت، بينما مثل الاستخدام للتعلــيم

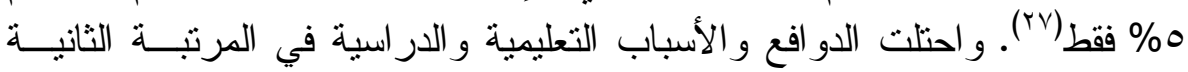

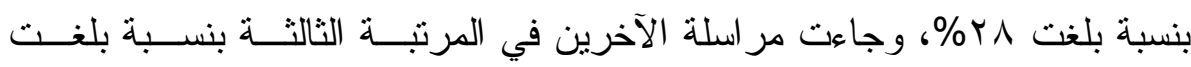

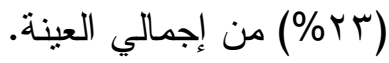

ثاتياً : المدة التي يقضيها الطلاب ذكوراً و إناثاً في تصفح المواقع الإكترونية: (r) (الجدول رقم

\begin{tabular}{|c|c|c|c|c|}
\hline المئوبة & المجموع & الإناث & الأكور & المفردة \\
\hline$\%$ \%r & $7 \varepsilon$ & YI & $\varepsilon r$ & ساعتان \\
\hline$\%$ & $\vee \wedge$ & $\varepsilon \wedge$ & r. & ثلاث ساعات \\
\hline$\% \backslash V$ & זr & 11 & 10 & أربع ساعات \\
\hline$\% \backslash r$ & ro & זו & Ir & خمس ساعات \\
\hline$\% 1 \ldots$ & r.. & $1 \ldots$ & $1 \ldots$ & المجمو ع \\
\hline
\end{tabular}

يلاحظ من الجدول رقم (ب) أن نسبة الطلاب الذين يقضون مدة ساعتان فـي

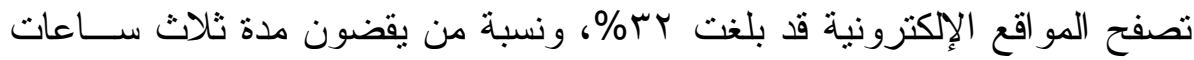

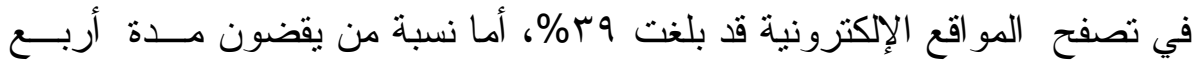

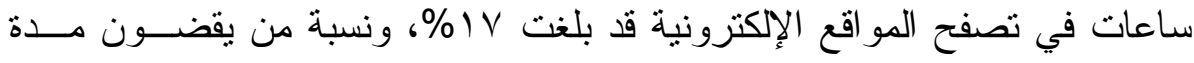

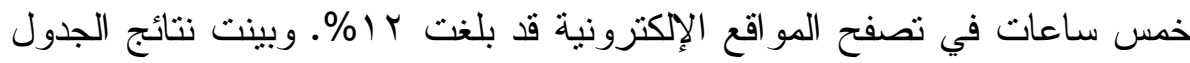

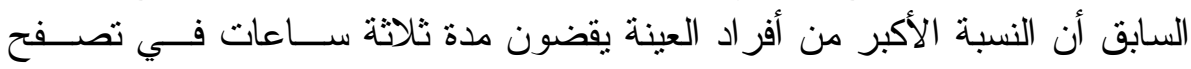
المو اقع الإلكترونية.

لقد بينت النتائج أن مدة ثثلاث ساعات يخصصها طلبة الصـــافة و الإعــلام

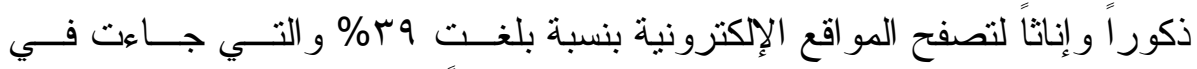

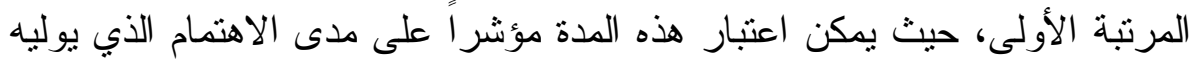

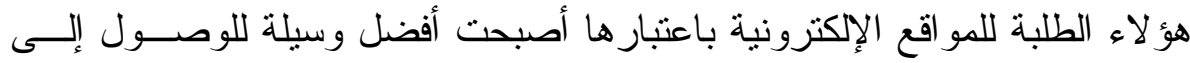

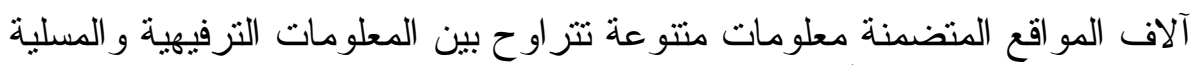

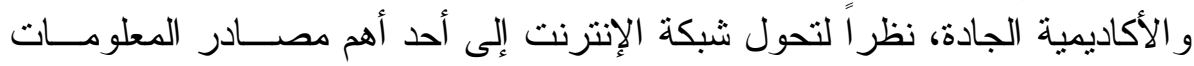

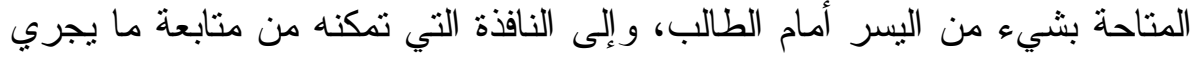

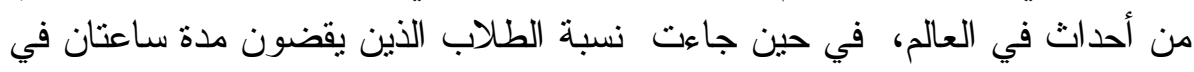


استخدام المو اقع الإلكترونية في المرتبة الثانية بنسبة rr\%. وتتعارض هذه النتيجة

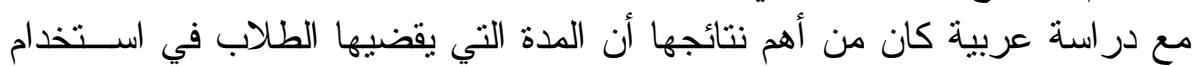

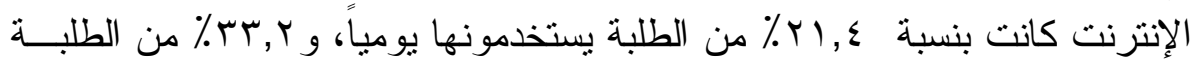

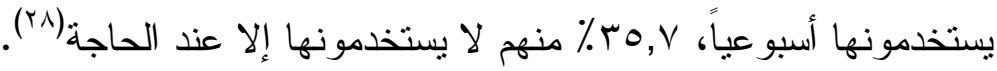

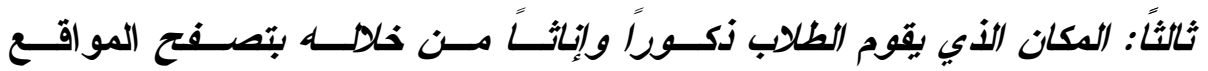

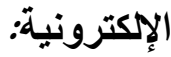

الجدول رقم (؛)

\begin{tabular}{|c|c|c|c|c|}
\hline المئوية & المجموع & الإخاث & تكرار & المفردة \\
\hline$\% 70$ & $1 \pi$ & 71 & Tr & المنزل \\
\hline$\%$ & ro & $1 \leqslant$ & 11 & مكتبة الجامعة \\
\hline$\% 1 r$ & ro & 10 & 1. & مختبر الكلية \\
\hline$\% 9$ & 19 & $r$ & 17 & مقاهي الإنترنت \\
\hline$\% 1 \ldots$ & r.. & $1 \ldots$ & $1 \ldots$ & المجموع \\
\hline
\end{tabular}

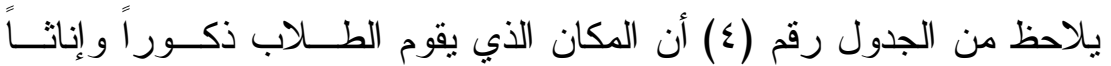

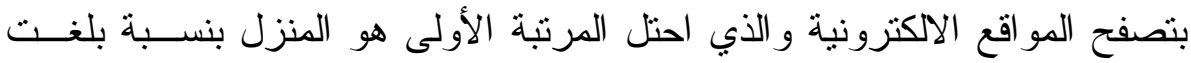

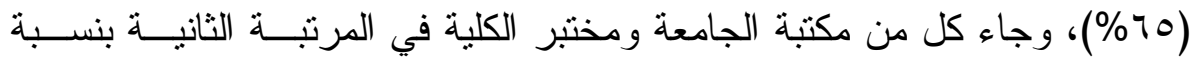

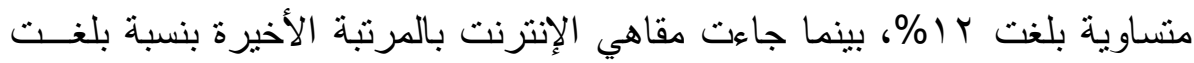

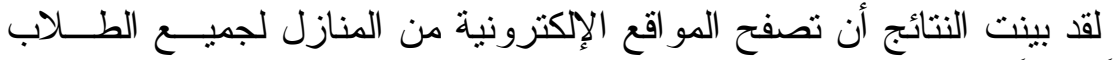

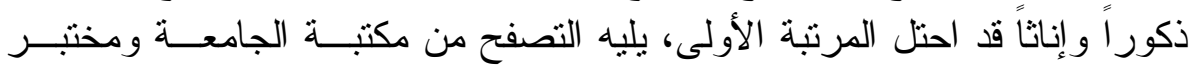

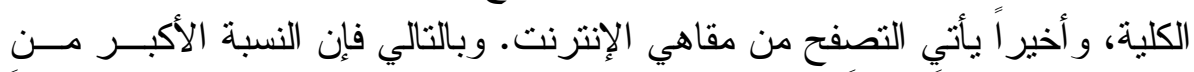

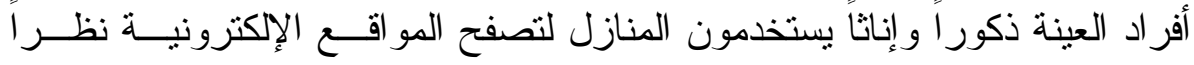
لسهولة الدخول إلى جميع المواقع، وعدم حجب أي موقع كما هو الحال في الجامعة الكئل

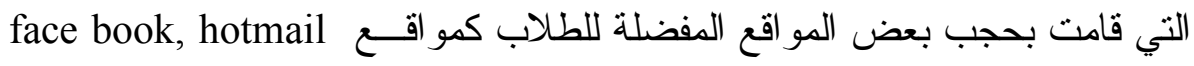
messenger, yahoo messenger

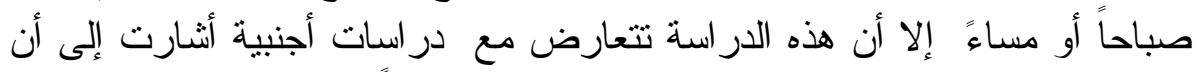

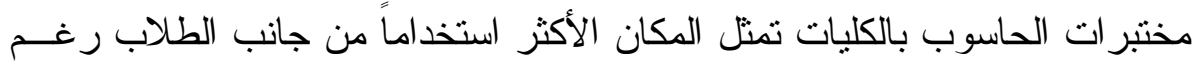




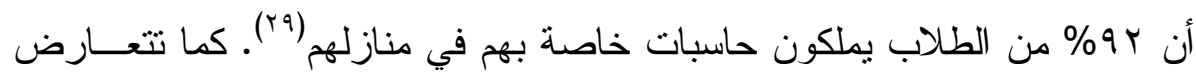

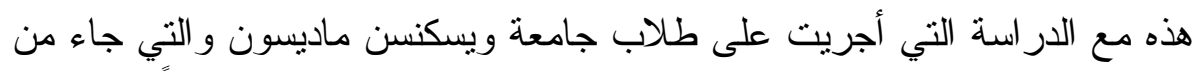

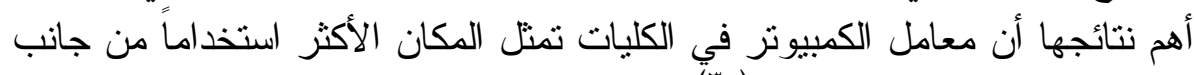

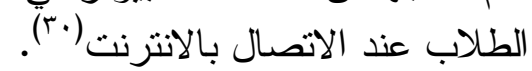
رابعًا: المواقع الإكترونية الأكثر تصفحًا ومتابعةً من قبل طلاب الصحافة والإعلام ذكوراً وإناثًا:

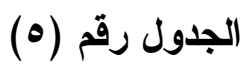

\begin{tabular}{|c|c|c|c|c|}
\hline المئوية & المجموع & تكرار & الذكرر & الموقع \\
\hline$\% 70$ & M. & 79 & 71 & Face Book \\
\hline$\% r$ & V & r & $\varepsilon$ & Utube \\
\hline$\%$ r. & 7. & rA & rT & Google \\
\hline$\% r$ & r & - & $r$ & Yahoo \\
\hline$\% 1 \ldots$ & r.. & $1 \ldots$ & $1 \ldots$ & جموع \\
\hline
\end{tabular}

يلاحظ من الجدول رقم (0) أن الموقع الالكتروني Face Book أكثر المواقع

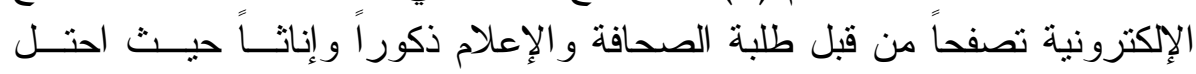

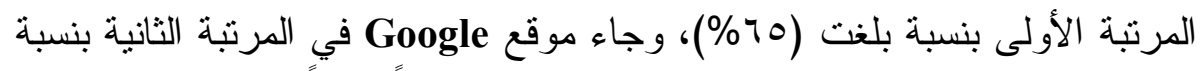

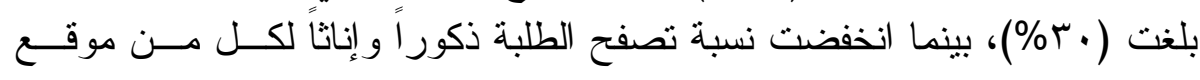

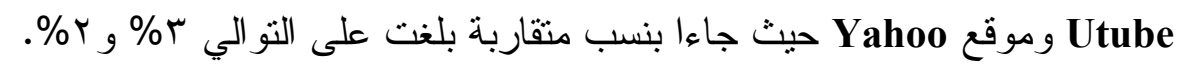
بينت النتائج أن موقع Face Book أكثر المواقع الإلكترونية تصــفحاً بــين

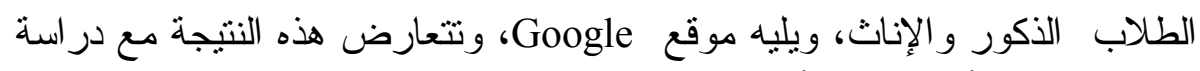

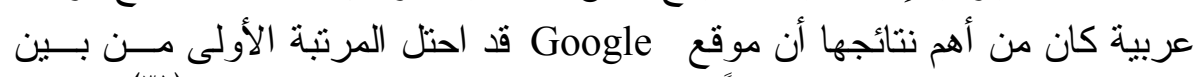

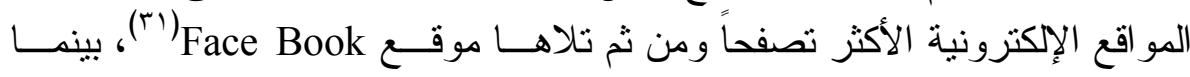

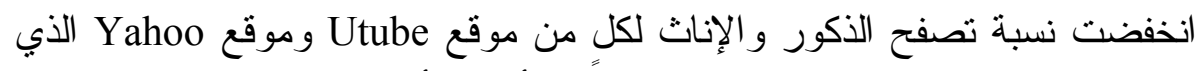

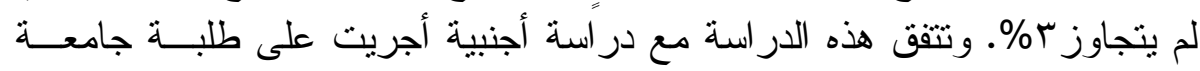

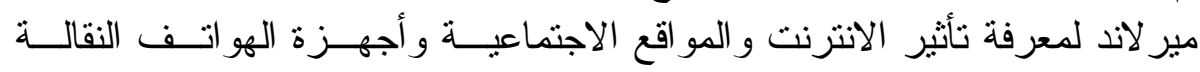

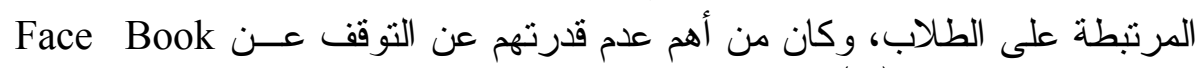

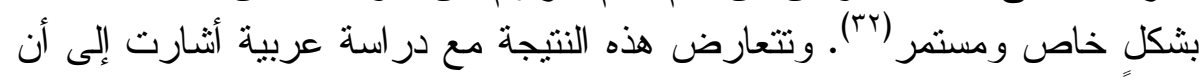


موقع YOU TUBE هو المفضل والأكثر تصفحاً ومروراً بالنسبة لشريحة كبيــرة

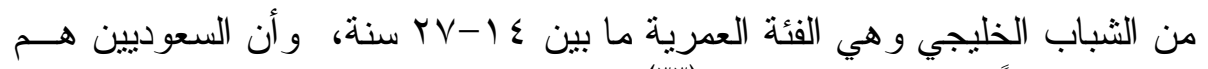
الأكثر اجتياحاً لهذا الموقع المشهور (rr). خامساً : اعتبار الطلاب نكورًا وإناثًا المواقع الإلكترونية مصدرًا للمعلومات:

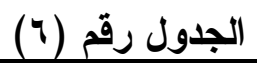

\begin{tabular}{|c|c|c|c|c|}
\hline النسبة المئوية & المجموع & تكرار الإناث & تكرار الأكور & المفردة \\
\hline$\% \vee 1$ & $1 \leqslant r$ & 71 & $V \varepsilon$ & نعم \\
\hline$\% 11$ & YI & Ir & 9 & $\bar{y}$ \\
\hline$\% \backslash 1$ & rv & $r$. & IV & أحياناً \\
\hline$\% 1 \ldots$ & r.. & $1 \ldots$ & $1 \ldots$ & المجموع \\
\hline
\end{tabular}

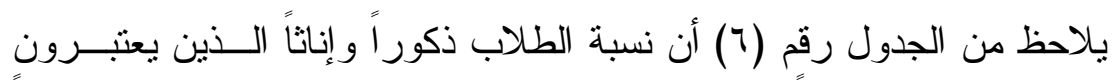

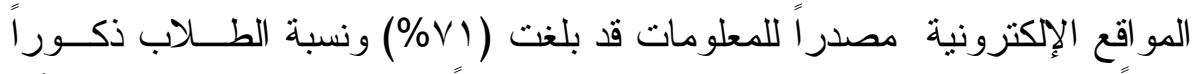

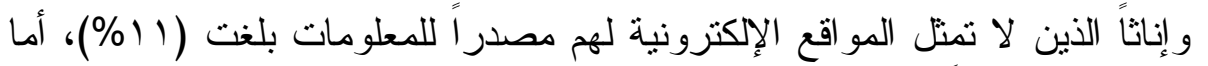

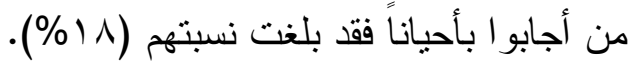

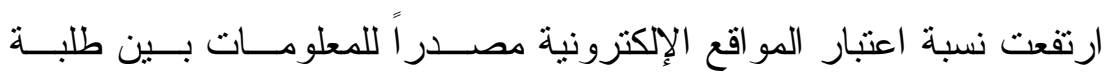

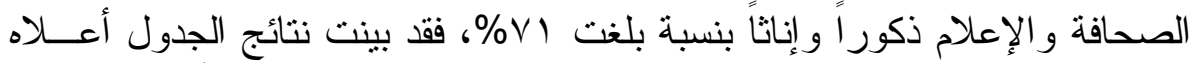

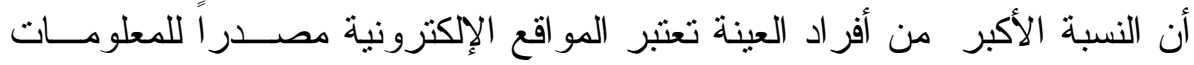
بسبب سهولة الحصول على معلومات في جميع التخصصات و المجالات، كالإعلام

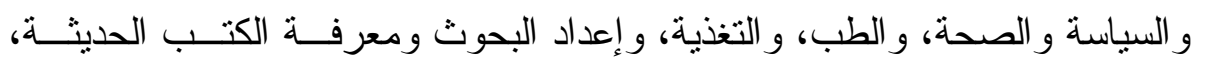

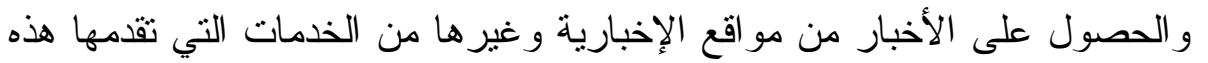

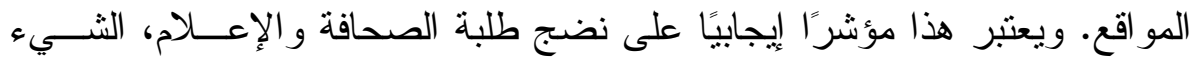

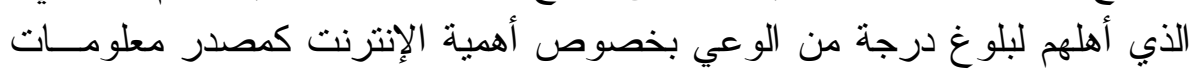

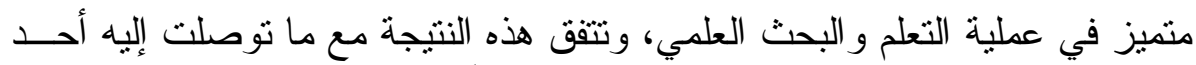

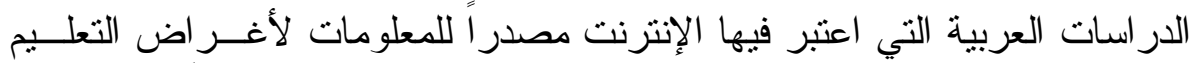

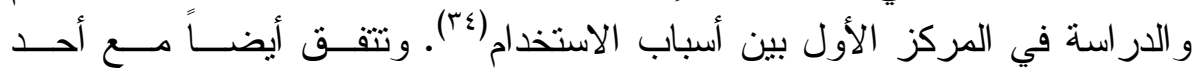

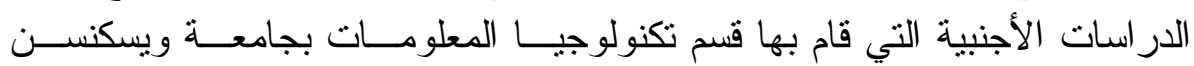
ماديسون التي كثفت أن الطلاب يعتبرون شبكة الإنترنت مصدر أ للمعلومات وات وأنها

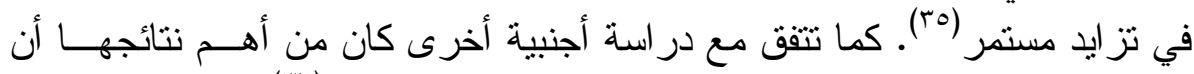

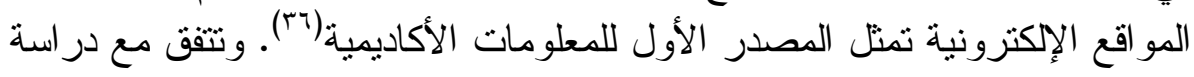


أجنبية أخرى جاء أظهرت نتائجها موقفاً إيجابياً للطلبة تجاه الإنترنـــ، إذ أفــادو ا

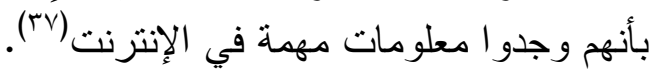

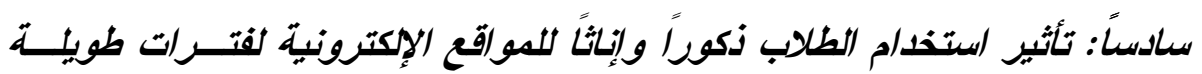
على تحصيلهم الدراسي:

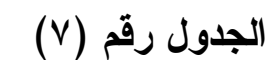

\begin{tabular}{|c|c|c|c|c|}
\hline النسبة المئوية & المجموع & تكرار الإناث & تكرار الذكور & المفردة \\
\hline$\%$ ro & 01 & $r \varepsilon$ & TV & نعم \\
\hline$\%$ \% & VA & rq & rq & $y$ \\
\hline$\% r_{4}$ & VI & rv & $\Gamma \varepsilon$ & أحياناً \\
\hline$\% 1 \ldots$ & r.. & $1 \ldots$ & $1 \ldots$ & المجموع \\
\hline
\end{tabular}

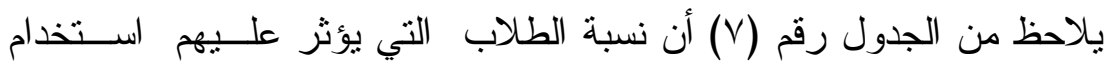

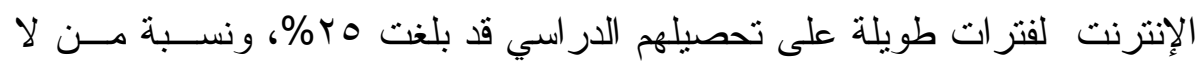

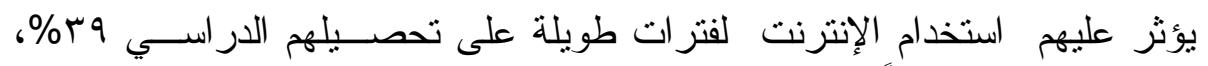

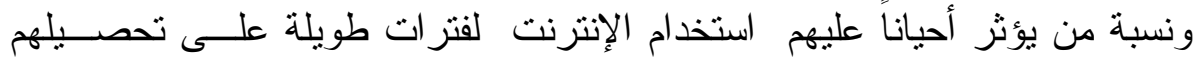

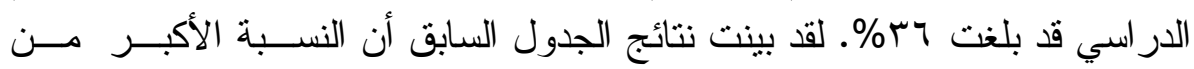

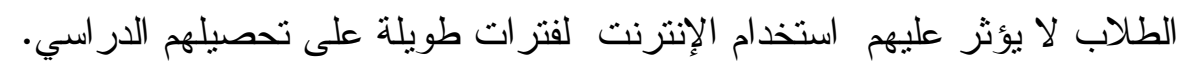

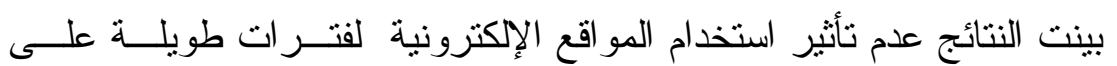

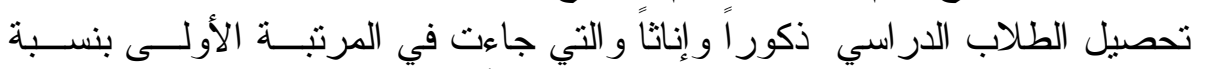

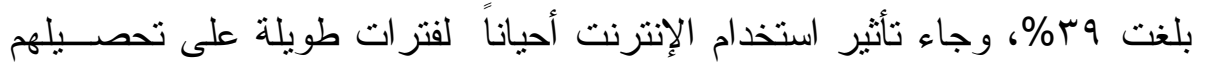

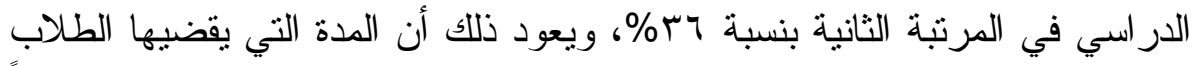

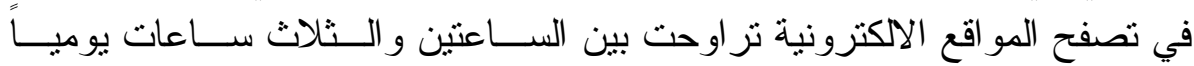

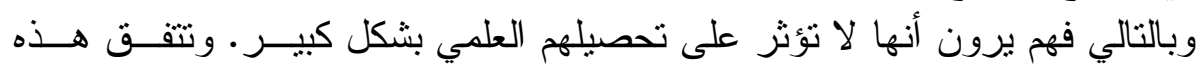
النتيجة مع ما توصلت إليه أحد الدراسات الأجنيية حول استخدام الطلاب للإنترنت

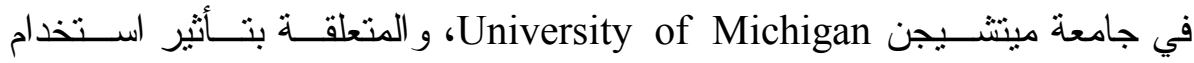

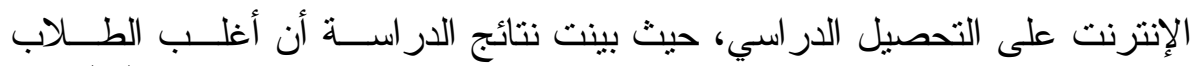

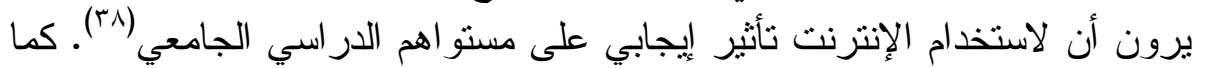

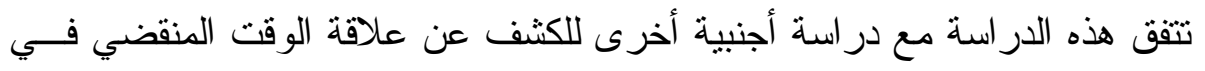
استخدام الإنترنت بالتحصيل الدراسي و الني كان من أهم نتائجها عدم وجود علائة الكاقة 
دالة بين المتغيرين. وهو ما يثير إلى أن الوقت المنقضي في اســـتخدام الإنترنـــت

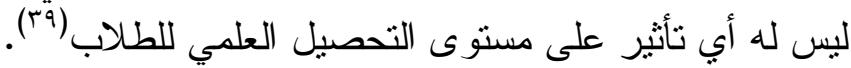

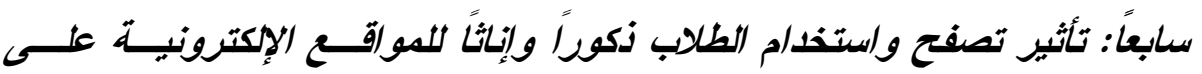

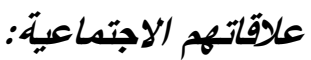

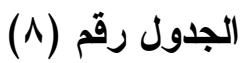

\begin{tabular}{|c|c|c|c|c|}
\hline النسبة المئوية & المجموع & تكرار الإخاث & تكرار الذكور & المفردة \\
\hline$\%$ \% & 91 & $r q$ & or & نعم \\
\hline$\%$ \% & or & ru & rq & $y$ \\
\hline$\%$ \%ч & or & חז & 19 & أحياناً \\
\hline$\% 1 \ldots$ & r... & $1 \ldots$ & $1 \ldots$ & المجموع \\
\hline
\end{tabular}

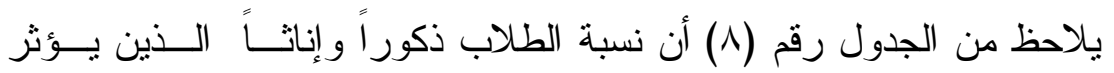

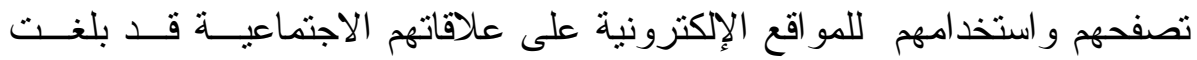

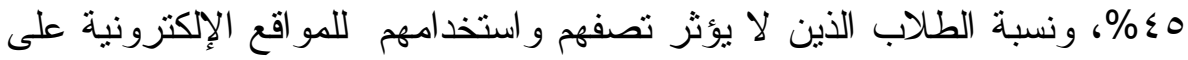

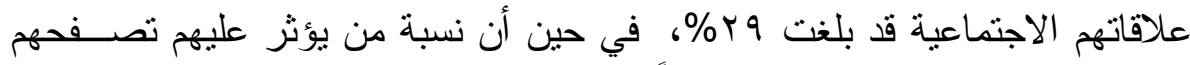

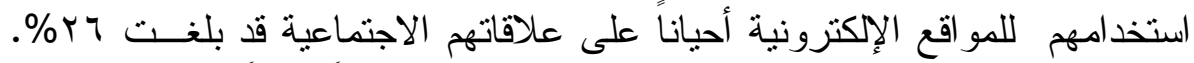

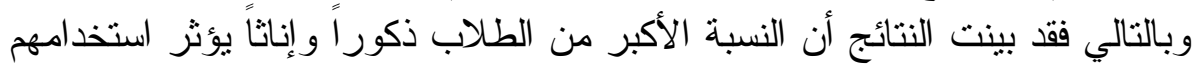

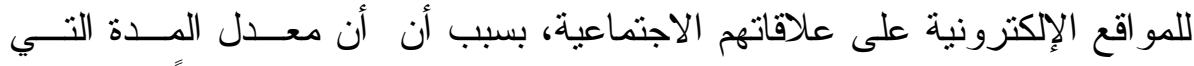

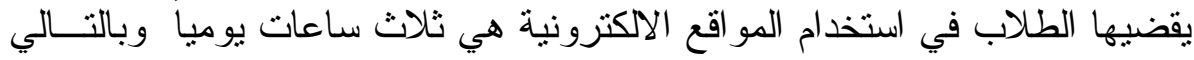

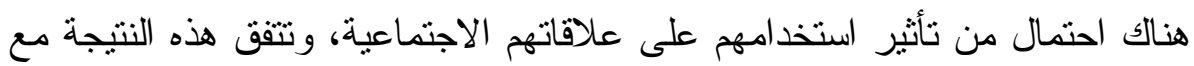

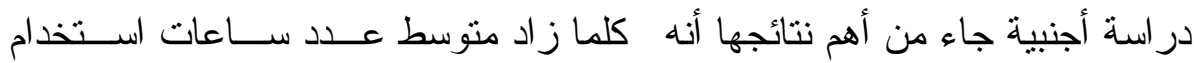

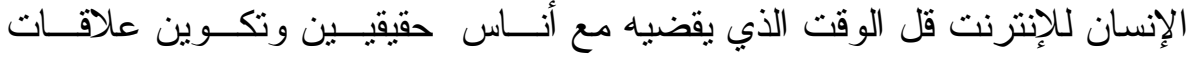

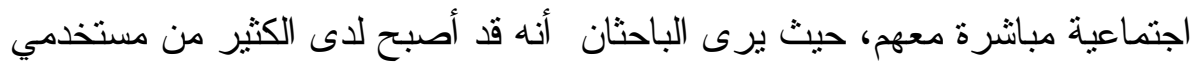

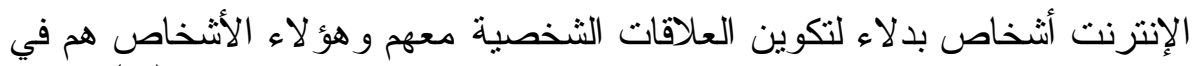

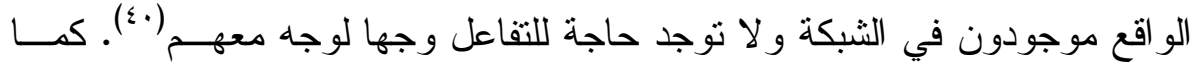

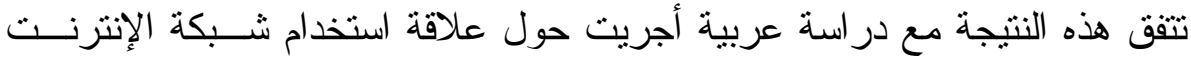

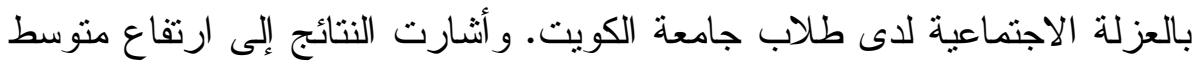

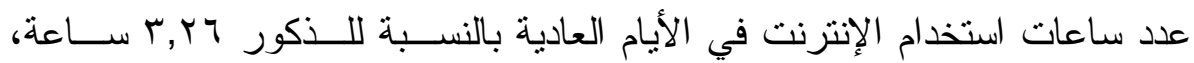

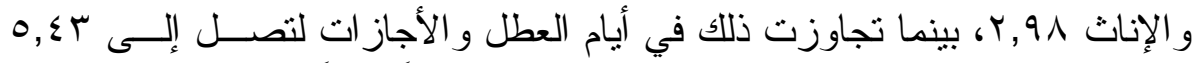

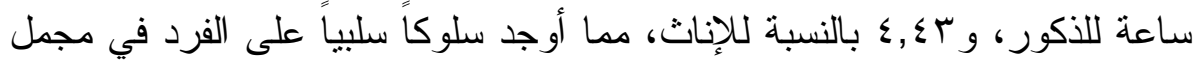


علاقاته الاجتماعية (1). وتتفق أيضاً مع دراسة عربية أخرى التي حاولت التركيـز

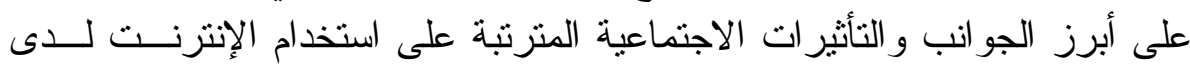

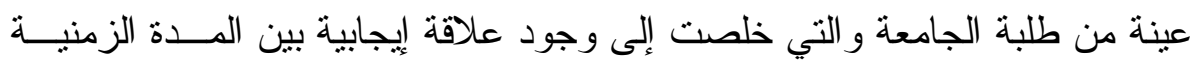

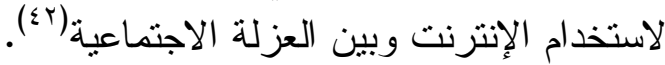

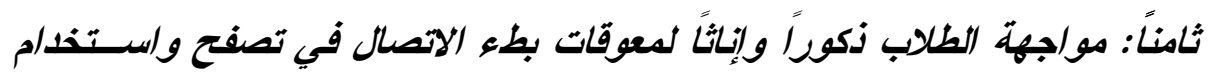
المواقع الإكترونية في الجامعة:

(9) الجدول رقم (9)

\begin{tabular}{|c|c|c|c|c|}
\hline النسبة المئوية & المجموع & تكر ار الإناث & تكرار الأكور & المفردة \\
\hline$\% \leq V$ & 90 & or & $\varepsilon r$ & نعم \\
\hline \%rr & $\varepsilon \varepsilon$ & 11 & $r 7$ & $y$ \\
\hline$\%$ & 71 & rq & r & أحياناً \\
\hline$\% 1 \ldots$ & r.. & $1 \ldots$ & $1 \ldots$ & المجمو ع \\
\hline
\end{tabular}

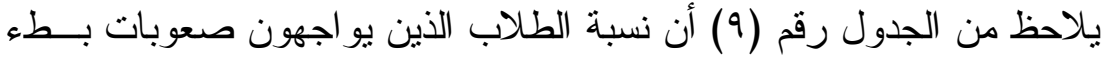

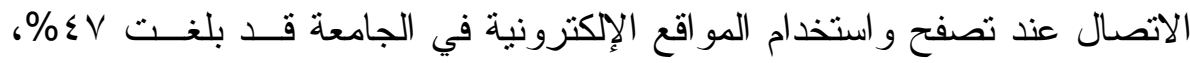

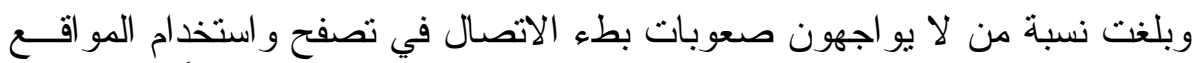

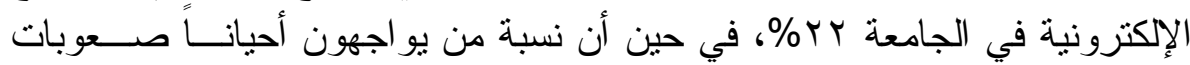

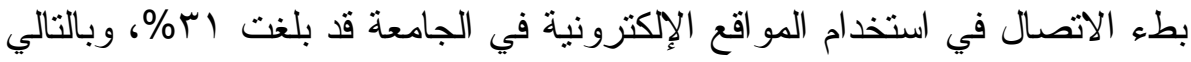

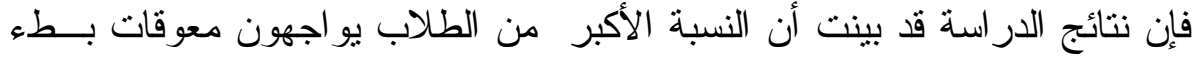

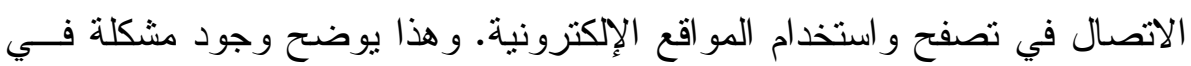

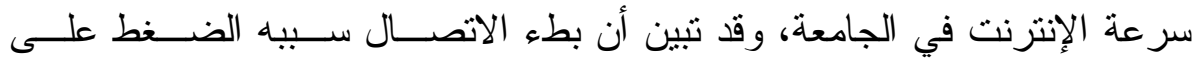

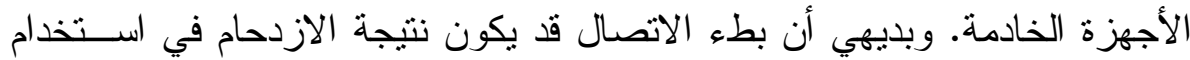

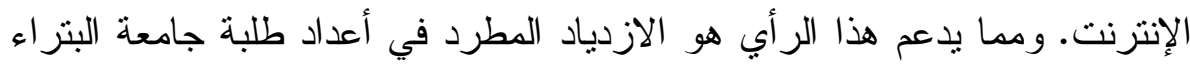

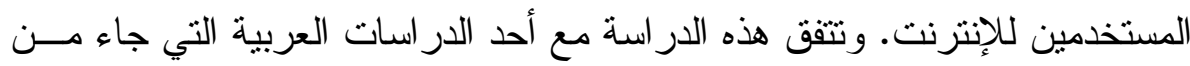

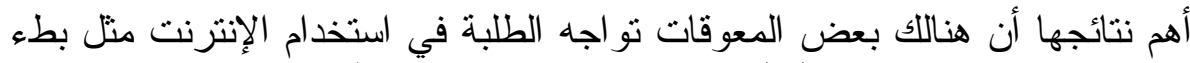

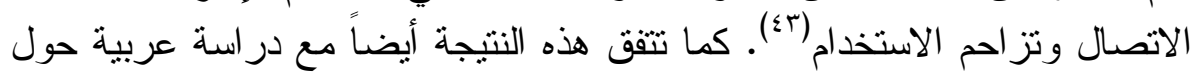

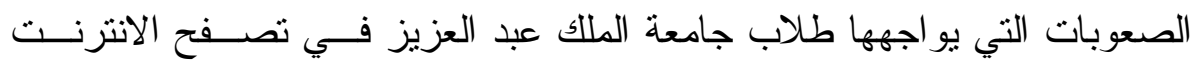

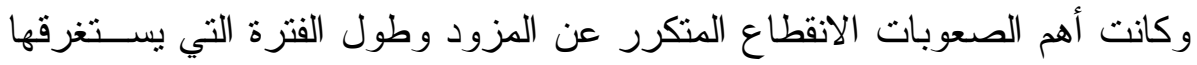

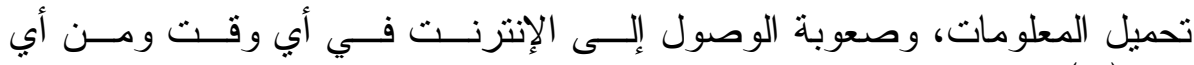
مكان («) 
تاسعاً: مواجهة الطلاب ذكوراً وإناثًا صعويات اللغة الإجليزية عند استغدم بعض

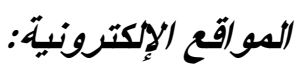

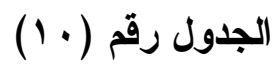

\begin{tabular}{|c|c|c|c|c|}
\hline النسبة المئوية & المجموع & تكرار الإناث & تكرار الأكور & المفردة \\
\hline$\%$ \%. & 7. & ו & rq & نعم \\
\hline$\%$ \% & $0 \wedge$ & צץ & rt & $y$ \\
\hline$\% \leqslant 1$ & 11 & r & $\leqslant 9$ & أحياناً \\
\hline$\% 1 \ldots$ & r... & $1 \ldots$ & $1 \ldots$ & المجمو ع \\
\hline
\end{tabular}

يلاحظ من الجدول رقم (· (1) أن نسبة الطلاب الذين يو اجهون صـع بعوبات

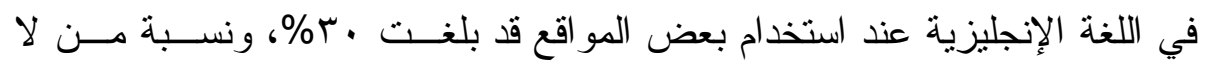

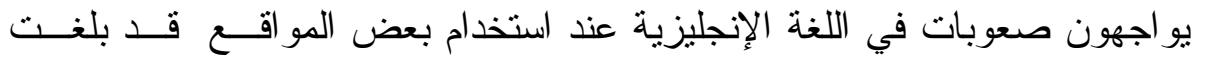

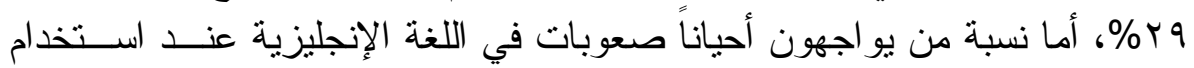

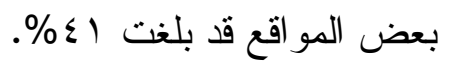

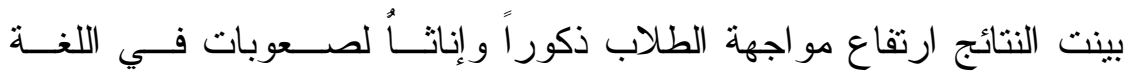

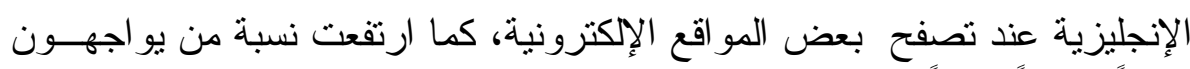

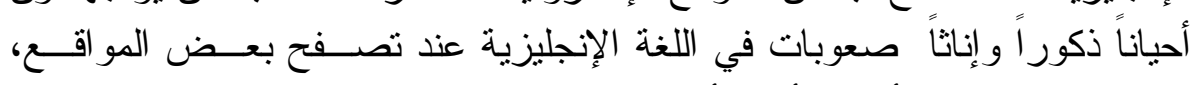

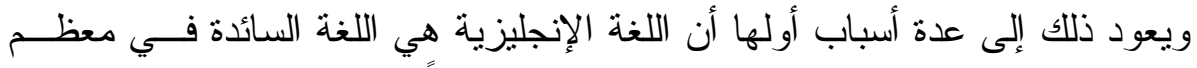

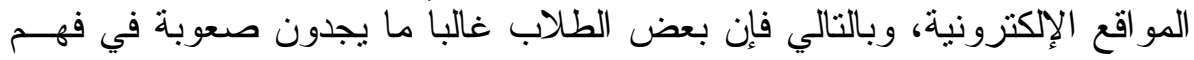

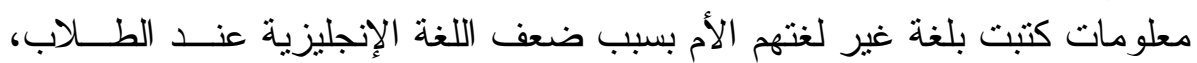

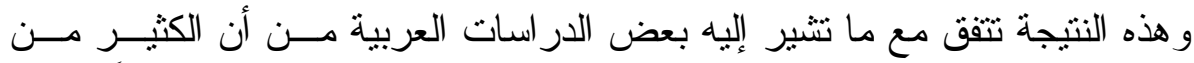

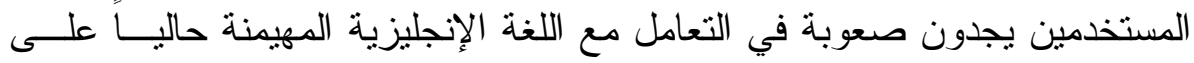

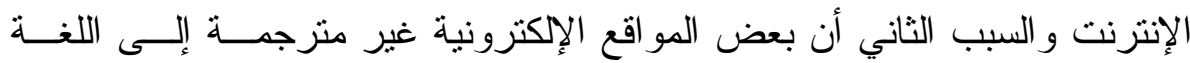

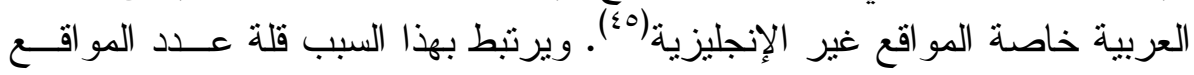

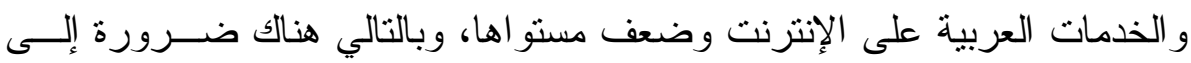

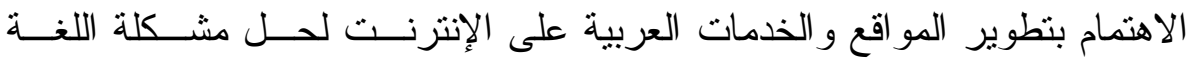

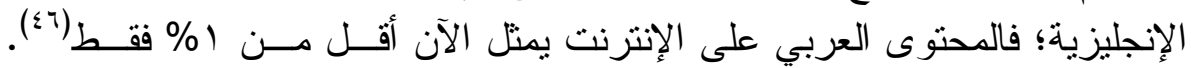

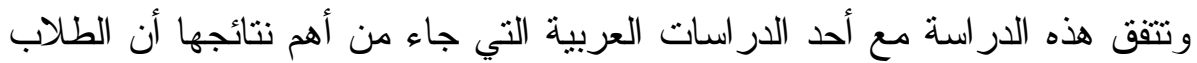

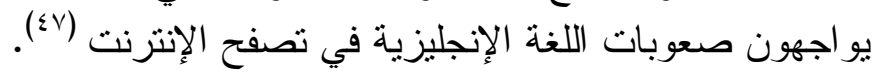


عاثراً: مواجهة الطلاب ذكورًا وإناثًا مشكلة حجب بعض المواقع الإكترونية فـ

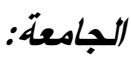

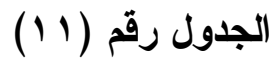

\begin{tabular}{|c|c|c|c|c|}
\hline النسبة المئوية & المجموع & تكرار الإناث & تكرار الأكور & المفردة \\
\hline$\% \circ 1$ & $11 \mathrm{~V}$ & $0 \leqslant$ & Tr & نعم \\
\hline$\% 19$ & rᄉ & 11 & r. & ע \\
\hline$\%$ \%r & $\leqslant 0$ & rı & IV & أحياناً \\
\hline$\% 1 \ldots$ & r... & $1 \ldots$ & $1 \ldots$ & المجموع \\
\hline
\end{tabular}

يلاحظ من الجدول رقم (1) أن نسبة الطلاب ذكوراً و إناثاً الذين يو اجهون

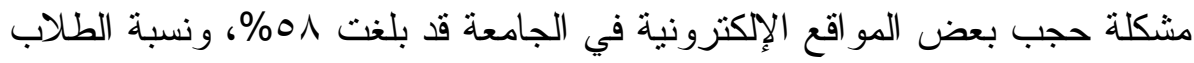

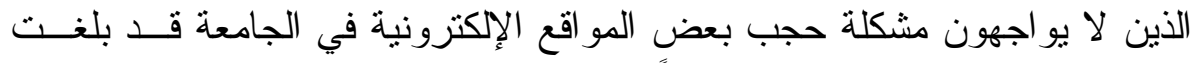

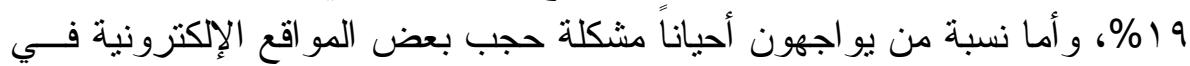

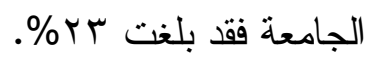

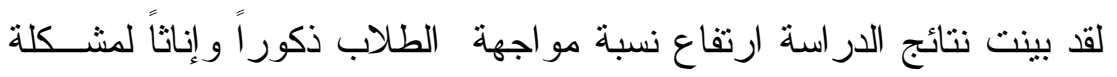

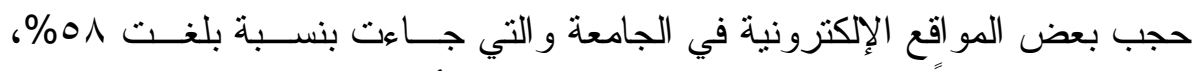

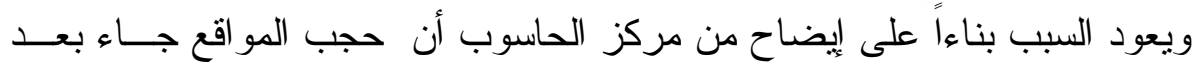

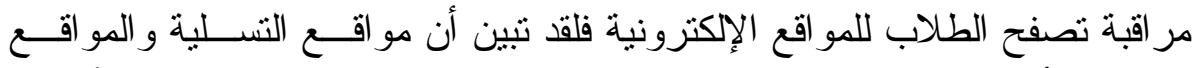

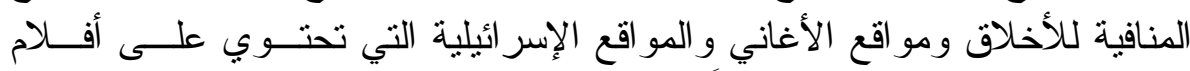

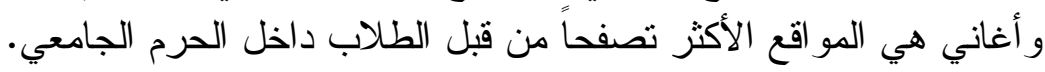

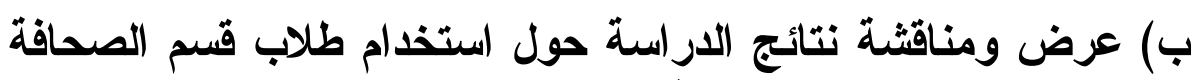
والإعلام للمواقع الإكترونية حسب متنغير الجنس:

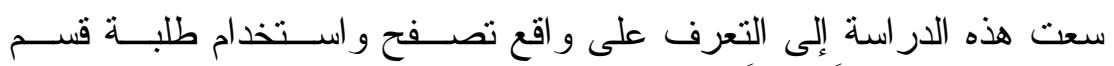

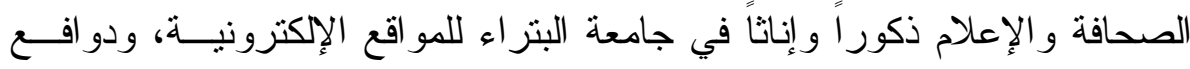

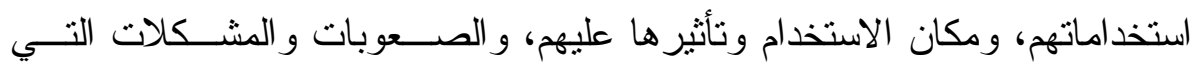

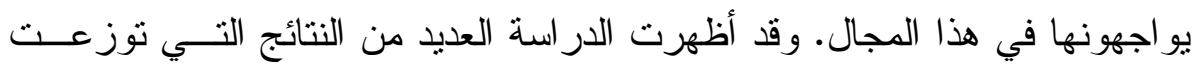

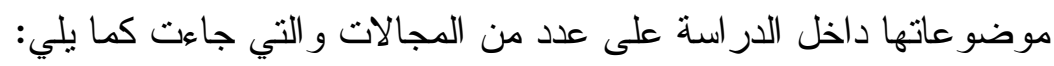


أولاً: مقارنة دو افع تصفح طلاب قسم الصحافة والإعلام ذكوراً و إناثـاً للمواقـــع

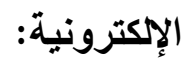

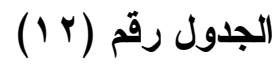

\begin{tabular}{|c|c|c|c|c|}
\hline المئوية & الإناث & المئوية & الذكرور & المفردة \\
\hline$\%$ \%r & rr & $\% r \leq$ & $r \varepsilon$ & تعليمي \\
\hline$\%$ \% & rᄉ & $\%$ \%r & rr & تزفيهي \\
\hline$\%$ \% & $r$ & $\%$ \%r & $r \mu$ & الدردشة ومر اسلة الآخرين \\
\hline$\% \vee$ & v & $\%$ r & rI & مصدر للأخبار \\
\hline$\% 1 \ldots$ & $1 \ldots$ & $\% 1 \ldots$ & $1 \ldots$ & المجموع \\
\hline
\end{tabular}

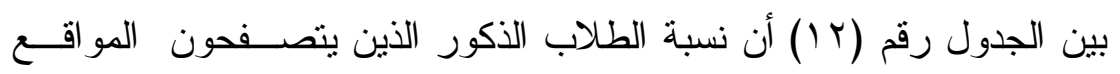

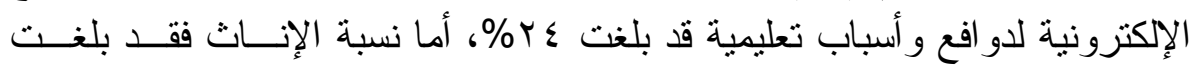

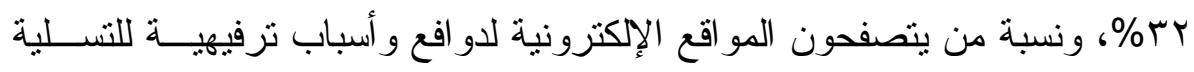

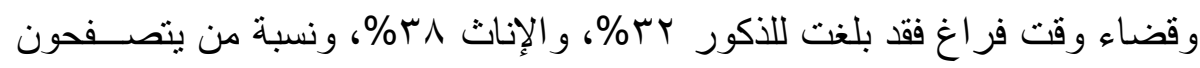

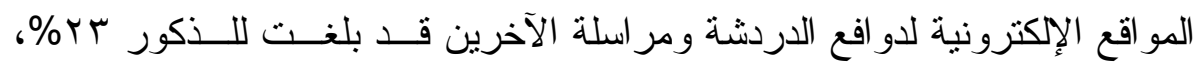

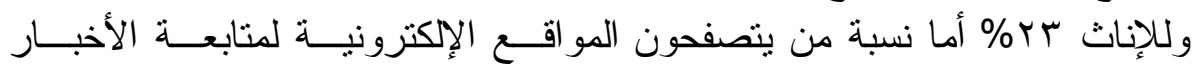

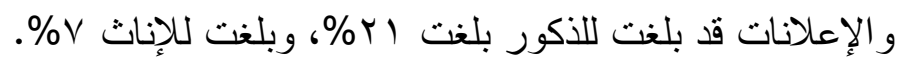

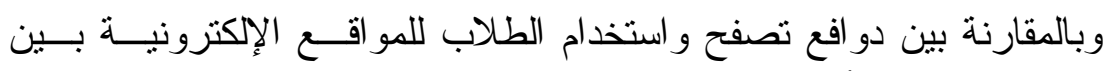

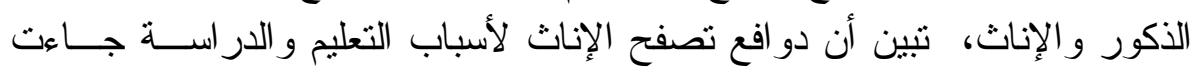

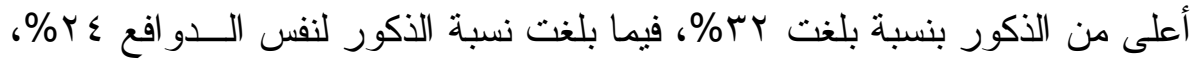

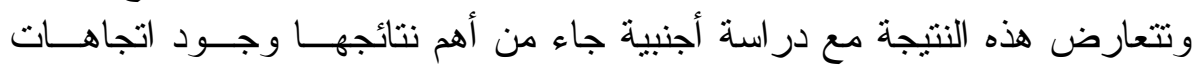

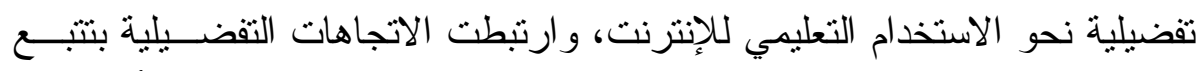

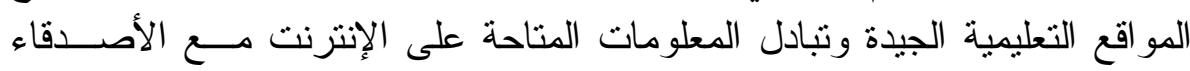

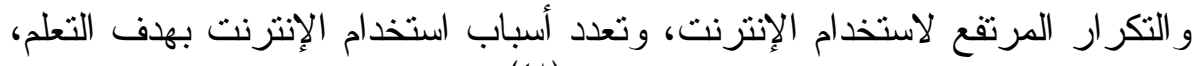

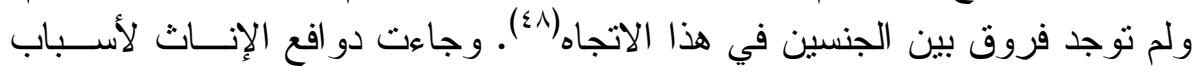

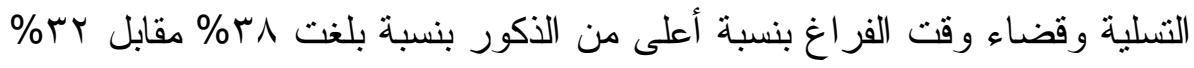

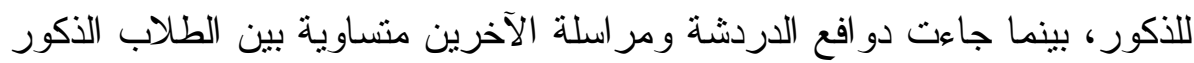

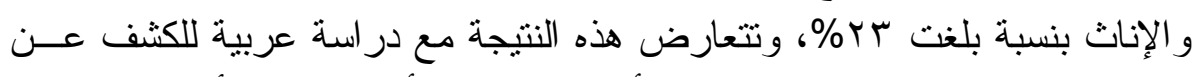

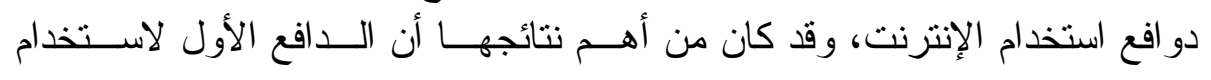


الإنترنت لدى الطلبة طلب المعرفة، يلي ذلك المتعة و الترويح، ثم تكوين علاقـات

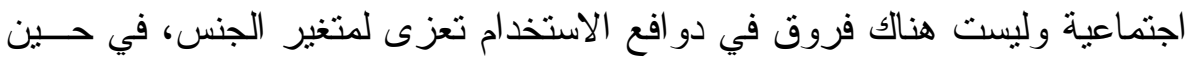

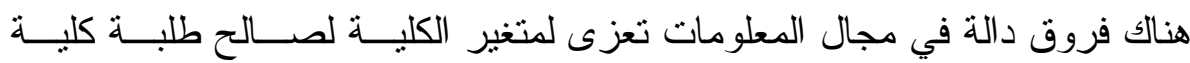

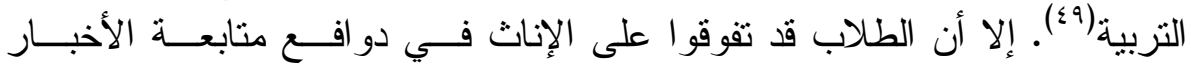

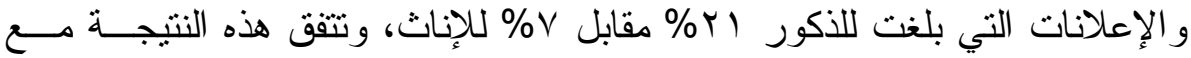

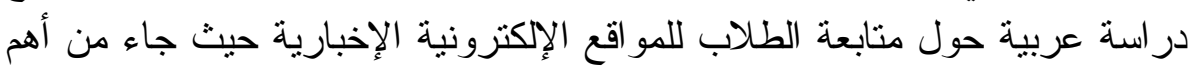

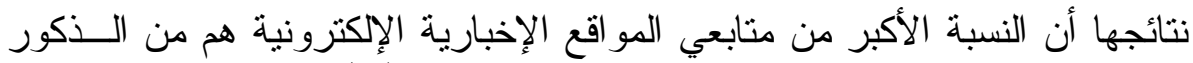

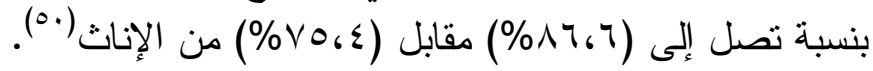

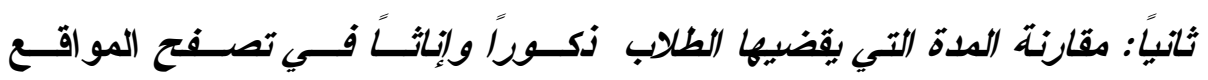
الإكترونية:

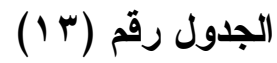

\begin{tabular}{|c|c|c|c|c|}
\hline النسبة المئوية & تكرار الإناث & النسبة المئويـة & تكرار الأكور & المفردة \\
\hline$\%$ Y & YI & $\% \leq r$ & $\varepsilon r$ & ساعتان \\
\hline$\% \leqslant 1$ & $\varepsilon \wedge$ & $\%$ \%. & r. & ثلاث ساعات \\
\hline$\% \backslash \wedge$ & 11 & $\% 10$ & 10 & أربع ساعات \\
\hline \%) & M & $\% \backslash$ & Ir & خمس ساعات \\
\hline$\% 1 .$. & $1 \ldots$ & $\% 1 \ldots$ & $1 \ldots$ & المجموع \\
\hline
\end{tabular}

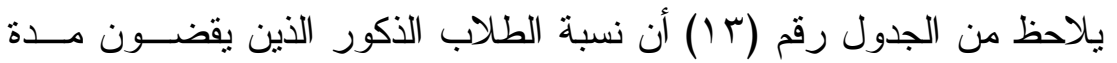

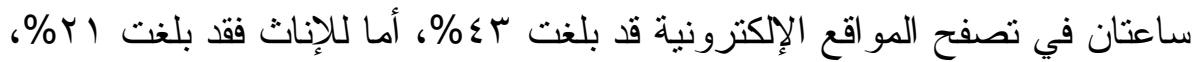

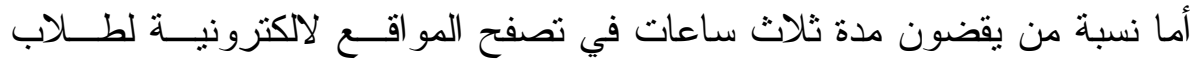

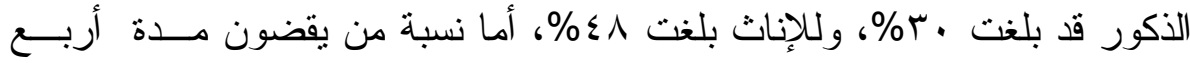

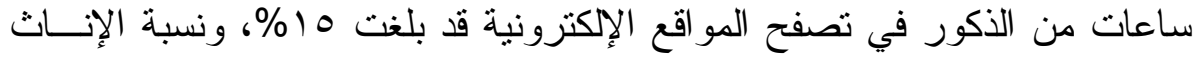

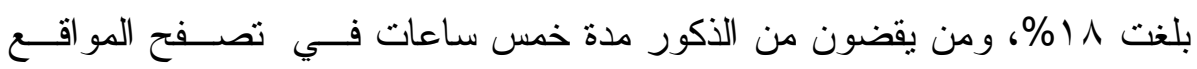

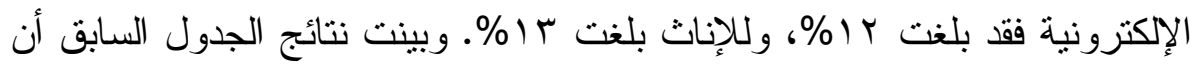

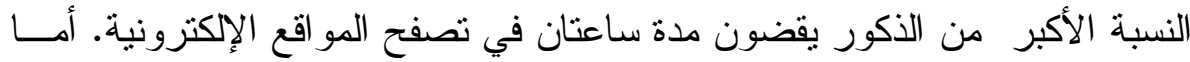

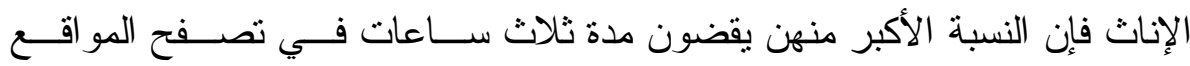
الإككترونية. 


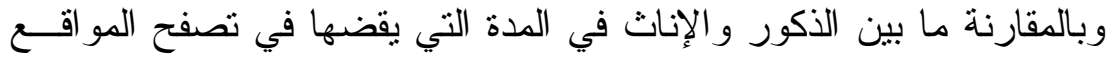

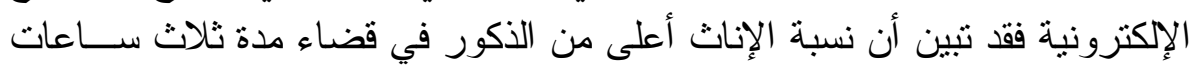

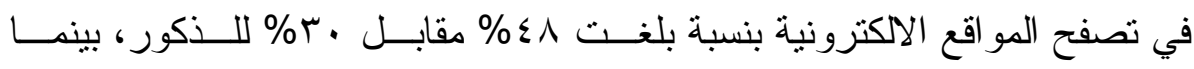

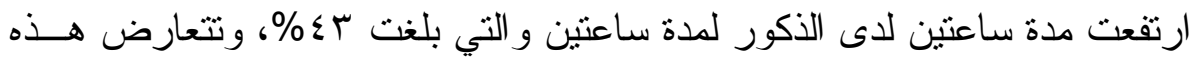

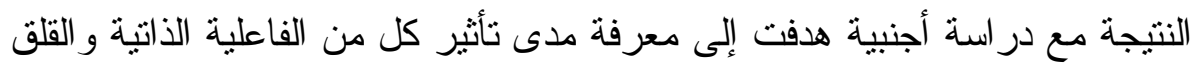

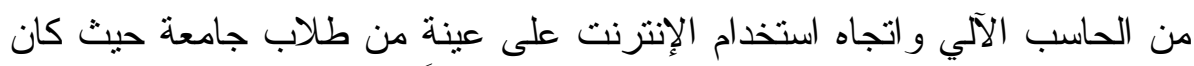

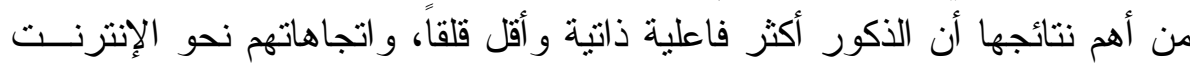

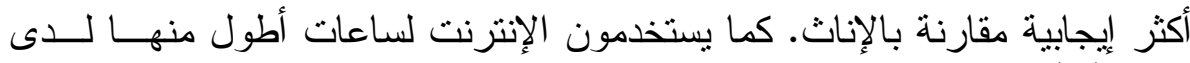

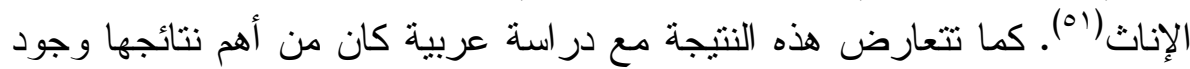

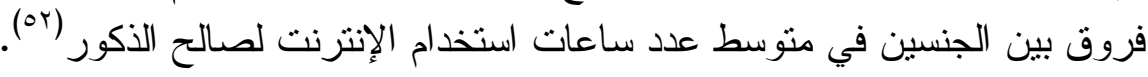

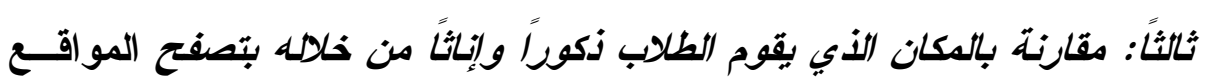

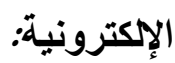

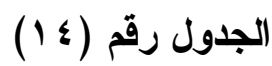

\begin{tabular}{|c|c|c|c|c|}
\hline المئوية & الإداث & المئوية & الذكور & المفردة \\
\hline$\% \uparrow \wedge$ & 71 & תז\% & זיד & المنزل \\
\hline$\% 10$ & 10 & $\% 17$ & 17 & مقاهي الإنترنت \\
\hline$\% \backslash \varepsilon$ & $1 \varepsilon$ & $\% 11$ & 11 & مكتبة الجامعة \\
\hline$\% r$ & $r$ & $\% 1$. & 1. & مختبر الكلبة \\
\hline$\% 1 \ldots$ & $1 \ldots$ & $\% 1 \ldots$ & $1 \ldots$ & المجموع \\
\hline
\end{tabular}

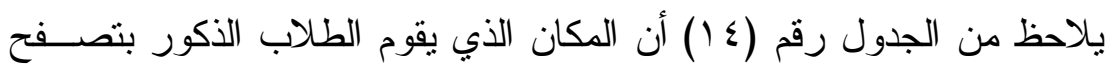

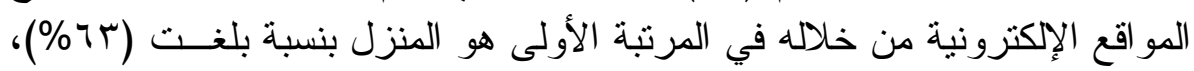

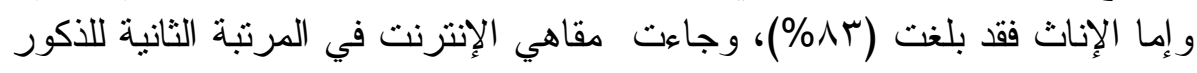

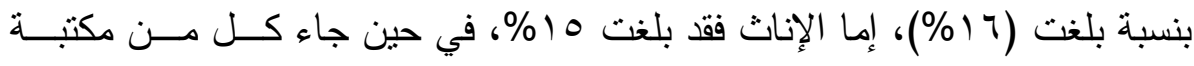

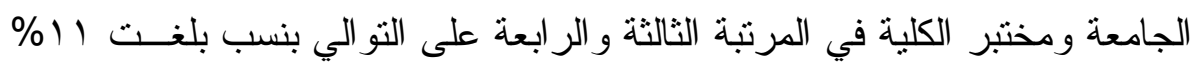

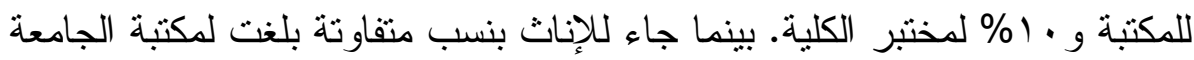

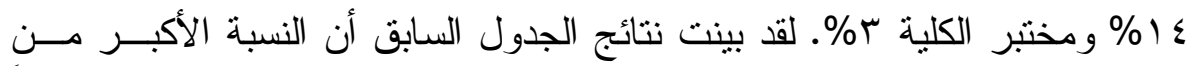

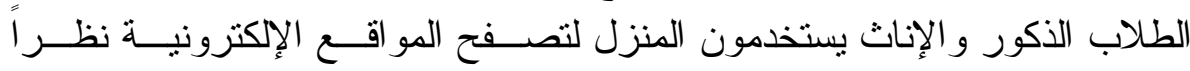

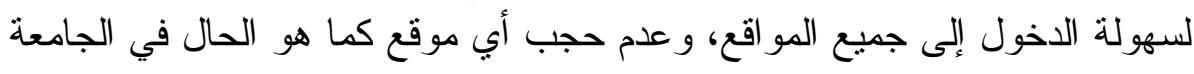




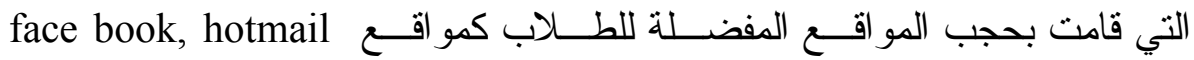
messenger, yahoo messenger صباحاً أو مساءاً.

وبالمقارنة بين طلاب الصحافة والإعلام ذكوراً و إناثاً فيما يتعلــق بالمكــان

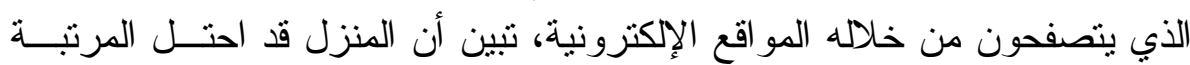

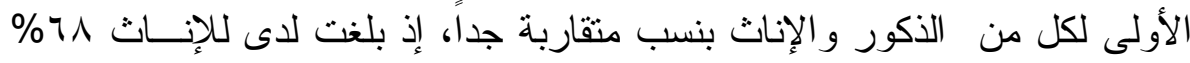

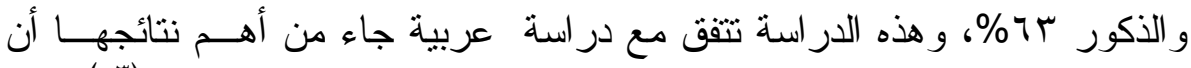

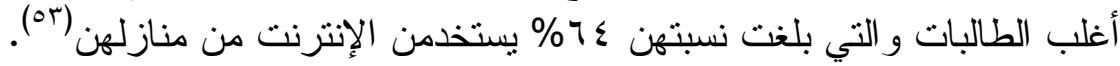
رابعًا : مقارنة المواقع الإكترونية الأكثر تصفحاً ومتابعة من قبل الطلاب ذكــوراً وإناثاً:

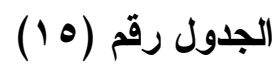

\begin{tabular}{|c|c|c|c|c|}
\hline المئوية & الإناث & المئوية & الأكور & الموقع \\
\hline$\% 79$ & 79 & $\% 71$ & 71 & Face Book \\
\hline$\% r$ & $r$ & $\% \leq$ & $\varepsilon$ & Utube \\
\hline$\%$ Y & $r \wedge$ & $\% r r$ & rr & Google \\
\hline- & - & $\% r$ & $\mu$ & Yahoo \\
\hline$\% 1 \ldots$ & $1 \ldots$ & $\% 1 \ldots$ & $1 \ldots$ & جموع \\
\hline
\end{tabular}

يِلاحظ من الجدول رقم (10) أن موقع Face Book أكثر الو اقع الالكترونية

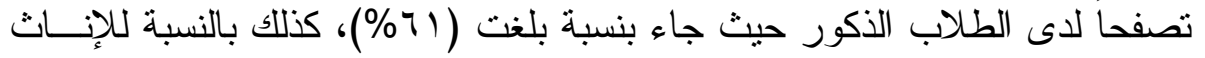

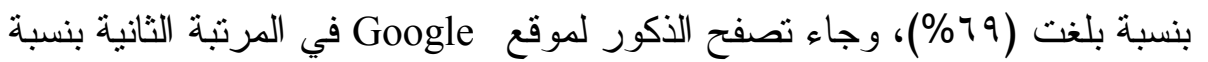

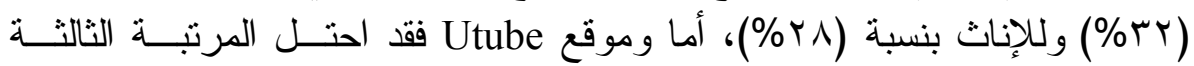

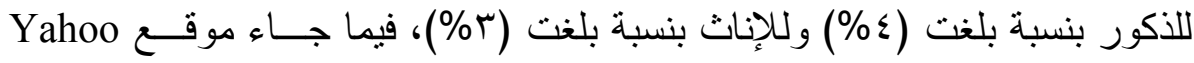

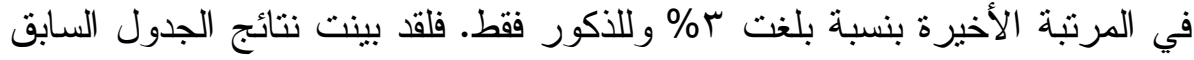

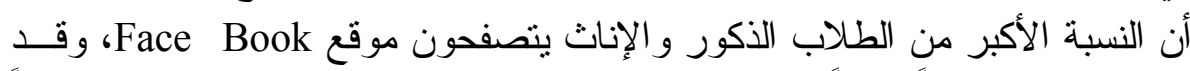

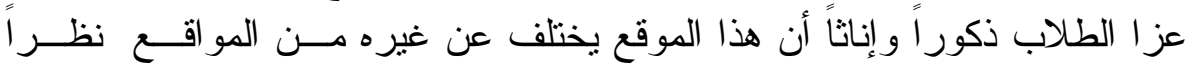

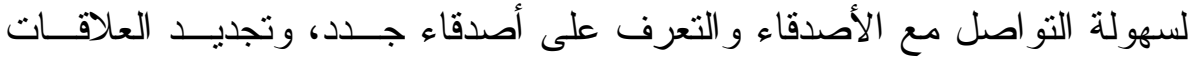


بأصدقاء الماضي ومشاهدة الصور ومو اكبة ما يجرى على الساحة الدولية وإِـــاء

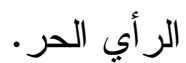

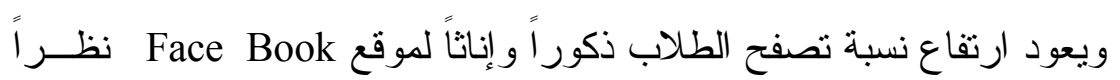

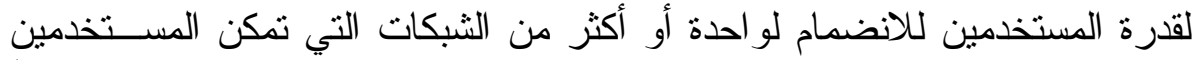

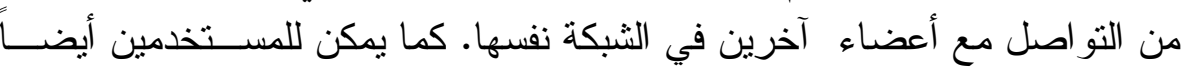

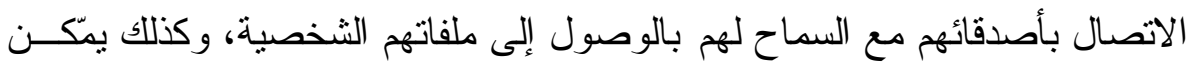

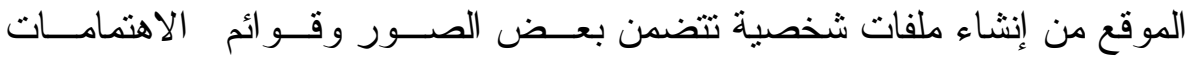

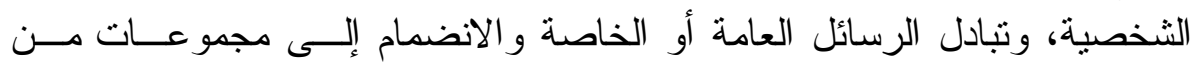

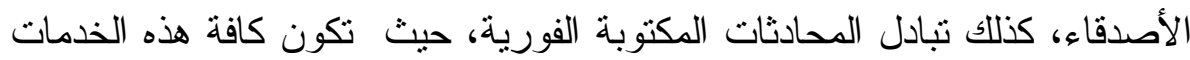

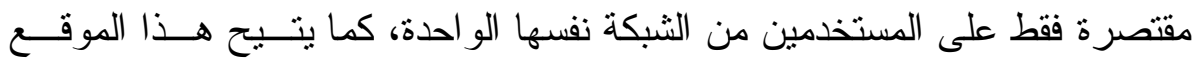

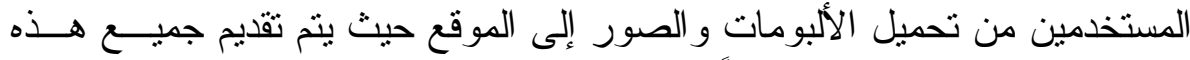

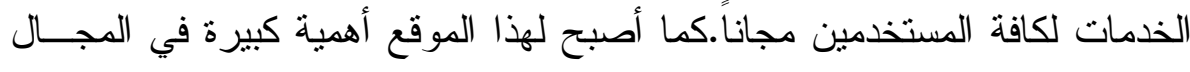

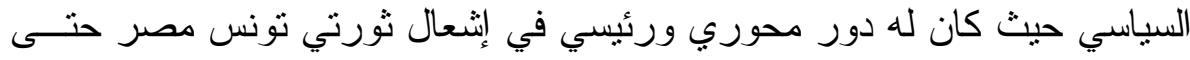

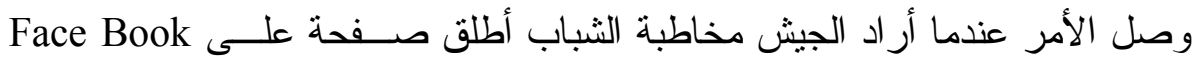
حيث أصبح يطلق على هذا الموقع الإعلام الجديد.

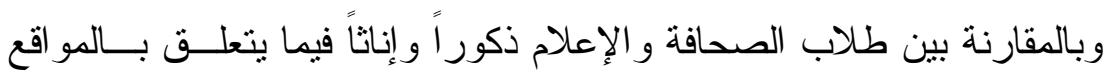

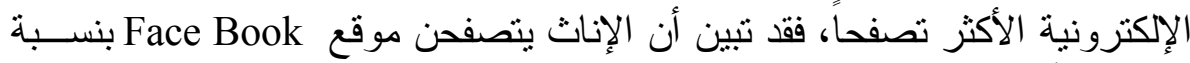

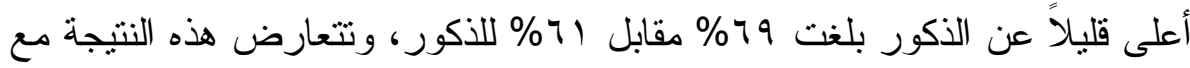

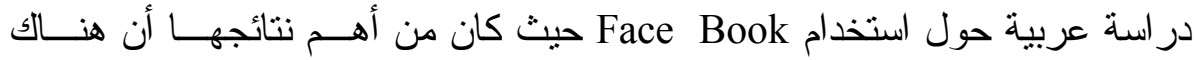

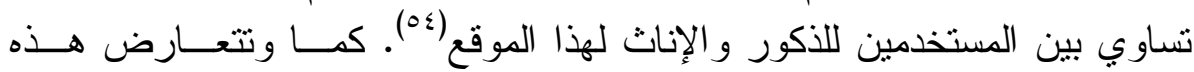

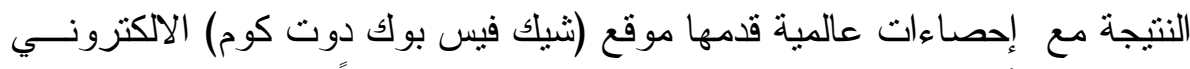

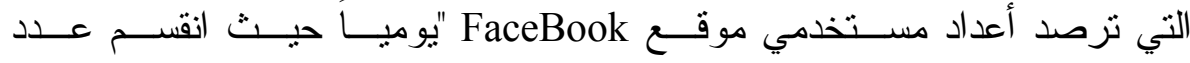

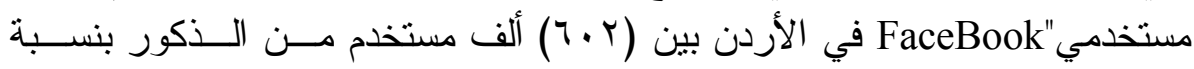

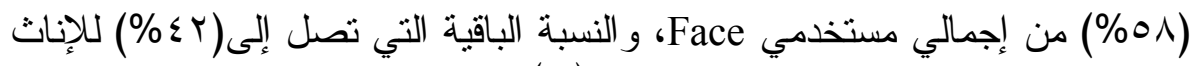

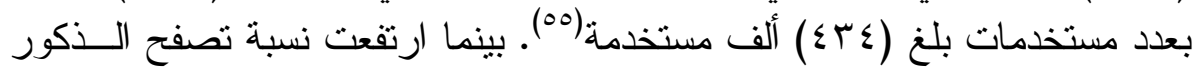

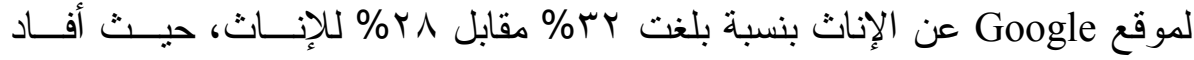

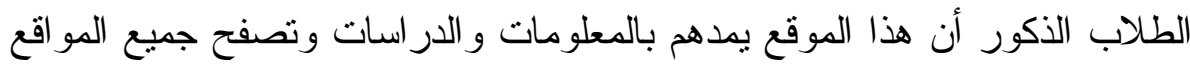
الإخبارية بسر عة ويسر . 
خامساً: اعتبار المواقع الإكترونية للطلاب ذكورًا وإناثًا مصدرًا للمعلومات:

(الجدول رقم (17) - (17)

\begin{tabular}{|c|c|c|c|c|}
\hline النسبة المئوية & تكرار الإناث & النسبة المئوية & تكرار الأكور & المفردة \\
\hline$\% \curlyvee \wedge$ & 71 & $\% \vee \varepsilon$ & $V \varepsilon$ & نعم \\
\hline$\%$ Ir & Ir & $\% 9$ & 9 & y \\
\hline$\% r$. & $r$. & $\% \backslash \vee$ & IV & أحياناً \\
\hline$\% 1 \ldots$ & $1 \ldots$ & $\% 1 \ldots$ & $1 \ldots$ & المجموع \\
\hline
\end{tabular}

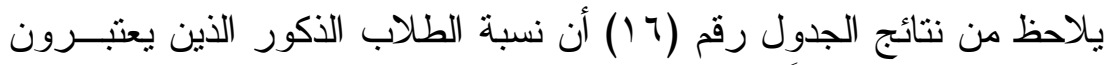

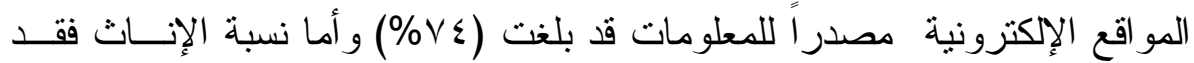

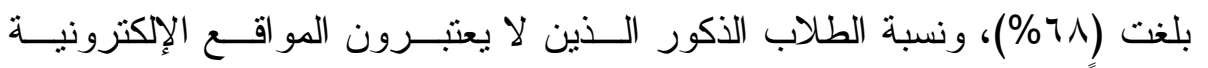

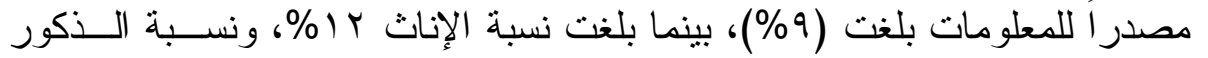

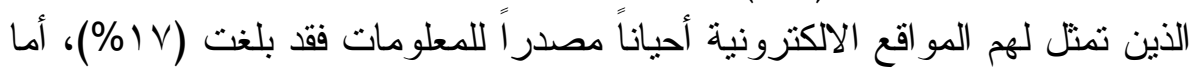

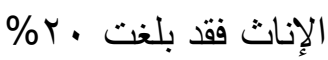

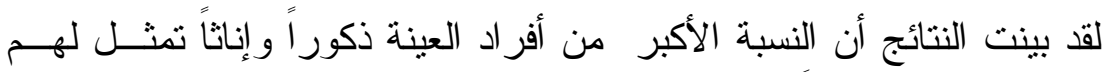

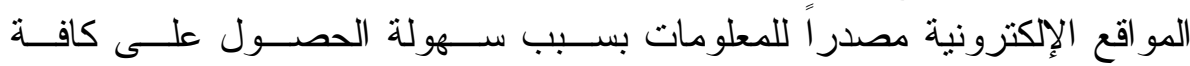

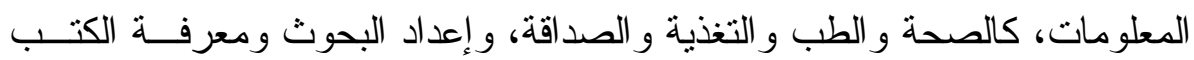
الحديثة، و الحصول كال على الأخبار من مو اقع الإخبارية و والهير ها من البيانات.

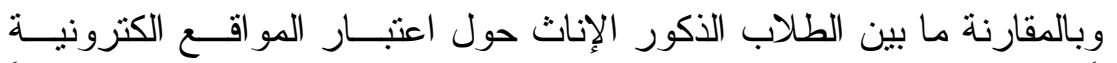

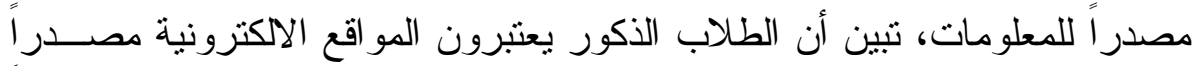

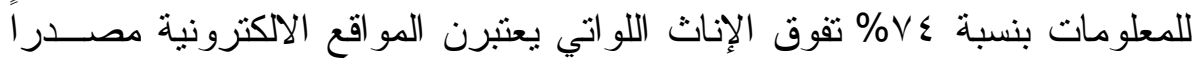

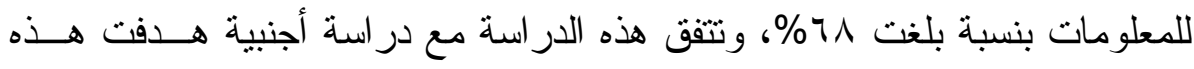

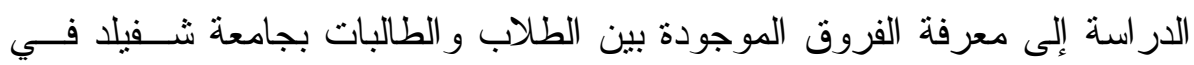

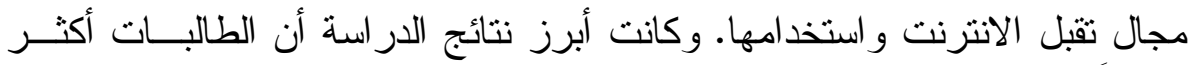

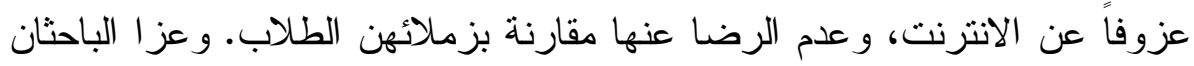

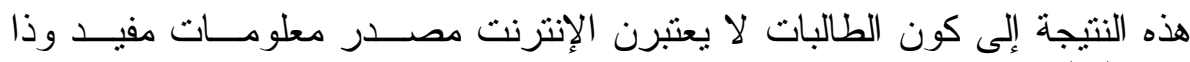

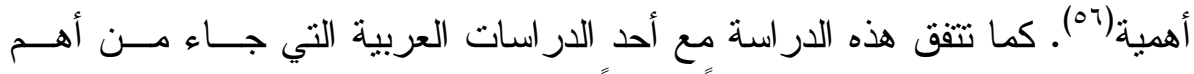

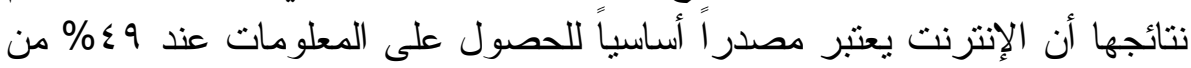

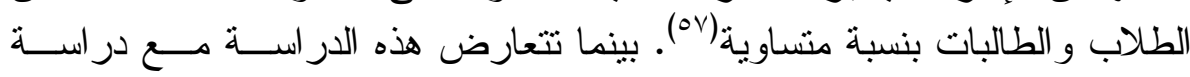




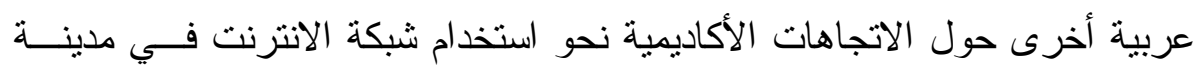

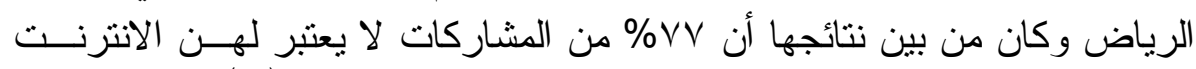

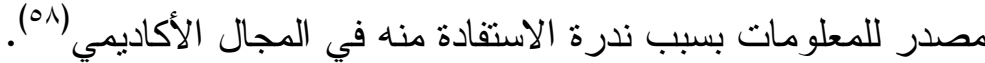

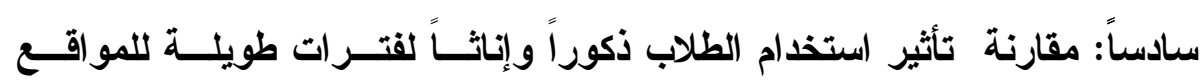
الإكترونية على تحصيلهم الار اسي:

(الجدول رقم (IV)

\begin{tabular}{|c|c|c|c|c|}
\hline النسبة المئوية & تكرار الإناث & النسبة المئوية & تكرار الأكور & المفردة \\
\hline$\%$ \% & $r \varepsilon$ & $\%$ rv & TV & نعم \\
\hline$\%$ \% & $r q$ & $\% r q$ & rq & $y$ \\
\hline$\% r v$ & $r v$ & $\%$ \% & $\Gamma \varepsilon$ & أحياناً \\
\hline$\% 1 \ldots$ & $1 \ldots$ & $\% 1 \ldots$ & $1 \ldots$ & المجمو ع \\
\hline
\end{tabular}

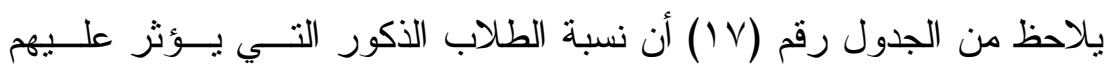

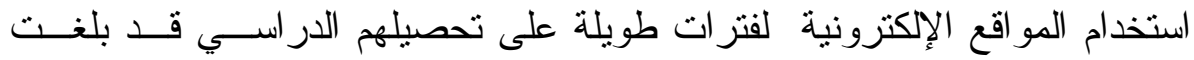

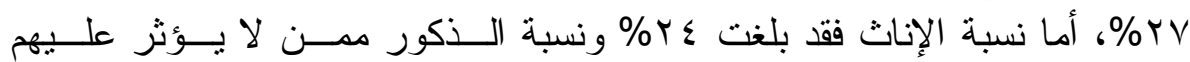

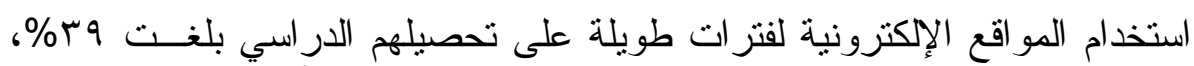

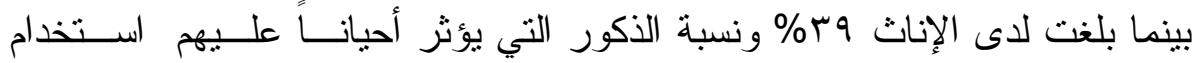

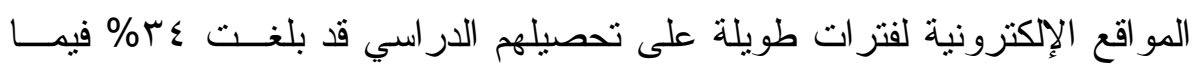

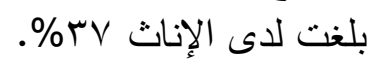

فقد بينت نتائج الجدول السابق أن النسبة الأكبر من الطلاب الذكور و الإنـاث الإناث

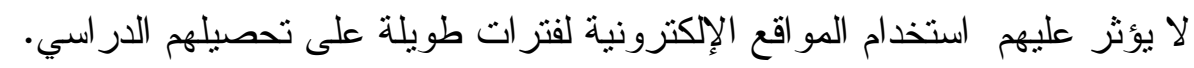

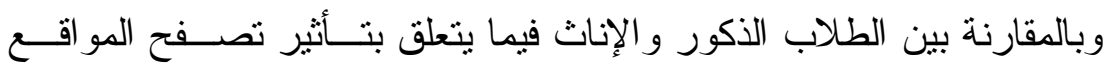

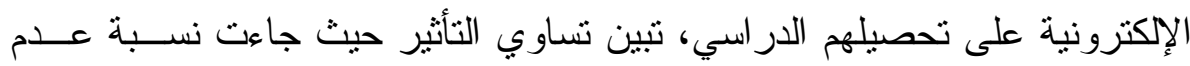

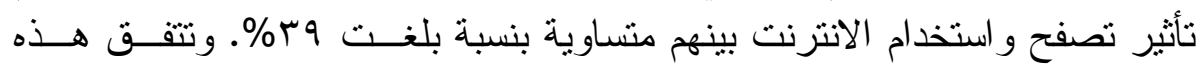

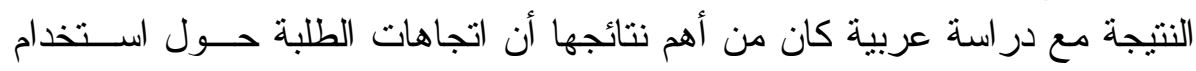

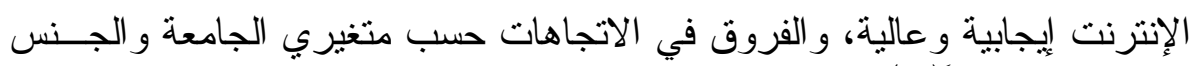
غبر دالة إحصائياً (09). 


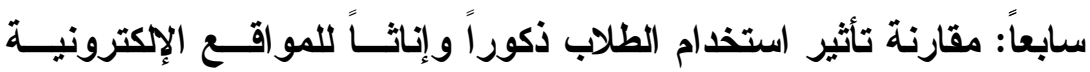
علاقاتهم الاجتماعية: عاته

الجدول رقم (1)

\begin{tabular}{|c|c|c|c|c|}
\hline المئوية & تكرار & المئوية & الكرار & المفردة \\
\hline$\%$ \% & rq & $\% \circ r$ & or & نعم \\
\hline$\%$ rᄉ & rᄉ & $\%$ rq & rq & $y$ \\
\hline$\%$ & rr & $\% 19$ & 19 & أحياناً \\
\hline$\% 1 \ldots$ & $1 \ldots$ & $\% 1 \ldots$ & $1 \ldots$ & المجمو ع \\
\hline
\end{tabular}

يلاحظ من الجدول رقم (1) (1) أن نسبة الطلاب الذكور الذي يؤثر استخدامهم

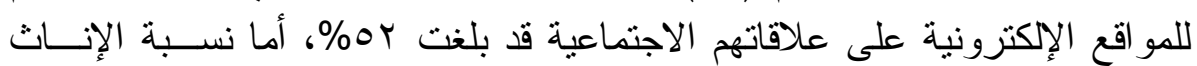

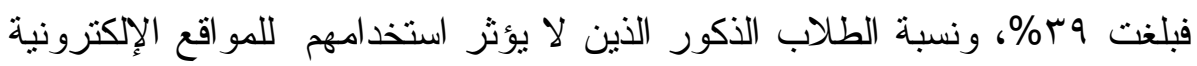

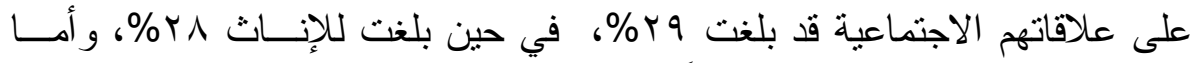

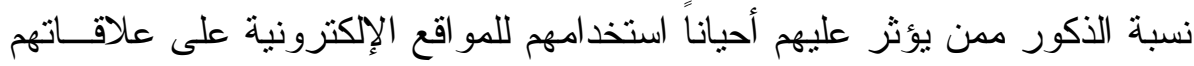

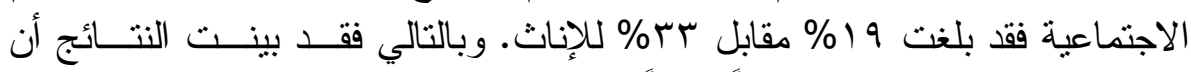

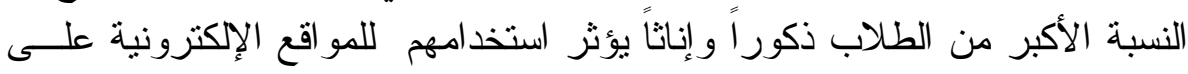
علاقاتهم الاجتماعية.

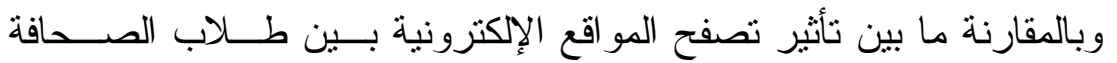

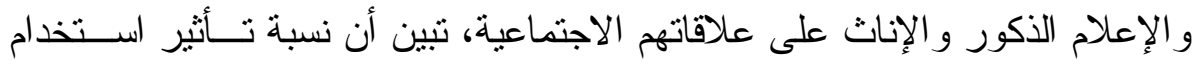

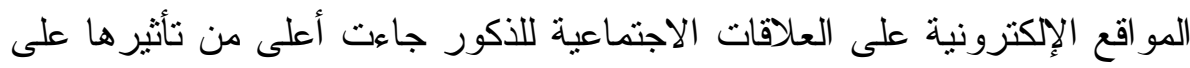

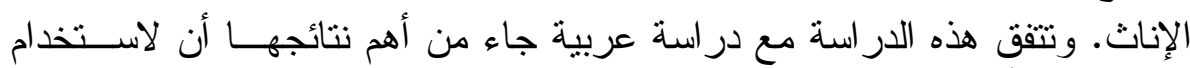

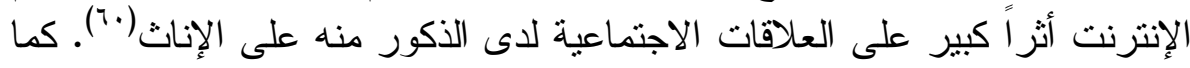

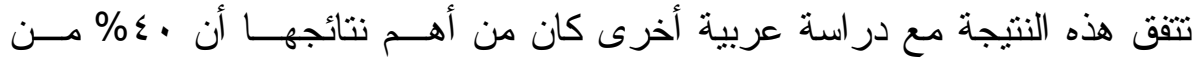

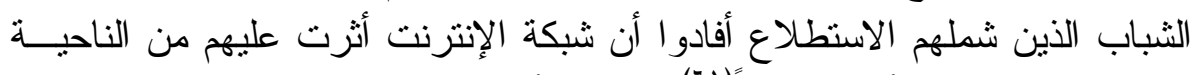

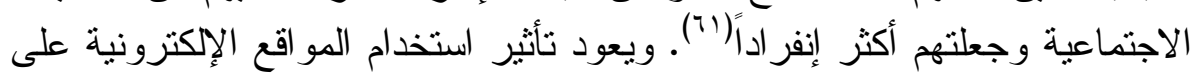

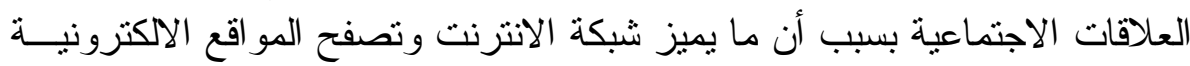

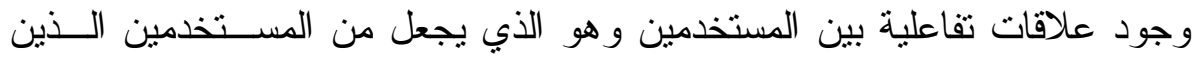

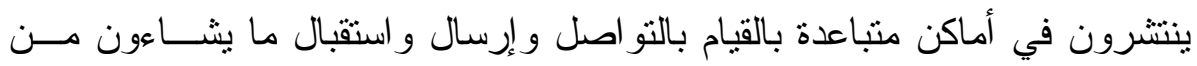


المعلومات. وبالتالي فقد أثرت هذه التكنولوجيا الحديثة على كثيــر مــن النــواحي واحي

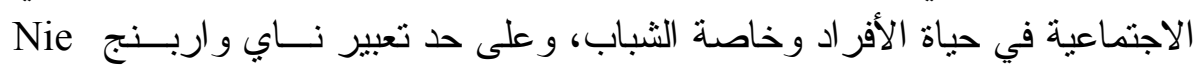
and Erbing كيفية عمل الناس ومكان عملهم، ومقداره، ومع من يعملون ويتفاعلون. فتكنولوجيا

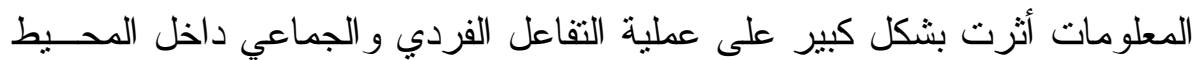
الأسري وداخل المحيط الاجتماعي للمجتمع الأكبر (rآ).

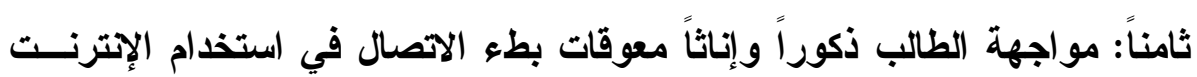

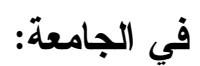

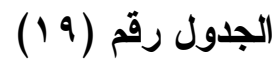

\begin{tabular}{|c|c|c|c|c|}
\hline المئوية & الإناث & المئوية & الأكور & المفردة \\
\hline$\% \circ r$ & or & $\% \leq r$ & $\varepsilon r$ & نعم \\
\hline$\% \backslash \wedge$ & 11 & $\%$ \% & rq & $y$ \\
\hline$\%$ \%q & rq & \%rr & rT & أحياناً \\
\hline$\% 1 \ldots$ & $1 \ldots$ & $\% 1 \ldots$ & $1 \ldots$ & المجمو ع \\
\hline
\end{tabular}

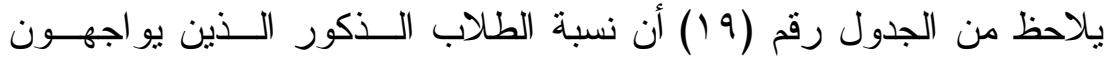

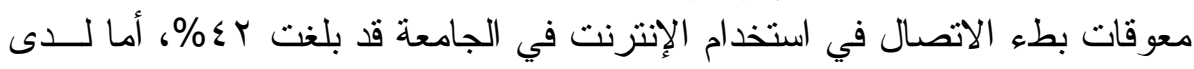

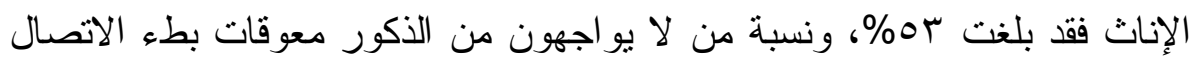

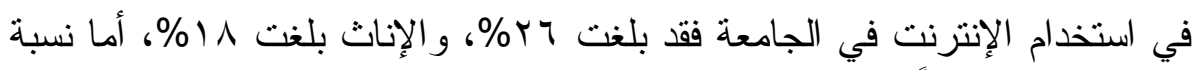

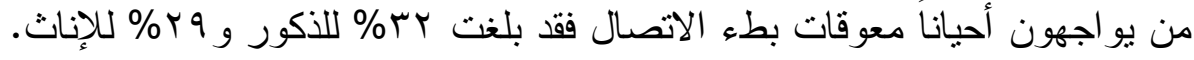

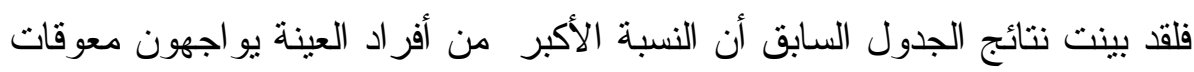

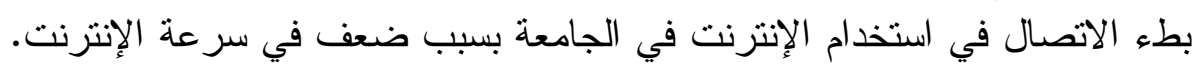

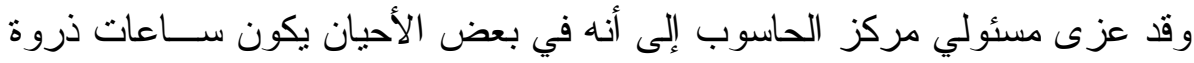

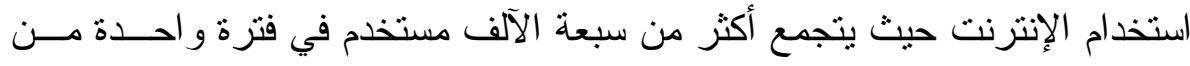

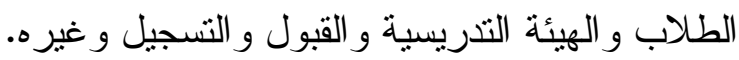

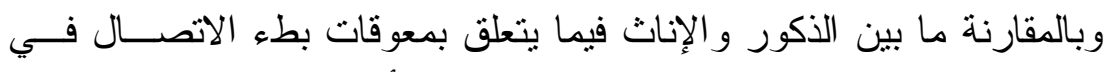

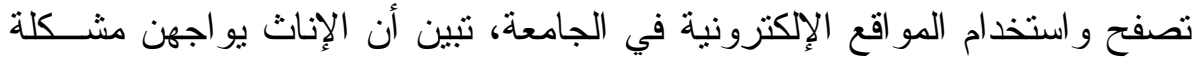

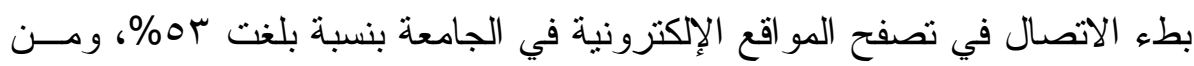




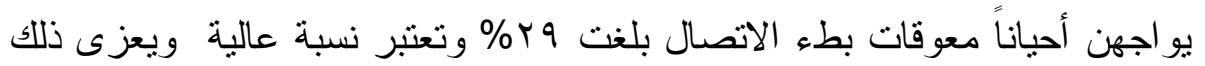

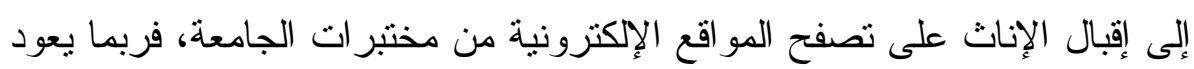

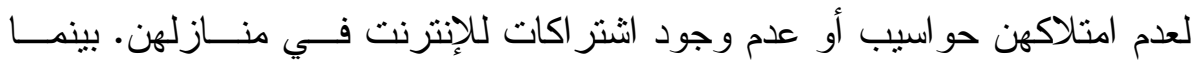

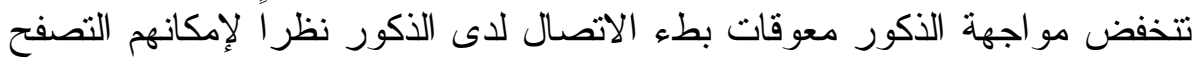
من أي مكان سواء المنزل أو مقاهي الانترنت.

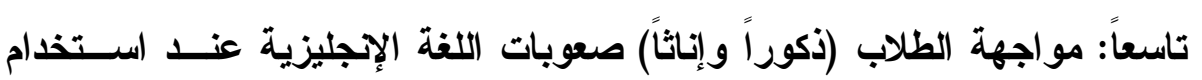

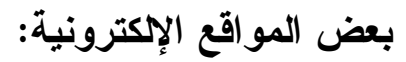

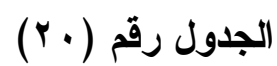

\begin{tabular}{|c|c|c|c|c|}
\hline المئوية & تكرار الإِاث & المئوية & تلكرار & المفردة \\
\hline$\%$ \% & r & $\%$ \%q & rq & نعم \\
\hline$\% r v$ & rv & $\% r r$ & rr & $y$ \\
\hline$\%$ \%r & rT & $\%$ \% & $\varepsilon 9$ & أحياناً \\
\hline$\% 1 \ldots$ & $1 \ldots$ & $\% 1 \ldots$ & $1 \ldots$ & المجموع \\
\hline
\end{tabular}

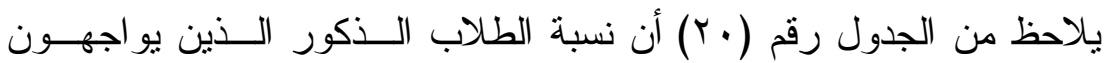

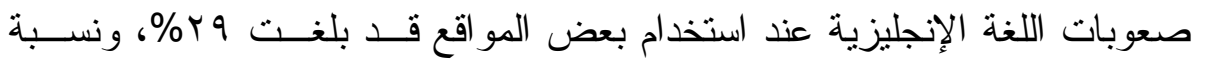

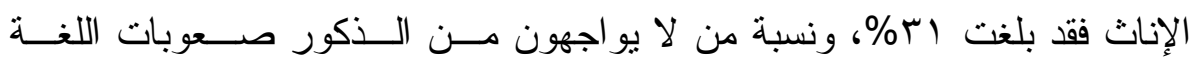

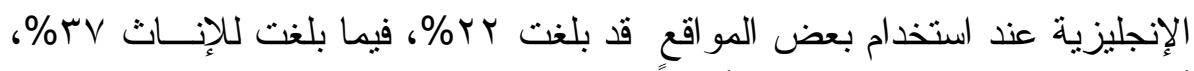

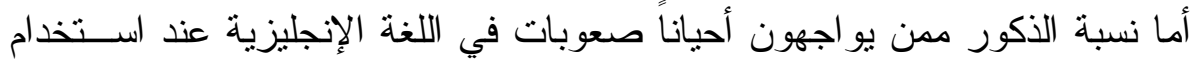

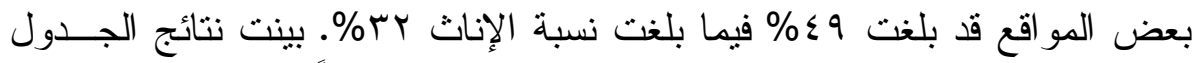

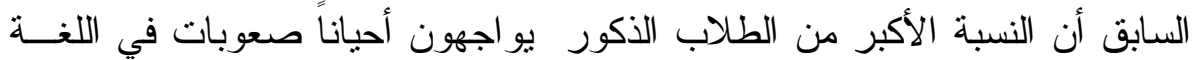

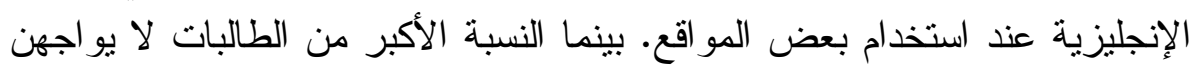
صعوبات في اللغة الإنجليزية عند استخدام بعض لئن المواقع.

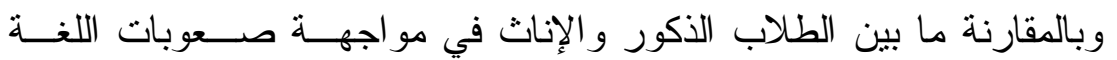

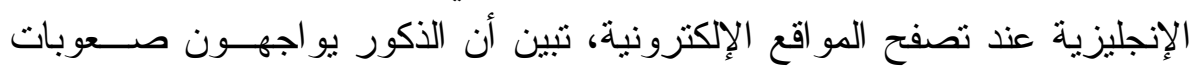

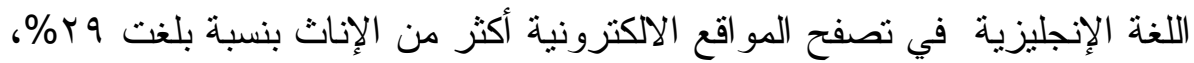

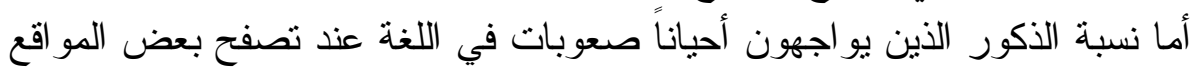
قد بلغت 9٪\% ل لصالح الإناث. 


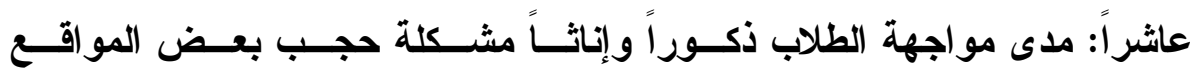

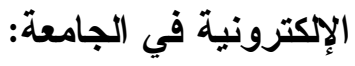

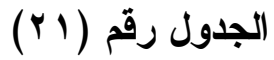

\begin{tabular}{|c|c|c|c|c|}
\hline المئوية & الإناث & المئوية & الكرار & المفردة \\
\hline$\% \circ \leqslant$ & os & \%тr & r & نعم \\
\hline$\% \backslash \wedge$ & 11 & $\% r$. & $r$. & $y$ \\
\hline$\%$ \% & rᄉ & $\% \backslash \mathrm{V}$ & IV & أحياناً \\
\hline$\% 1 \ldots$ & $1 \ldots$ & $\% 1 \ldots$ & $1 \ldots$ & المجمو ع \\
\hline
\end{tabular}

يلاحظ من الجدول رقم (Y) أن نسبة الطلاب الذكور الذين يو اجهون مشكلة

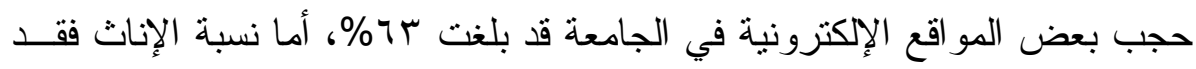

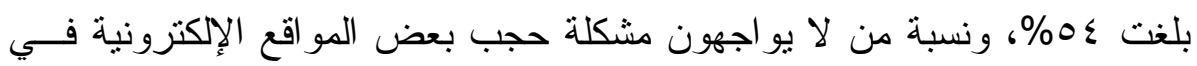

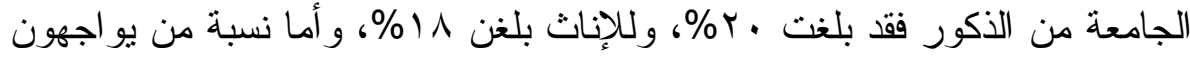

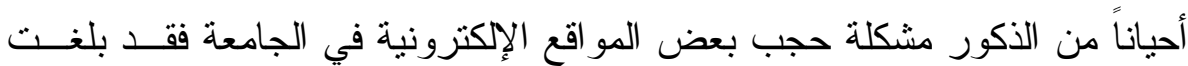

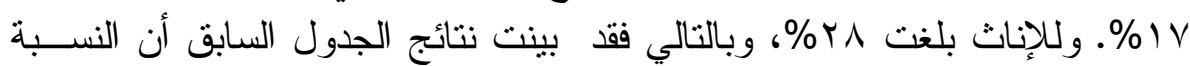

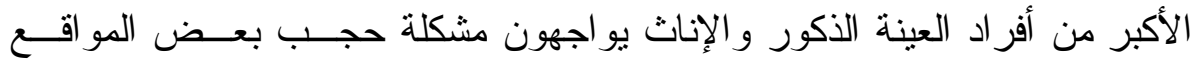

$$
\text { الإلكترونية في الجامعة. }
$$

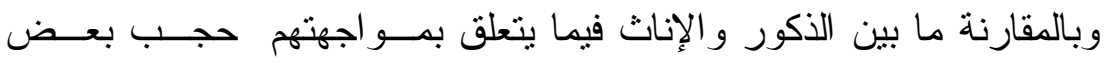

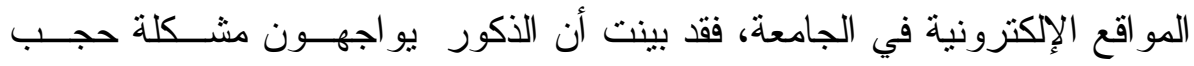

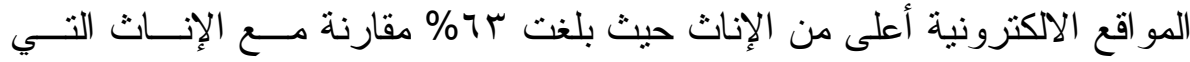

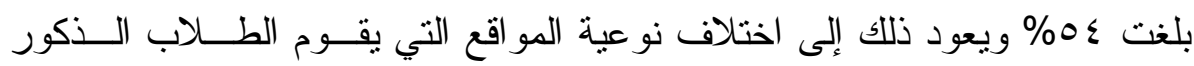
بتصفحها والتي تختلف عن اهتمامات الإناث. ج) خلاصة الار استة: خرجت هذه الدر اسة بعدد من النتائج و التي جاءت بناء على محددات الدر اسة

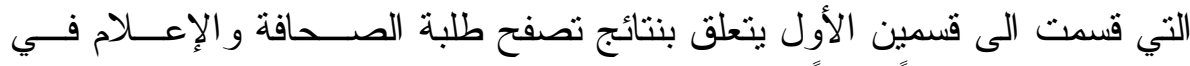

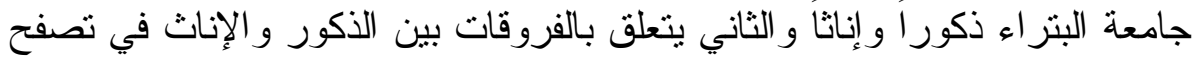

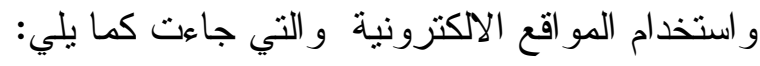


( ) النتائج المتعلقة بتصفح جميع طلاب قسم الصحافة والإعلام (ذكــوراً و إناتـاً) للمواقع الإكترونية:

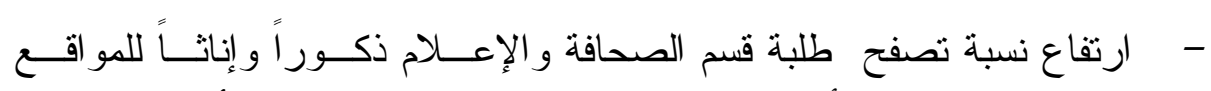

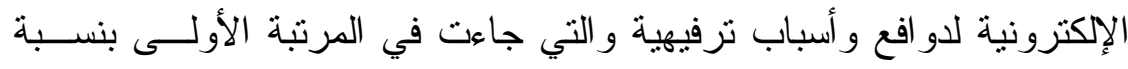

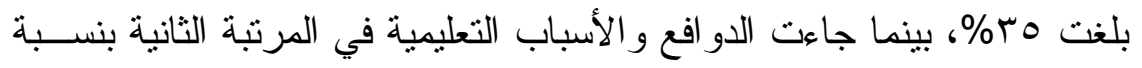

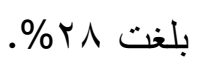
يقضي طلاب الصحافة و الإعلام وذكور اً و إناثاً مدة ثلاث ساعات في تصــفح

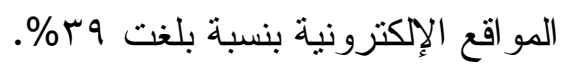

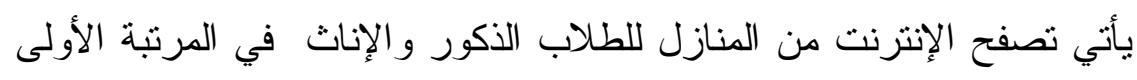

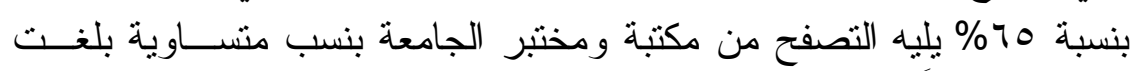

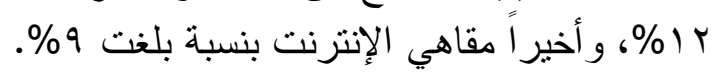

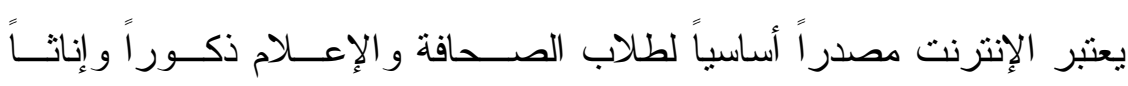

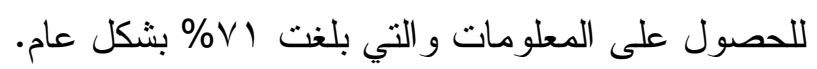

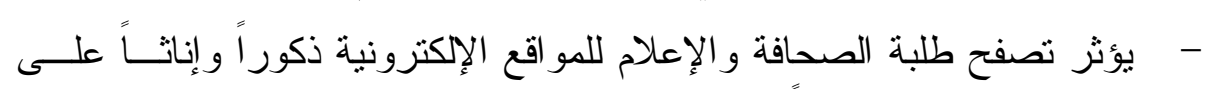

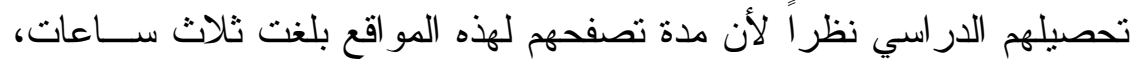

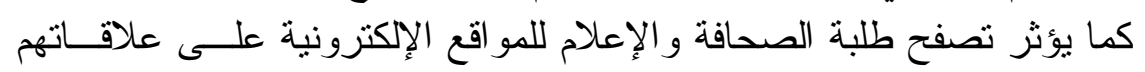
الاجتماعية.

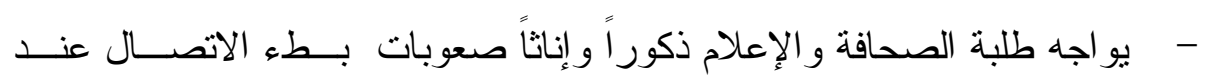

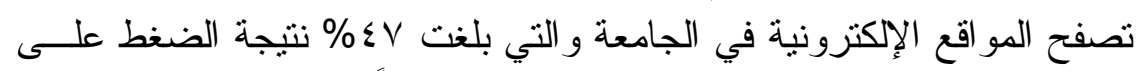

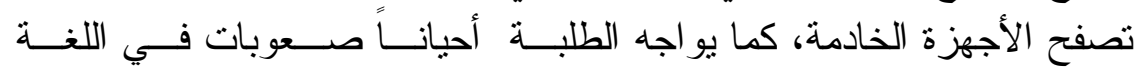

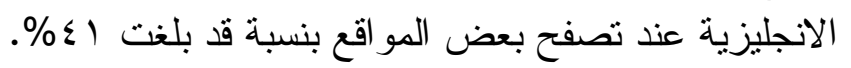

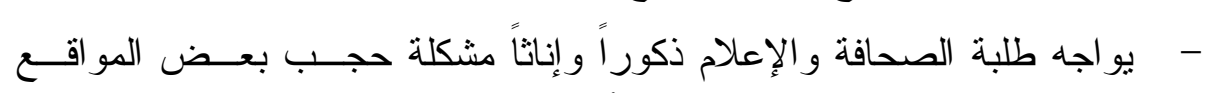

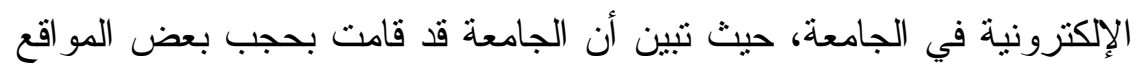

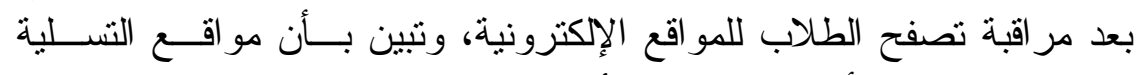

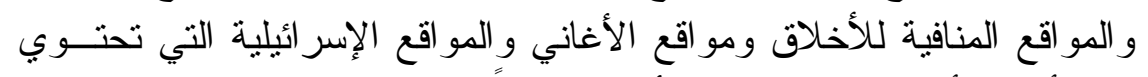

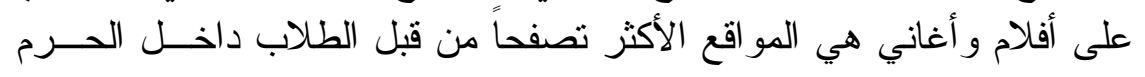
الجامعي. 
r) النتائج المتعلقة بالفروقات بين تصفح كل مـن الــكور والإسـاث ل للمواقــع

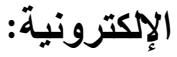

\section{1- دوافع تصفح المو اقع الإكترونية لاى الجنسين:}

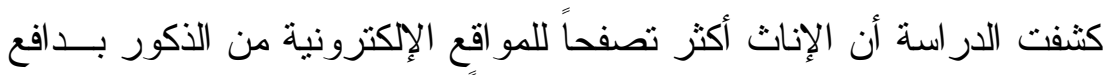

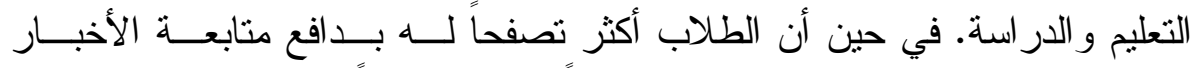

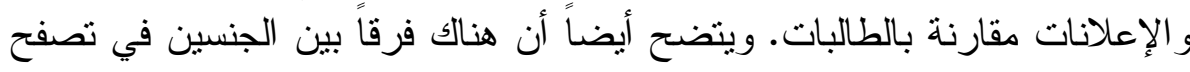

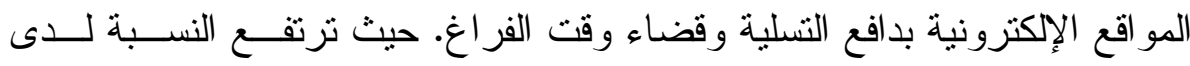

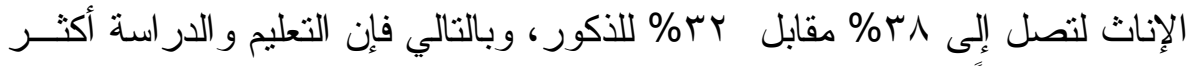

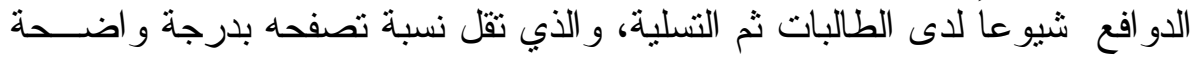

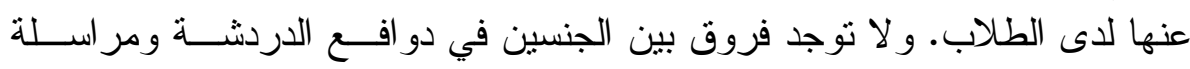

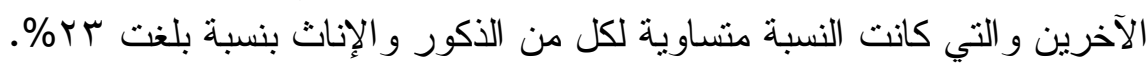

\section{r- المدة التي يقضيها كلا الجنسين في تصفح المواقع الإكترونية:}

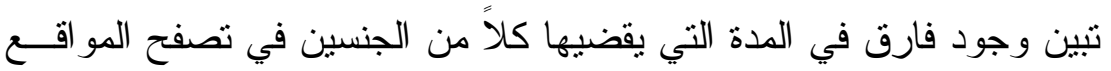

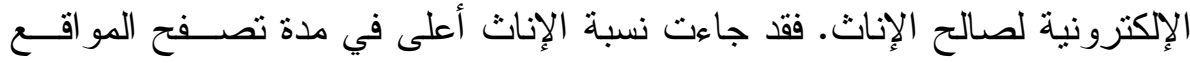

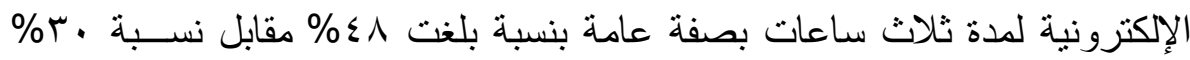

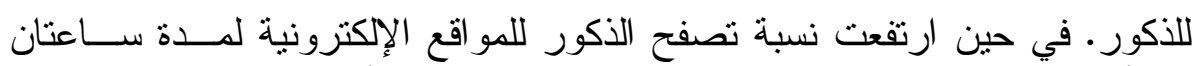

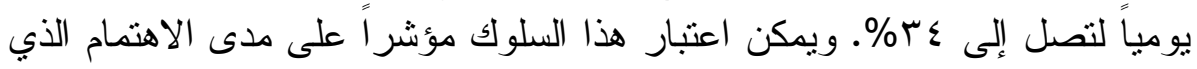

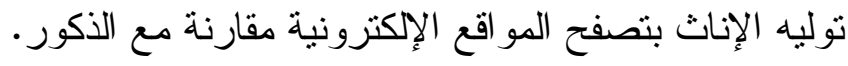

r- المكان الأي يقوم من خلاله كلا الجنسين بتصفح المواقع الإكترونية:

كثفت الدر اسة بصفة عامة عدم وجود فروق بين الجنسين في اختيار المكان

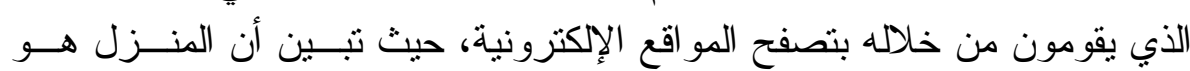

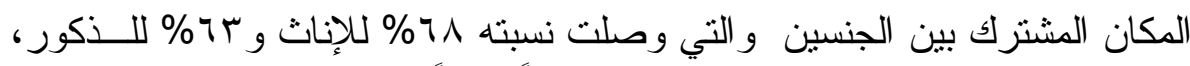

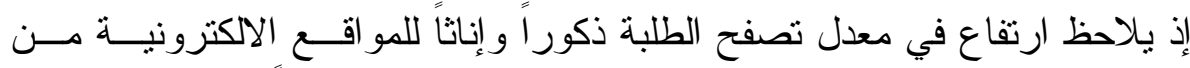

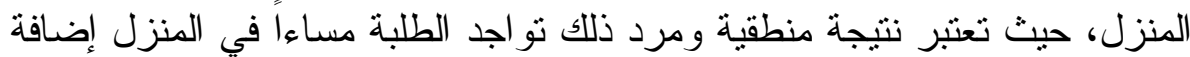

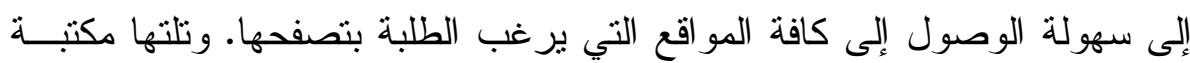

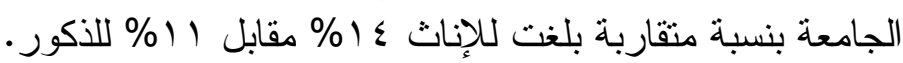




\section{؛ - المواقع الأكثر تصفحاً ومتابعةً من قبل كلا الجنسين:}

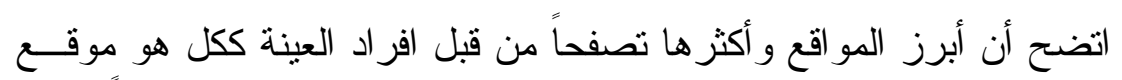
Face Book

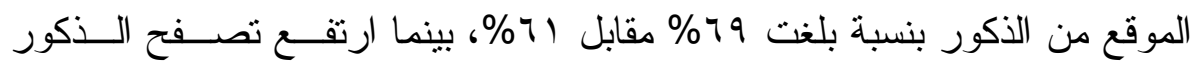

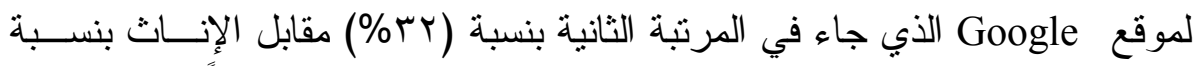

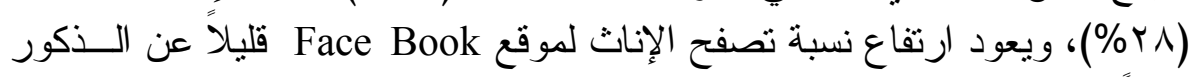

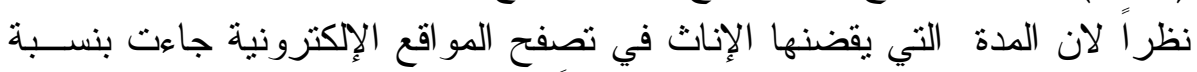

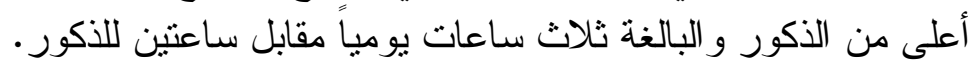
ه - اعتبار المواقع الإكترونية مصدراً للمطلومات لكلا الجنسين:

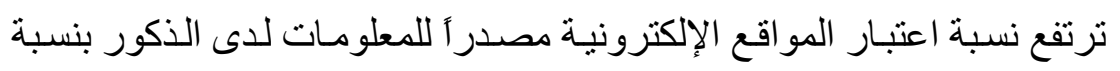

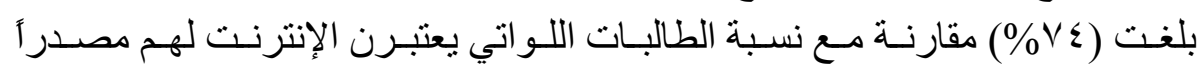

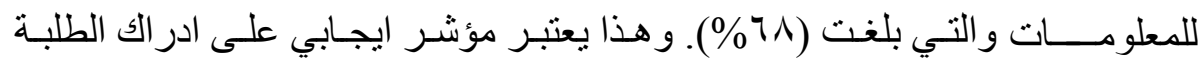

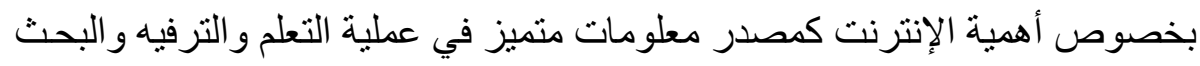

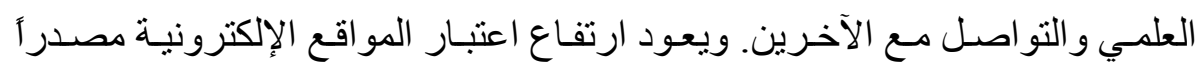

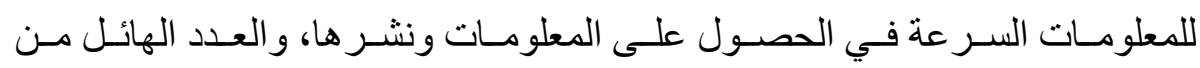

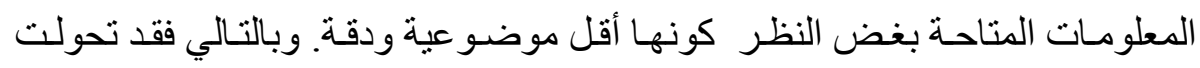

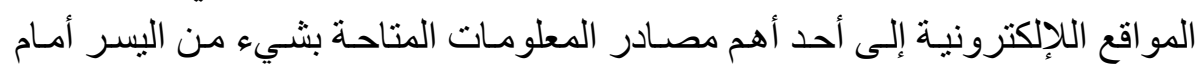

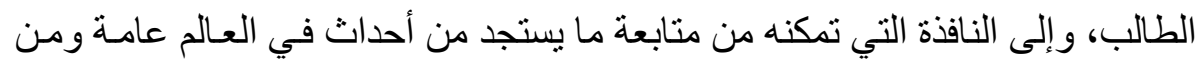

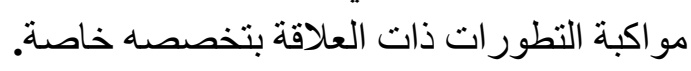

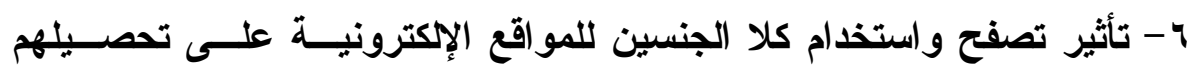

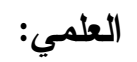
جاءت نتائج الدراسة منساوية ما بين الطلبة ذكوراً وإناثاً حول عـدم تــأثير

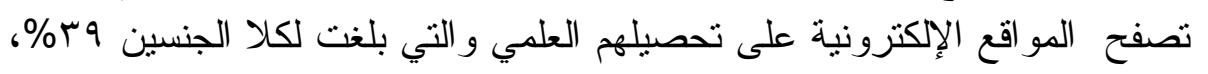

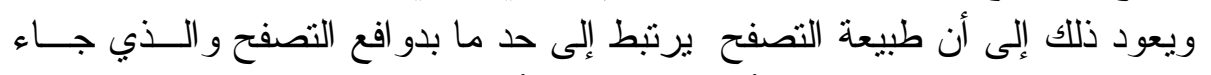

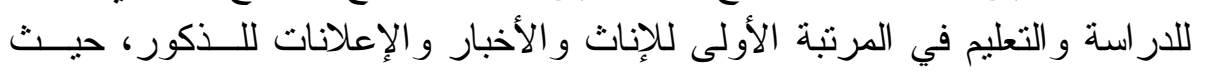

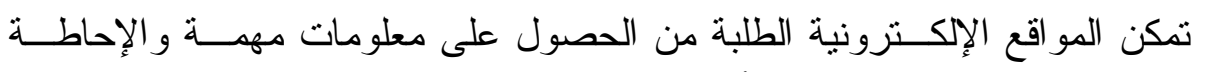

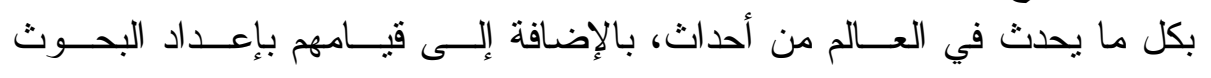


و الو اجبات المطلوبة منهـــم من خلال الاستعانة بالمعلومات المتاحة فــي المواقــع

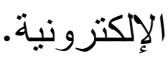

V - تأثير تصفح كلا الجنسين للمو اقع الإكترونية على علاقاتهم الاجتماعية:

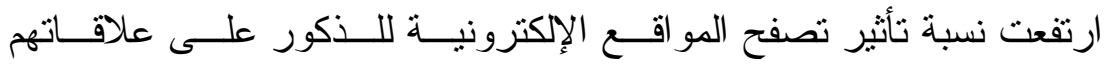

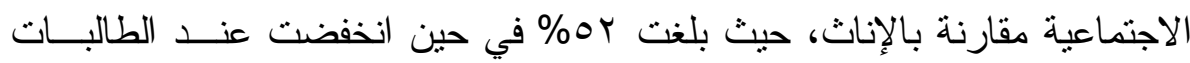

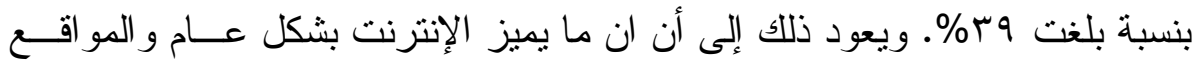

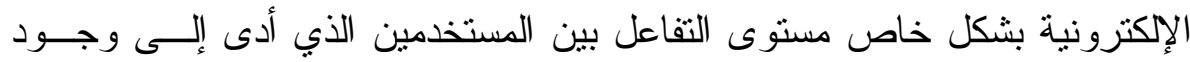

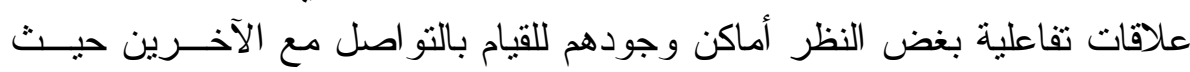

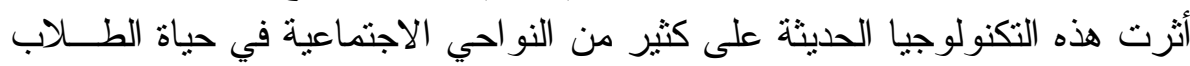

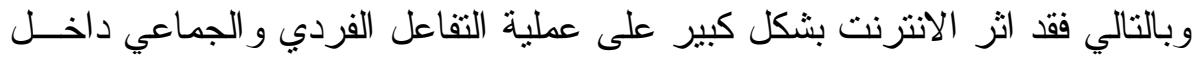

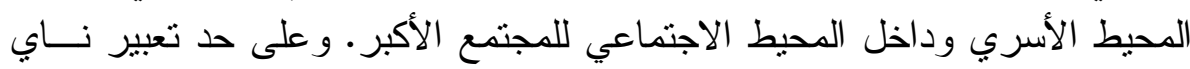

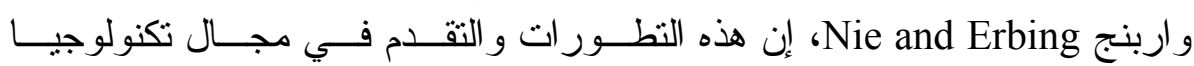

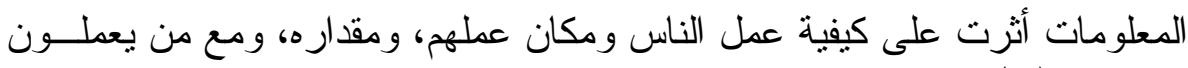
ويتفاعلون (Tir). (الترن)

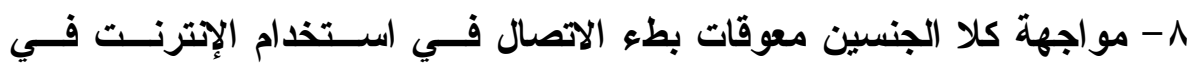

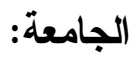

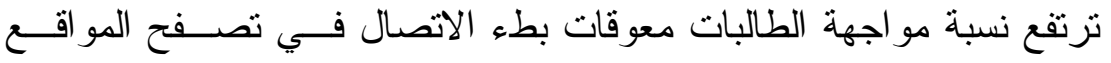

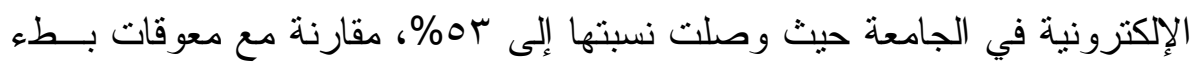

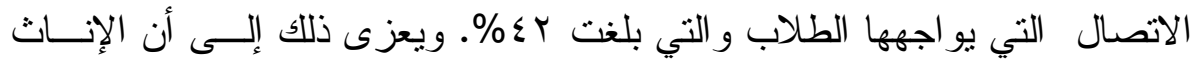

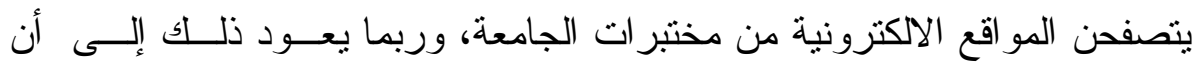

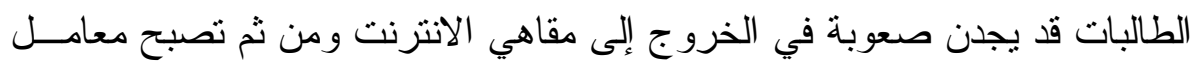

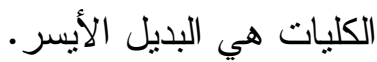

9- مواجهة كلا الجنسين صعوبات اللغة الاجليزية عند استخدام بعض المواقــع

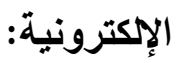

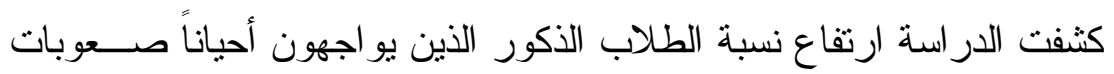

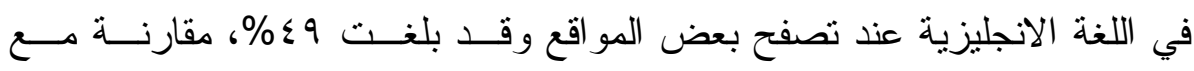

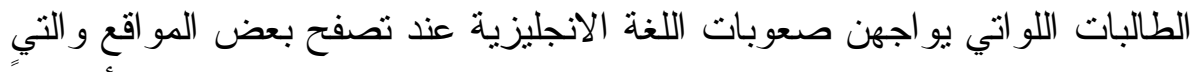

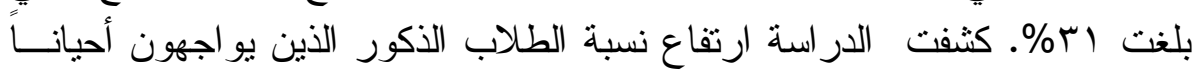




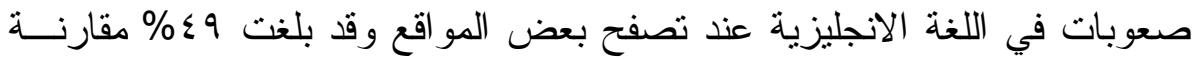

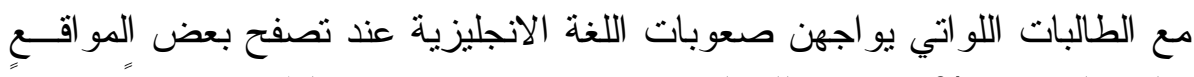

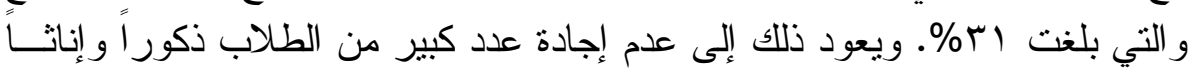

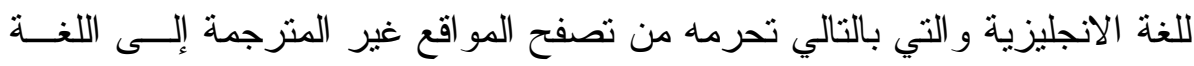

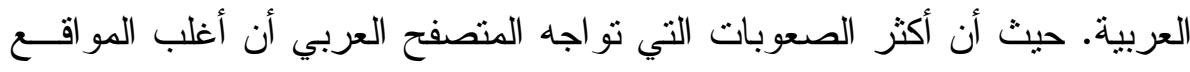

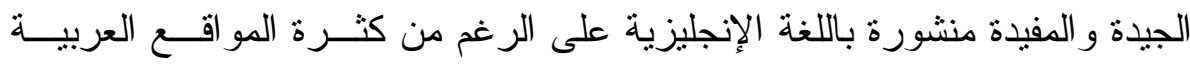

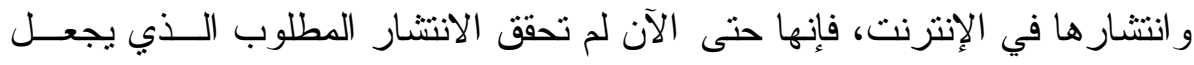

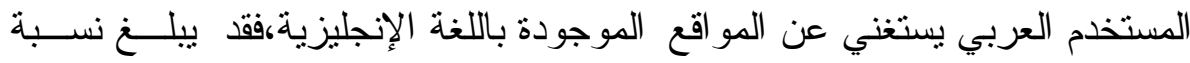
عدد الصفحات العربية إلى بقية صفحات الويب حو الي ال (\% فقط. • 1- مواجهة الطلاب الأكور والإحاث مشكلة حجب بعض المواقع الإكترونية في

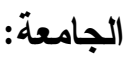

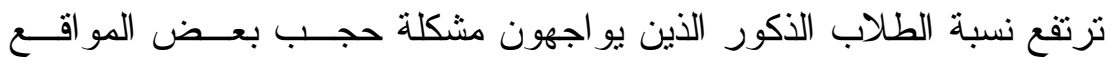

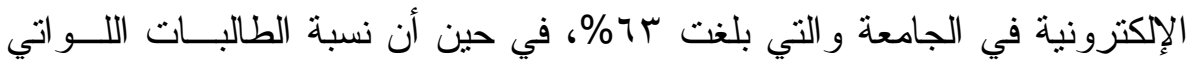

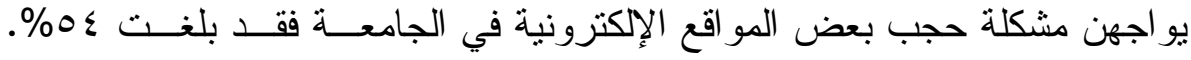

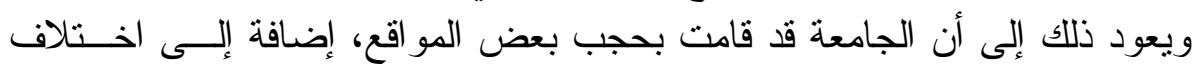

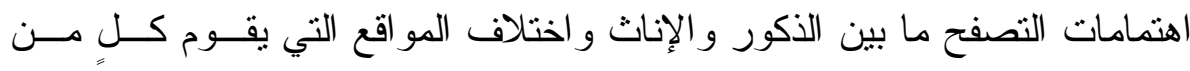
الأكور و الإناث بتصفحها. د) توصيات الدر اسة: يعتبر البحث في واقع تصفح و استخدام طلبة الصـــحافة و الإعــلام حــديث

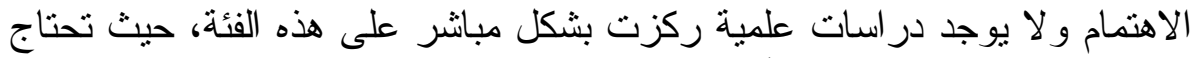
إلى اهتمام أوسع و أعمق نظراً لأن هذه الثريحة من رلت الطلبة سيكونون مر آة الإعلام

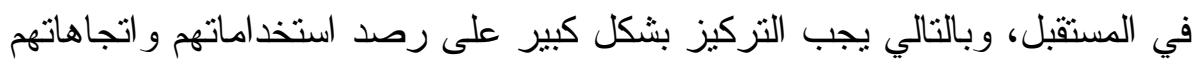

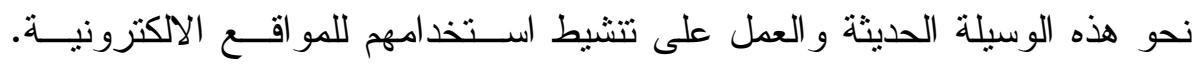

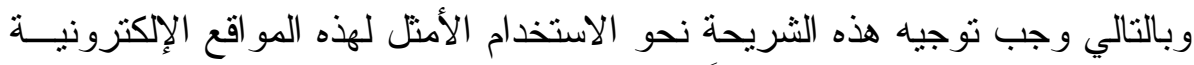

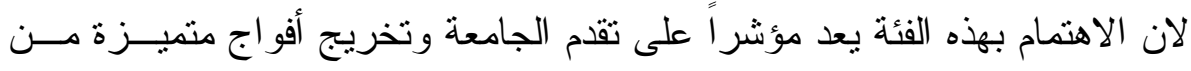
طلبة الصحافة و الإعلام.

وقد خلصت هذه الدر اسة إلى بعض التوصيات الهامة التي نزيد من فعاليــة تصفح طلبة الصحافة و الإعلام في جامعة البتر اء للمو اقع الاككترونية: 
- توسيع نطاق تصفح الإنترنت في العملية التعليمية من جانــب أعضـــاء هيئــة

التدريس وطلاب قسم الصحافة و الإعلام و التوعية بالفو ائد التي يمكن تحقيقها.

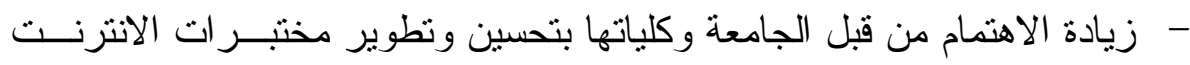

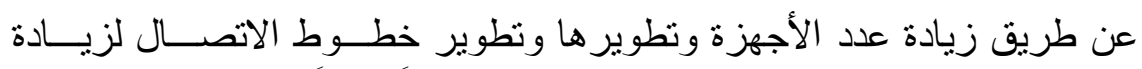

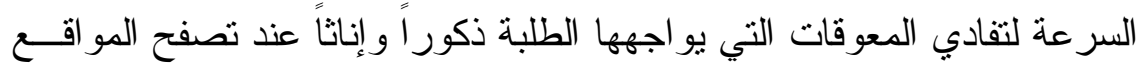
الإلكترونية.

- التركيز على المساقات المتعلقة باستخدامات المواقع الإلكترونية لطلبة الصحافة

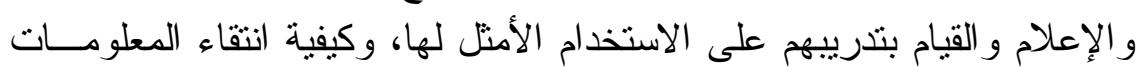

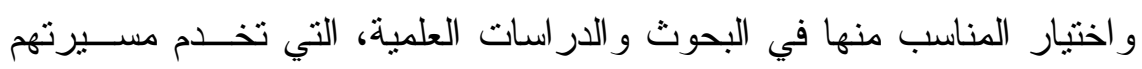

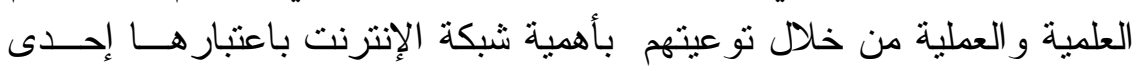

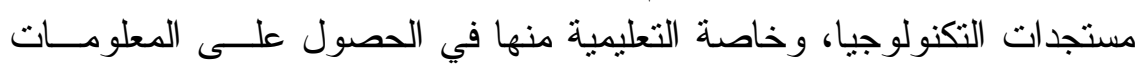
العلمية المتنو عة.

- أهمية إجر اء در اسات مستقبلية شاملة لطلبة الصحافة و الأعلام نظر اً لانتشــار

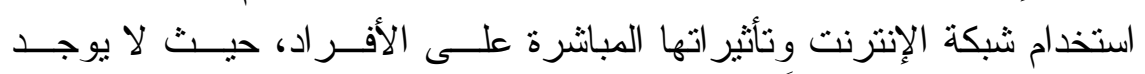

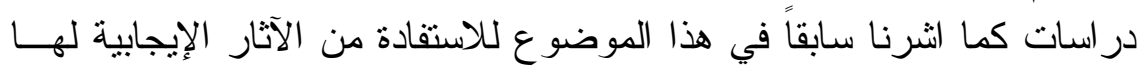
على طلبة الصحافة و الإعلام. 


$$
\begin{aligned}
& \text { المر اجن }
\end{aligned}
$$

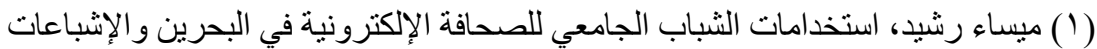

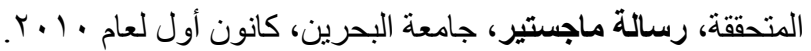

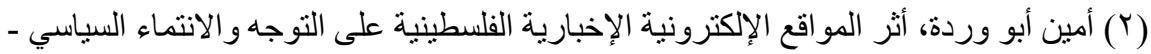

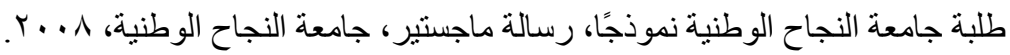

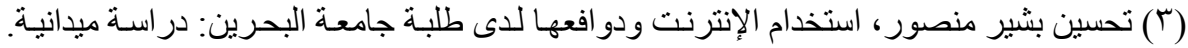

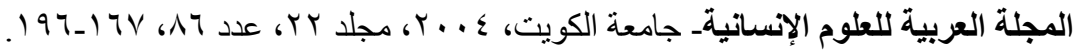

$$
\begin{aligned}
& \text { (ع) موفق عبد الله أحمد البطر ان: واقع استخدام الإنترنت في الجامعات الأردنية الخاصة في منطقة }
\end{aligned}
$$

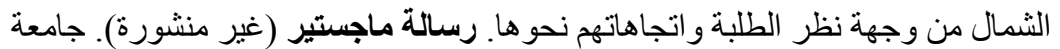

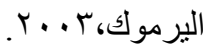

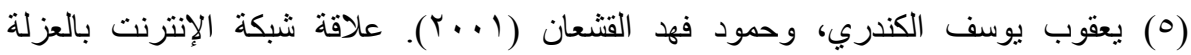

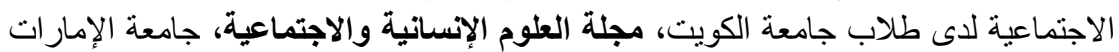

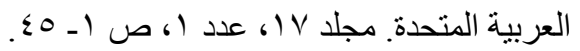

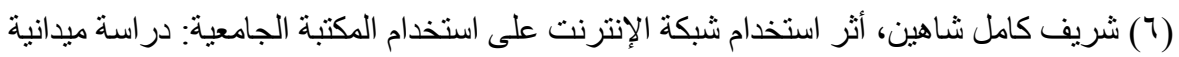

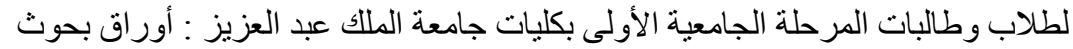

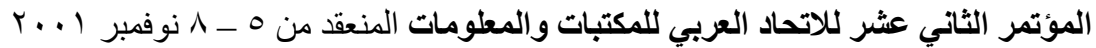

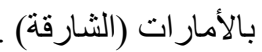

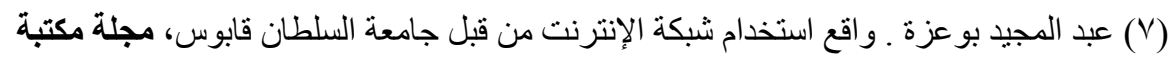

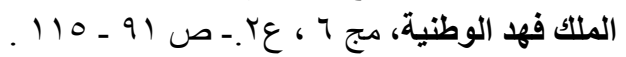

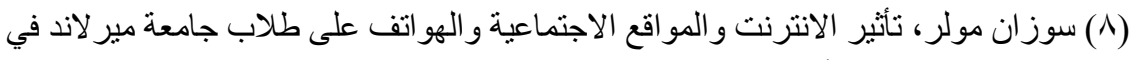

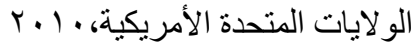

$$
\begin{aligned}
& r \cdot 1 \cdot . / \text { e-tech_and_gadgets }
\end{aligned}
$$

(9) PEW / Internet \& American Life Project . the Use of internet by students in Michigan State University, Retrieved in April 18,2004 from :

www.pew internet. org/releasees/release.asp?id $=5$

(10) Ferzetti, P.; Jaap, T.; King, T.; Tench, E. \& Thomas, J. (2004). The Effects of Internet Use on Students' GPA. Available at: www.psu.edu/dept/me dialab/research/ GP Anetuse .html. Accessed: April 16, 2004.

(11) Durndell, A. \& Haag, Z. (2002). Computer self-efficacy, computer anxiety, attitudes towards the Internet and reported experience with the 
Internet, by gender, in an East European sample. Computers-inHuman-Behavior. 18 (5), 521-535.

(12) Anderson, KInternet Use Among College Students: An Exploratory Study. Journal of American College Health, .(2001). 50 (1), 21-26.

(13) Duggan, A.; Hess, B.; Morgan, D.; Kim, S. \& Wilson, K. (1999). Measuring students' attitude toward educational use of the internet. Paper presented at the Annual Conference of the American Educational Research Association (Montreal, Canada, April 19-23, 1999). ERIC_NO: ED 429117.

(14) Tolpanen, Bradly P . a Survey of world wide web use by freshman English students : results and implications for bibliographic instruction .- Internet Reference Service Quarterly.- Vol. 4, No.4 (1999) pp.45- 63 .

(15) Perry, Timothy T. ,Internet use by university students : an 1) interdisciplinary study on three campuses / by Timothy T Perry, Leslie Anne Perry, Karen Hosacr-Curlin.- Journal of Internet Research, Electronic networking ، Applications and Policy - Vol. 8 , No. 2 (1998).- pp136-148 .

(16) Nigel ford, Dave miller, .Gender Differences in Internet perceptions and use Aslib proceedings, v.98, 7/8.(Jul-Aug. 1997).

(17) Murphy, Brian and Pascoe, Andrew. Using the Internet on a Business English Course, 1996. Eric, Accession Number ED 403743.

$$
\begin{aligned}
& \text { (1) (1) عماد الزهر اني، اثر استخدام شبكة الإنترنت على التحصيل الدراسي لطلاب مقرر تقنيات }
\end{aligned}
$$

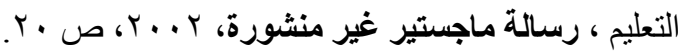

(9 9 ) و ائل الدهوري، المو اقع الإلكترونية للجامعات وموقع جامعة الفيوم، محاضرة جامعة القيوم،

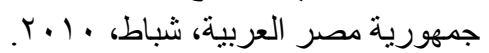

(20) Gould, Chery. Searching Smart On the World Wide Web : Tools and Techniques For Getting Quality Results. Berkley, California: Library Solutions Press, 1998. P 11.

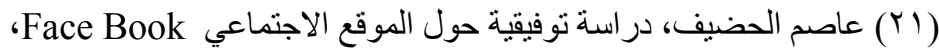
http://www.facebook.com/note.php?note_id=136415406384426

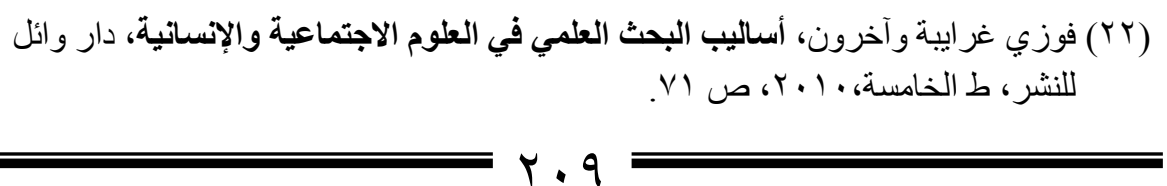




$$
\begin{aligned}
& \text { (YT) عاطف عدلي العبد، المنهج العلمي في البحوث الإعلاميـة، القاهرة، دار الهاني للطباعـة، } \\
& \text { rV } 1999 \\
& \text { (Y (Y) محمد منير حجاب، أساسيات البحوث الإعلامية والاجتماعية، دار الفجر للنشر التوزيع، }
\end{aligned}
$$

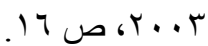

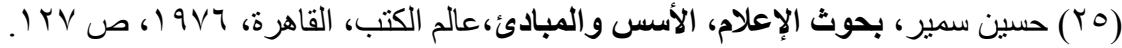

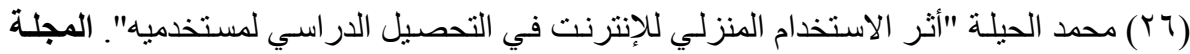

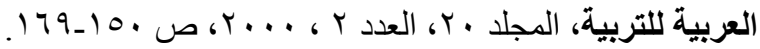

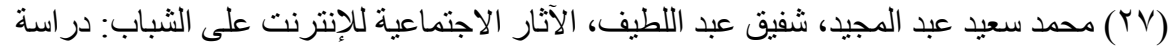

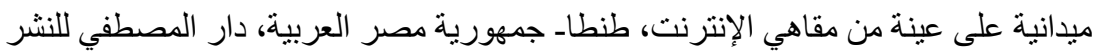

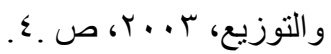

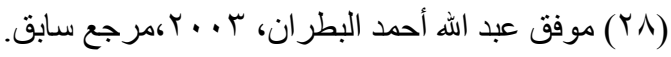

(29) University of Wisconsin-Madison. Students computing survey 2003. Retrieved may 13 , 2004 from: www.doit.wisc.edu/about/research

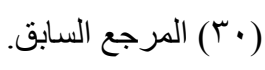

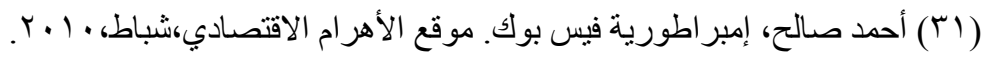
http://ik.ahram.org.eg/IK/Ahram/2011/2/28/INVE1.HTM

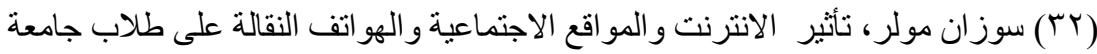

$$
\begin{aligned}
& \text { مير لاند في الو لايات المتحدة الأمريكية، }
\end{aligned}
$$

http://www.msnbc.msn.com/id/36742787/ns/technology_and_science-

$$
r \cdot 1 \cdot \text {./tech_and_gadgets }
$$

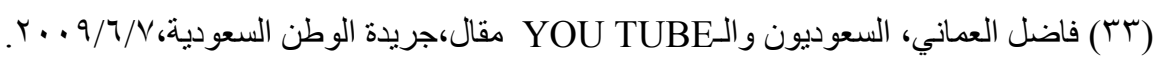
http://www.alfajer.org/index.php?act=artc\&id=1207

(؟ (ץ) عبد المجيد بو عزة، واقع استخدام شبكة الإنترنت من قبل طلبة جامعة السلطان قابوس، مجلة

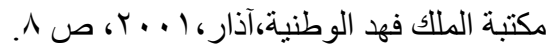

(35) University of Wisconsin-Madison. Students computing survey 2003. Retrieved may 13, 2004 from: www.doit.wisc.edu/about/research

(36) Tolpanen, Bradly P . a Survey of world wide web use by freshman English students : results and implications for bibliographic instruction.- Internet Reference Service Quarterly.- Vol. 4, No.4 (1999) - pp.45- 63 .

(37) Brian Murphy, and Andew Pascoe, op, cit' p210-211.

(38) PEW / Internet \& American Life Project, . op,cit. 
(39) Ferzetti, P.; Jaap, T.; King, T.; Tench, E. \& Thomas, J. op,cit., P.255.

(40) Nai, L. \& Kirkup, G. (2001). The Internet: producing or transforming culture and gender? Online: http://iet.open.ac.uk/pp/ G.E.Kirkup/Gasat .Html.

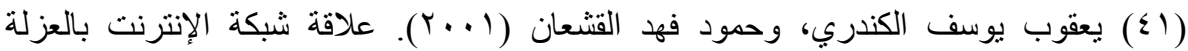

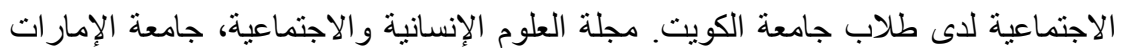

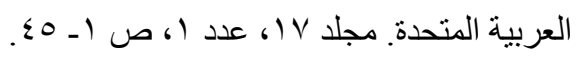

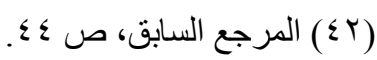

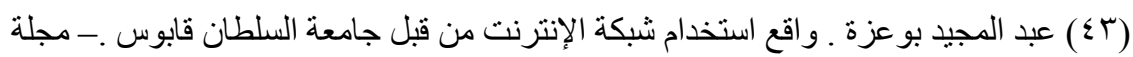

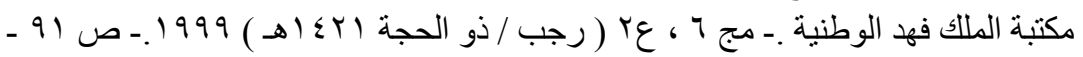

$$
\begin{aligned}
& .110 \\
& \text { ( ( §) خالد هانثم، التعليم العالي المعتمد على شبكة المعلومات الدولية (الانترنت) ، جزء ـ رسالة } \\
& \text { دكتور اه منشورة، WWW.mohyssin.com/form }
\end{aligned}
$$

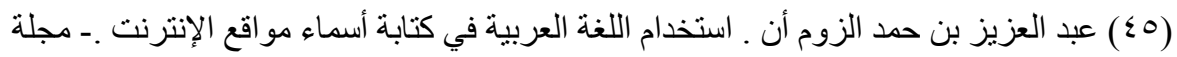

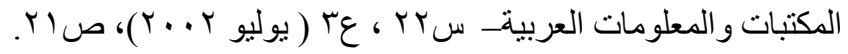

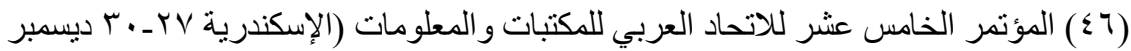

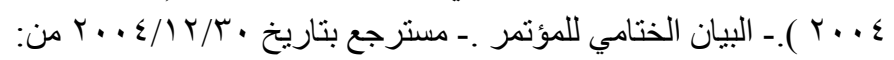

$$
\begin{aligned}
& \text {.www.cybrarans.info/conferences/ar/c17/htm }
\end{aligned}
$$$$
\text { (\&V) }
$$

(48) Duggan, A.; Hess, B.; Morgan, D and others, 1999, op, cit.

$$
\text { (9 ( ) ) تحسين منصور ، مرجع سابق. }
$$

(51) A. Durndell, \& Z. Haag, . Op. cit, (2002).

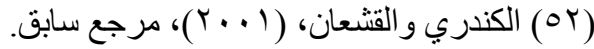

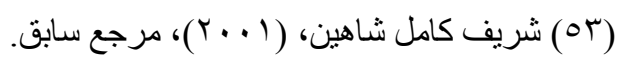

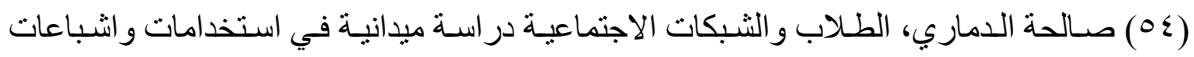

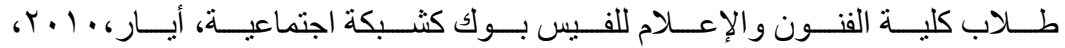

$$
\begin{aligned}
& \text {.http://alola.maktoobblog.com } \\
& \text { (00) عبير ابو طوق، إنكالات قانونية حول الدعاية الانتخابية المبكرة: مرشحي الفيس بوك ظاهرة }
\end{aligned}
$$

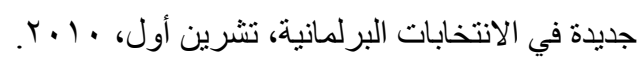


(56) Nigel ford, Dave miller, , op, cit,1997.

$$
\text { شريف كامل شاهين، مرجع سابق. }
$$

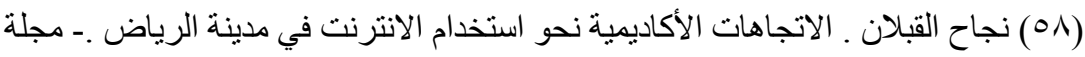

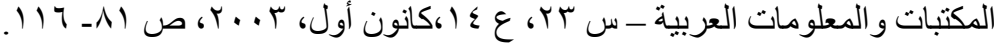

(09) موفق عبد الله أحمد البطران: واقع استخدام الإنترنت في الجامعات الأردنية الخاصة في منطقة

الثمال من وجهة نظر الطلبة واتجاهاتهم نحوها. رسـالة ماجستير (غير منشورة). جامعة الجاتية

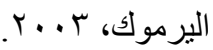

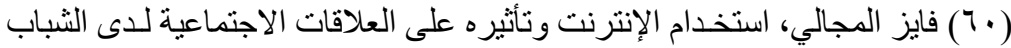

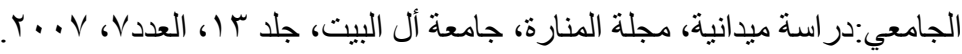

(ا7) عبد الرحمن حسين، أضر ار وفو ائد الانترنت على المجتمع الفلسطيني :

http://abdo2000.maktoobblog.com/

(62) Nai, L. \& Kirkup, G. (2001), op, cit.

(63) Nie and Erbing, op, cit, (2001). 